University of Rhode Island

DigitalCommons@URI

Open Access Master's Theses

1992

\title{
Bioremediation: A Developing Technology for Waste Management
}

Donna L. Lay

University of Rhode Island

Follow this and additional works at: https://digitalcommons.uri.edu/theses

\section{Recommended Citation}

Lay, Donna L., "Bioremediation: A Developing Technology for Waste Management" (1992). Open Access Master's Theses. Paper 745.

https://digitalcommons.uri.edu/theses/745

This Thesis is brought to you for free and open access by DigitalCommons@URI. It has been accepted for inclusion in Open Access Master's Theses by an authorized administrator of DigitalCommons@URI. For more information, please contact digitalcommons-group@uri.edu. 
BY

DONNA L. LAY

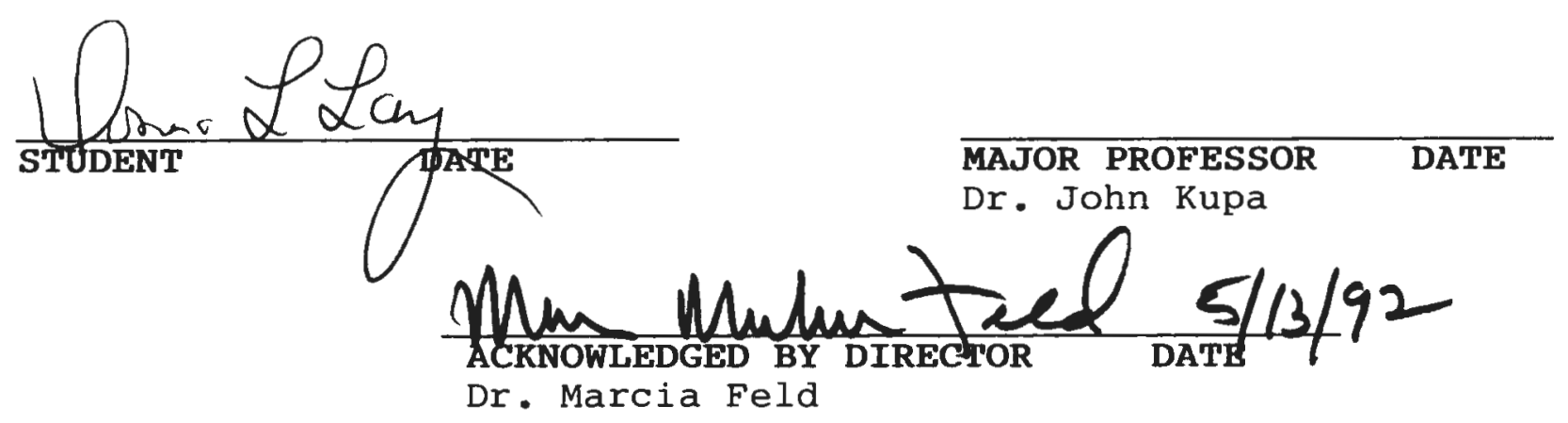

A RESEARCH PROJECT SUBMITTED IN

PARTIAL FULFILLMENT OF THE REQUIREMENTS

FOR THE DEGREE AND MASTER OF

COMMUNITY PLANNING

UNIVERSITY OF RHODE ISLAND

1992 
BIOREMEDIATION :

A DEVELOPING TECHNOLOGY FOR WASTE MANAGEMENT

I. Introduction

A. Definition of Bioremediation

1. Microbial processes

2. Types of microbes

B. Process of Bioremediation

1. Soil samples (identification of contaminants)

2. Identification of effective microbes

3. Reproduction of microbes

4. Treatment of contaminated area

5. Monitoring of contaminated area

C. Effectiveness of Bioremediation (case studies)

1. River Trent study

2. Exxon Valdez oil spill

3. Selenium cleanup with fungus

II. Waste Management

A. Definition of Waste Management

B. Current Technologies

1. Incineration

2. Landfilling

3. Recycling

III. Impacts of Bioremediation

A. Benefits and Future Uses of Bioremediation

B. Disadvantages of Bioremediation

C. Potential Abuses of Technology

IV. Conclusion

A. Recommendations

1. Waste management planning

2. Public policy/education

3. Research and development

B. Summary 
I. INTRODUCTION

Definition of Bioremediation................... 2

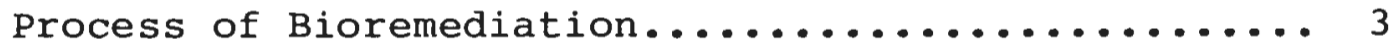

Effectiveness of Bioremediation................ 6

II. WASTE MANAGEMENT

Definition of Waste Management................. 12

Current Technology........................... 13

III. IMPACTS OF BIOREMEDIATION

Benefits and Future Uses of Bioremediation......... 24

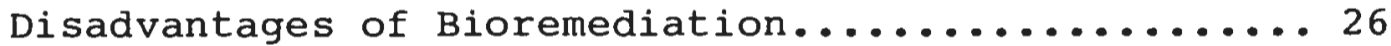

Potential Abuses of Technology ................. 28

IV. CONCLUSION

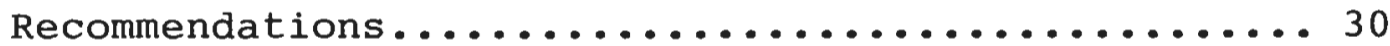

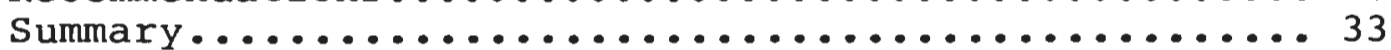

V. TECHNICAL APPENDIX 


\section{Introduction}

The existing crisis of waste management is not just an issue for environmental activists and environmental planners but it is also important to politicians, policy makers, community and urban planners. Without the combination of their expertise no solutions will be found for the pollution problems plaguing the world today.

This paper will discuss a technology which has been used in Europe for many years but is only now being researched in the United States. Bioremediation may not be the panacea to all pollution problems but its many benefits should be examined along with current waste management practices; landfilling, incineration and recycling.

Bioremediation and recycling are both under utilized technologies and there is a definite need for these nondestructive types of solutions. Both of these technologies have the benefit of not trading one source of pollution for another.

"Microbes given encouragement can do most of the reclamation work for us." 1 This philosophy has been used in experiments involving the purification of contaminated bodies of water such as lakes and rivers. This principal of microbial degradation should be extended to include contaminated soil, landfills, old quarries, gravel pits and many other previously unusable areas. 


\section{DEFINITION OF BIOREMEDIATION}

Bioremediation is the process by which microbes are used to eliminate contaminants by ingestion and degradation. These microbes are indigenous to the contaminated area and are non pathogenic. 2

The most commonly used microbes are aerobic microbes since the are very effective and easier to isolate and control during the process of biodegradation. The only disadvantage to aerobic microbes is that as depth of soil increases the amount of oxygen decreases limiting their effectiveness and the microbe's chance for survival. With aeration, water, and nutrients added these microbes will continue to degrade the contaminants. 3

Providing additional nutrients and oxygen is accomplished by using closed loop systems to circulate oxygen and nutrient enriched water through the saturated and unsaturated subsurface. The resulting increase in degradation rate and decreasing contaminant concentration is dramatic. 4

Bacteria, Actinomycetes, fungi, and algae naturally present in soil are all common in bioremediation. Yeast are occasionally used, which are larger than bacteria, and emit a more pleasant aroma in the degradation process. They are more commonly used in various fermentation processes in food production. 5 


\section{PROCESS OF BIOREMEDIATION}

To obtain the correct clean up microbes, scientists take soil or water samples from the contaminated site. The microbiologists breed strains that depend on a contaminant to live and which will die off when the food source (the contaminant) is gone.

One of the quickest ways to treat contaminated soil is to excavate it, mix it up with water, nutrients, and bacteria on a plastic sheet and pump air through it. Groundwater contaminated with oil, chemicals or other substances can be treated in a bioreactor, a tank containing specially selected microorganisms.

There are several problems associated with the process of bioremediation. Bacteria often take longer to remove contaminants from soil than the process of excavation and trucking of contaminated soil to landfills. Microbes often stop degrading the contaminant before it is eliminated, due to lack of oxygen and nutrients. Another drawback is that microbes can usually only attack one contaminant at a time. This is a problem for sites contaminated by more than one toxin. Scientists are researching genetically engineered organisms for these sites, but all of these microbes must undergo strict scrutiny by state and federal regulators. 6

Before bioremediation can be used on a site the history of the site must be fully researched for information 
concerning past uses (industrial, commercial, or residential) to search for all possible contaminants. Two studies performed include a microbial profile which includes a count of all indigenous microbes on the site and a feasibility study to determine whether bioremediation is the best solution to the cleanup of the contaminated site.

Microbes are extracted from samples taken at the contaminated site. Next the microbes which break down the contaminant(s) naturally are isolated. The amount of these indigenous microbes are then increased through the addition of fertilizers, water and aeration or by the reproduction of these microbes in laboratories. When microbes are stored for a long time, they are kept with the contaminant for which they have been isolated to attack. For example the particular organism which breaks down hydrocarbons (oil and gas compounds) is stored within a gas and oil mixture so it won't lose its attraction for these contaminants. If the ricrobes are synthesized in laboratories they can be applied to the contaminated site through injection, spraying, gravity drip or mixing into the soil. 7

Juring the degradation process, the soil has no prevalent odor, but out of soil the microbe and water mixture is pungent in odor. The soil during this process is harmless, since non pathogenic organisms are used. 
This process speeds up the natural degradation, caused by indigenous microbes in soil, from a 40 year cycle to a 90-150 day cycle of contaminated to clean soil.

Biostabilization is the process following the introduction of the microbes into the contaminated soil and involves the feeding of the organisms with fertilizers, continuous irrigation and aeration. This process enables the microbes to continue to ingest and degrade the contaminant. Once the contaminant has been degraded the amount of microbes is reduced to the amount naturally found in the soil. Periodic monitoring of the cleaned site is necessary to ensure the complete eradication of the contaminant. 8

Bioremediation can be performed in situ, above ground, or in specially constructed in ground cells. The key to in situ bioremediation is the transportation of oxygen and nutrients to contaminated areas. Since normal ground water flows from 10 to 200 feet per year nutrients could take years to traverse a small site. By increasing the gradient through pumping (draw down) and injection (mounding), transport times are reduced from years to weeks and days. 9

If soils are too impermeable for in situ transport of nutrients and oxygen, other on site treatment options may be used such as oxidation or excavation of soil in situ or above ground. Above ground treatment is not 
as desirable due to increased cost. In situ processes are less expensive and therefore preferred. ${ }^{10}$ (Refer to the Technical Appendix for more information on in situ microbial treatment of contaminated soil as provided by Affordable Technology, Inc.)

\section{EFFECTIVENESS OF BIOREMEDIATION}

Currently the Trent River in Great Britain is considered to be an unpurifiable water source due to pollutants caused by heavy industries such as coal mining. Researchers have conducted trials to see the effectiveness of microbes on "unpurifiable" waters such as the Trent using artificial lakes, such as the one located in an abandoned gravel pit at Lea Marton. This gravel pit was flooded with river water which was then siphoned through (3) large settling tanks. Cloudy water ran to a depth of 2 meters in the pit and there was no artificial stirring or agitation.

Naturally occurring microbes began to break down phenols and other poisonous chemicals. Soon algae appeared (on sunny afternoons) which bloomed. Within months, as the water was purified, crustaceans, water fleas (Daphnia), Beetles, fly larvae, and other aquatic creatures began to increase in numbers. 11

During the first year a stable community had evolved; fungi and bacteria were disposing of chemicals while taking 
in the past through the sinking of the oil with ash or sand. 13

Due to the problems associated with traditional methods of oil spill cleanup, bioremediation has become a popular alternative. Microbes break down the smaller oil molecules easily but as the size of molecule increases degradation becomes more difficult and takes a longer period of time for microbes to break these molecules down. 14

"Just after midnight on March 24, 1989, the Exxon Valdez super tanker ran aground in Alaska's Prince William Sound, spilling 10.1 million gallons of crude oil fouling 368 miles of shore line in the sound alone." 15 The Environmental Protection Agency enlisted the help of microbiologists and a new technique called Bioremediation to aid in the breakdown of the crude oil. Six oil stained beach plots were chosen and treated with nitrogen and phosphorus fertilizers to stimulate the naturally occurring bacteria to continue the natural degradation of the oil. Detected in these beach areas were air breathing bacteria (aerobes) with the ability to break down slowly volatizing alkanes and simple aromatic hydrocarbons.

The first 90 days tests compared two nutrient formulations created to help increase the indigenous bacteria's growth and rate of reproduction. One formulation incorporated oleic acid (best known as the primary fatty acid in olive oil). Researchers think this fatty acid 
could glue the mixed in bacterial nutrients to any crude oil on which they're sprayed.

The second nutrient formula is an off-the-shelf fertilizer "brickette". These brickettes are packed into biodegradable plastic sacks and are tied to pipes anchored to the beach. Tidal action during the test period should flush the dissolving fertilizer back and forth across the shoreline rock and sand. 16

There are drawbacks to using fertilizers, such as potential risks to sea life, especially where tidal flushing is minimal. The most seriously affected sea life would be the larvae of sea urchins, oysters and mussels. Environmental Protection Agency officials say it could take 5-7 years for the Prince William Sound area to naturally return to its former "pristine" state. This natural process could be increased with fertilizers and reduce contaminant degradation to $2-5$ years. ${ }^{17}$ (For more information on the use of bioremediation to cleanup the Prince William Sound area refer to the Technical Appendix.)

Bioremediation has also been shown to have an effect on Selenium contamination. Selenium has severely contaminated the vegetation and soil of the 1,000 acre Kesterson National Wildlife Refuge in Central California. According to state officials the only feasible solution is to bulldoze off a 6" layer of top soil from the 
contaminated area and dump it into a plastic lined 45 acre landfill. Researchers William Frankenberger and Ulrich Karlson (University of $C A$, Riverside) have found that fungus indigenous to the site have been naturally converting Selenium into a gas which is dispersed quickly into the air. The fungi do this for their own survival, to prevent Selenium from reaching lethal doses in the soil. Frankenberger and Karlson have created a hospitable environment for the fungi to encourage increasing growth therefore increasing the speed of biodegradation.

Another common wood rotting fungus may perform a similar job in treating waste water from chemical plants. The enzymes that allow these fungi to breakdown lignin (the chemical that holds wood fibers together), may also digest some hazardous and decay resistant pollutants. Microbiologist Dunja Grbic-Galic of Stanford University also recently demonstrated a type of bacteria which can be cultivated for the purpose of cleaning soil and groundwater contaminated with trichloroethylene, a widely used industrial solvent. 18 (Refer to the article "Toxic Wastes? A Little Fungus May Help" in the Technical Appendix for more information on the effect of fungus on selenium and trichlorethylene contaminated sites .)

The Rhine River in Germany is another heavily polluted water body currently being researched for the 
effectiveness of bioremediation. These polluted waters are allowed to run into lakes where they are naturally undergoing bioremedial processes through indigenous microbes. Eventually, these waters would be rejuvenated if not for the continuous flow of contaminants into them. To speed the process of pollutant degradation, contaminants are removed by chemical oxidation (in small portions) and by bioremediation. 19 (For more examples of the effectivness of in situ bioremediation on other contaminants refer to the Technical Appendix.) 
II. Waste Management

\section{DEFINITION OF WASTE MANAGEMENT}

The Resource Conservation and Recovery Act (RCRA) which was passed in 1976 defines solid waste as including garbage, refuse, sludge, solids and liquids from industrial, commercial, mining, agriculture, and community activities but excluding solid or dissolved material in domestic sewage. 20 World-wide urban residents produce between 1 and 4 pounds of solid waste per person per day. The United States generates at least 140 million tons per year, 80 percent of which is landfilled. In 1978 there were approximately 20,000 landfills in the United States. Now there are only 6,000 and by the year 1993 it has been determined that 2,000 more of these landfills will reach their capacity and close. 21

To manage the growing volume of solid waste, a combination of waste reduction, recycling, composting, use of landfills, incineration and bioremediation will be needed. 22 To develop a solid waste management plan, a planning commission or some other appointed committee should define its objectives clearly. 23 The objectives should include the amount of waste to be handled by each waste disposal option, disposal method of priority (recycling or incineration), and the implementation of the plan. 24 
Once the objectives of the waste management plan have been identified all pertinent information must be gathered and reviewed. All existing methods must be evaluated for effectiveness. The evaluation should take into account current practices within the community, the capacity, the remaining useful life and the budget of each disposal facility. The final part of the waste management plan should describe projected growth patterns for the community and the effect a future increase in population could have on existing waste disposal facilities. 25

\section{CURRENT TECHNOLOGY}

Incineration is the generation of energy from waste. 26 These waste to energy burners which are also called resource recovery plants, use solid waste as fuel to produce nearly 35 million watts of electricity and reduce garbage to ash in the process. Supposedly, these plants should be able to pay for their operation with money from tipping fees charged to garbage haulers and fees received from the sale of electricity. 27

Unfortunately, this technology allows the introduction of natural and artificial gaseous and particulate contaminants into the atmosphere, thus creating the dilemma of trading one source of pollution for another. 28 These pollutants range from heavy metals to acid gases to dioxins. 29 The ash remaining from the incineration process 
is also a concern due to the high ratio of toxic metals to harmless substances which makes this residue a hazardous waste. 30

Most communities had turned to landfill dumping in the 1950's and 1960's, but there were some incinerators still operating. These older incinerators still in use were responsible for disposing of about 10 percent of the waste stream during that period. The 1967 Air Quality Act placed stricter regulations on incinerator emissions increasing the need for the addition of expensive air pollution controls. The added devices increased the cost of operating incinerators to the point where the costs outweighed the benefits. 31

With the incineration industry declining, public officials and others concerned with the growing problems of solid waste management and disposal once again sought new technology from Europe. One of these new technologies was to serve as a model for restructuring the American incineration industry. This model, an electricity generating system, referred to as the water wall combustion unit had been used in Europe for more than 15 years. 32 By the mid 1970's several mass burn systems had been built and others were in the planning or construction phases. During this period of time three other technologies emerged which competed with the mass burn incinerators. 33 
The small modular combustion system is used in industrial, large retail and commercial complexes and apartment houses. 34 These mass fired furnaces require the shortest construction time and have the lowest capital costs, therefore having the greatest number of domestic installations of all incineration technologies. 35 Unfortunately one drawback to this incineration method is that modular furnaces are less thermally efficient due to high excess air requirements, high radiant heat loss, and a high percentage of unburned char in residue. These units are not often used to produce high pressure and temperature steam desired for efficient cogeneration of electric power with steam and heated water. 36 Heat recovery units are added to these systems to allow recovery of energy either as hot water, steam or hot air. 37

Another incineration system is based on the Pyrolysis method which involves an endothermic (heat absorbing) process rather than an exothermic (heat generating) process. The endothermic reaction occurs when organic material in the waste is exposed to heat in the absence or near absence of oxygen. Heat is then recovered as energy by the transformation of the solid waste into steam or a gaseous or liquid fuel. 38

The third system which competes with the mass burn incineration process is called the refuse derived fuel 
method (RDF). This method involves the shredding and / or separation of waste to reduce particle size and remove certain components of the waste stream such as ferrous metals. The more combustible fraction of the waste is ground into dense, pellet-like units suitable as fuel in a stoker feed fuel burning system such as those using coal. The RDF technology is effective both as a method of waste disposal and in providing a fuel supplement for other electricity generating systems. 39

Regardless of combustion technology, resource recovery facilities produce steam or hot water, electricity or a combination of the two called cogeneration. Steam can be used for heating and cooling systems, industrial thermal processes, or mechanical driven power. Hot water can be used for heating and cooling systems and lower temperature industrial thermal processes. 40

Electrical energy can be used in the facility itself, sold to local utility companies or nearby industries, or sent to other utilities. The electricity is produced by passing steam produced in the incinerator's boiler system through a turbine generator. The steam turbine's rotary motion turns a generator to produce the electricity. 41 The late 1970's became a time of crisis in waste management as landfills began to be filled to capacity and incinerators with their high costs and constant 
breakdowns did not meet expectations for their effectiveness. Even with the stricter air quality standards the need for incineration continued to increase. Resource recovery plants were being promoted as energy suppliers rather than as garbage burners. 42

By 1980 sixty plants were either on line, proposed, or under construction throughout the United States. Many municipalities began to move toward incineration. Within five years there were approximately 200 incinerator plants built or under construction. The increased interest in waste to energy technology spread throughout the country, forty four (44) out of fifty (50) states had at least one facility planned or under construction.

As of the late 1980's the United States was spending approximately $\$ 17$ billion on the incineration industry. During this time period experts began to consider incineration risky and a potential problem maker. They felt that incineration was simply trading one pollution source for another. 44

Despite decades of failures and costly repairs, incinerators are still a popular alternative to landfilling. One study estimates that by 1992115 new plants will open. Incinerators built today are costing an average of over $\$ 200$ million. This cost is being absorbed by taxpayers through taxes on garbage disposal. 45 
There are several differences between the incineration technology of Europe and the United States. The differences may explain why there are fewer problems with European incinerator plants. In Europe, garbage burned consists of different products which are less damaging to the incinerator plant. American garbage produces substances that cause more corrosion due to the higher temperatures needed to generate electricity. The product of the smaller European incinerator is steam rather than electricity. Another difference in the incineration technology is that in Europe there is no sorting of garbage before burning. 46 European incineration industry requires daily reportings of air pollution emissions from every incinerator whereas American operators are allowed to continue burning garbage with very little if any regulations on emissions.

As for health risks, the EPA has estimated the increase in cancer due to incinerators will be 4 to 60 cases nationwide annually once the 200 proposed plants are opened by 1992. The EPA has not estimated health risks caused by other methods of exposure such as absorption of contaminants through skin and ingestion of contaminated food.

A Newsday survey of 56 states and territories has revealed that more than 2,000 landfills have been closed since 1982 for environmental reasons and another 700 have 
closed after reaching capacity. With an approximate 230 million tons of garbage produced per year these closures have ensured an increasing problem of burial of garbage and have forced scientists, public officials and others to look for other methods of waste disposal. 47 According to the Environmental Protection Agency, within 8 years more than one half of all of America's landfills will reach their capacity. 48

As landfills are closed on the east coast, cities are transporting their garbage west at tremendous costs to taxpayers and are spreading pollution rather than eliminating it. One of the worst problems in the trucking of waste products is the lack of regulation. Trucks which haul garbage to the midwest from the east coast are allowed to return with perishable goods for consumers.

Even though truckers say they sanitize their trucks between hauls, health officials warn that waste being carted can carry infectious diseases not easily eliminated from the trucks. One of the only ways to ensure proper cleansing of these trucks is steam cleaning which is both timely and expensive therefore it is seldom utilized by truckers between hauls. 49 "As legal disposal grows more difficult, some private waste haulers simply unload their fetid cargo anywhere, from ghetto streets to forests." 50 
To minimize the problems of landfills there are several practices that should be enforced. Landfills should not be located over groundwater recharge areas especially where groundwater serves as a source of drinking water. New landfills should be lined with a synthetic material and two layers of clay which minimizes movement of contaminated water through and out of the landfill into the surrounding groundwater. Contaminated water should be collected in pipes and drawn into treatment areas. Another practice which can minimize water contamination caused by landfills is the continuous monitoring of groundwater in test wells. Air pollution can be limited by the installation of a system which recovers methane. 51

Unfortunately for all alternatives mentioned, none will replace the need for landfills. They will continue to be necessary for materials which can not be recycled and for the ash produced during incineration. Any new technology such as bioremediation is therefore important because it will be able to reduce the burden on landfills. Microbes degrade the contaminants in soil leached from landfills and reduce the amount of waste in the landfill thereby solving two problems associated with landfilling. 52

Since 1960 the amount of packaging in garbage has increased 808 and now makes up one third of the waste stream 
in America. Unfortunately $30-408$ of the waste stream today is not recyclable and will cause problems in landfills. 53 Recycling is a means of reworking a specific product, for example paper is reprocessed as paper and plastics into plastics. 54

Waste reduction programs can help lessen the burden on landfills and incinerators. Glass, aluminum, and iron do not burn when put in incinerators thus they lessen its efficiency by lowering the temperature and causing the production of more toxic materials in the leftover ash. This toxic ash has caused many problems in disposal especially where leaching can occur from landfills. 55

One of the advantages that recycling has over incineration is in the production of energy. Incineration produces 500 BTU's steam from $1 \mathrm{lb}$. of paper whereas recycling that same $1 \mathrm{~b}$. of paper conserves 2,000 BTU's in energy required to produce paper from virgin pulp. 56 Another incentive to recycling is the reduction in the amount of garbage that has to be incinerated or landfilled. Observing other countries such as Japan where recycling is widespread reinforces this idea. While garbage production is on the rise in the United States, Japan has actually maintained a constant level of production from 1976 through 1986. Residents of Japan recycle an estimated $50 \%$ of their wastes. Education is a key factor, each year 
Japan's officials explain to residents the recycling program and its' benefits.

Unfortunately there are also many roadblocks to the recycling process. The United States government has not committed sufficient money or people to the recycling industry. In comparison approximately $\$ 305$ million was spent on promoting the incineration industry whereas only $\$ 8$ million was spent on promoting recycling. The American people are not enthused with the idea of recycling and many complain that there is too much extra work. Education programs for the public are necessary to make recycling a simpler and a less grueling process. Communities must be shown the benefits of recycling in comparison to other methods of waste disposal.

Another reason recycling has not become popular is that the economy has been slow to adjust to the reuse of household trash. Radical swings in prices paid for materials from natural resources and the products from recycling have discouraged some recycling programs. Incentive is also down due to the increasing need for paper refuse by the incineration industry. ${ }^{58}$ A major problem with the recycling industry is that it is not a supply driven business. 59

Aluminum recycling is more promising than plastics and paper. The production of sheet aluminum for new cans 
from old cans consumes less energy and is cheaper due to an effective and efficient system which separates the aluminum from the solid waste stream. There will always be a market for recycled aluminum. 60 The American Iron and Steel Institute estimates that about two-thirds of the scrap steel in the United States is recycled and most of that comes from junk cars and used appliances.

61 
III. Impacts of Bioremediation

\section{BENEFITS AND FUTURE USES OF BIOREMEDIATION}

The Environmental Protection Agency estimates that the cleanup of 1,200 superfund sites (areas of extreme contamination) throughout the United states would cost an estimated $\$ 24$ billion, using technologies currently available. These technologies include incineration of contaminated soil which can run up to $\$ 1,000$ per ton.

By contrast the process of bioremediation typically costs less than $\$ 100$ per ton and offers the big advantage of restoring land and water thought to be unusable due to being polluted. Microbes have the ablility to ingest and destroy the contaminants without leaving any toxic residue behind unlike other waste processing technologies such as incineration. 62

Microbial treatment of contaminated soil can remove the burdens of incineration and landfilling. Most naturally occurring compounds and many synthetic compounds, Xenobiotics, can be eliminated by microbes. 63 Bioremediation has already been shown to significantly reduce the amount of pollution caused by large oil tanker spills such as the Exxon Valdez disaster. This technology is needed in such cases to reduce the cleanup time of oil spills and the negative impacts to plant and animal life caused 
by the harsh detergents used in traditional cleaning methods. (See the Technical Appendix for other uses and benefits of bioremediation.)

Currently Americans generate approximately 160 million tons of garbage per year. 64 The landfill and incineration technologies together can barely meet the need for waste management at present and each year the amount of garbage produced by Americans will continue to increase. Bioremediation may be able to solve not only the problems of land reclamation but also the crisis of solid waste management.

Researcher William Rathje, of the University of Arizona in Tucson, has found that biodegredation does not significantly occur at present in landfills. Under normal conditions in the landfill the lack of nutrients and aeration significantly affect the efficiency of microbes in the landfill. 65 The process of bioremediation involves the addition of larger amounts of these biodegrading microbes, aeration, and fertilizers thus increasing the effectiveness of the degradation process causing a faster breakdown of the mounds of waste overflowing the landfills. Bioremedation also has the benefit of reducing waste without introducing another source of pollution such as ash and other toxic residues into the environment. 
Bioremediation could also play an important part in the cleanup of oil spills from leaking underground storage tanks. As states become increasingly aware of the contamination caused by older storage tanks to soil and ground water, they are requiring environmental assessments of areas containing these tanks.

In Connecticut tank removal and excavation companies are gaining business as state regulations governing underground storage tanks become stricter. This is especially true of older gasoline stations undergoing renovations and / or sale. The tanks and soils surrounding these tanks are tested for leaching contaminants. If any evidence is found of leakage the tanks must be excavated and removed. The contaminated soil is then carted to a landfill. New soil is carted in and new tanks replace the old ones.

The major problem with tank removals is the process of carting contaminated soil to the landfill which has the potential of contaminating ground water if it should leach from the landfill. Treating the soil on site with microbes may take longer than carting it away but bioremediation is cheaper and eliminates the problem of future soil and ground water contamination. 


\section{DISADVANTAGES OF BIOREMEDIATION}

There are a few disadvantages of bioremediation including length of degradation time and effectiveness of microbes. Even under ideal conditions the process of bioremediation takes longer than excavating and carting the contaminated area to a landfill. Environmental companies under contract deadlines may choose faster methods of waste disposal even if they are shorter term solutions. Another problem with bioremediation is that there are many variables affecting each contaminated site therefore they will not all respond to microbial treatment in the same manner. Since there so many unknown variables including millions of different microbes which are affecting the contaminant(s) on the site it is not easy to isolate one microbe which will perform the degradation the most efficiently.

It can be very time consuming identifying the proper microbes to use on a contaminated site especially if there are multiple pollutants involved. To keep the microbes degrading the contaminant(s), continuous monitoring is required. The monitoring of the site shows if the microbes are functioning efficiently and whether or not additional nutrients (air, water and fertilizers) will be needed.

Unfortunately as in any new technology, there are no definites as to how long the process will take or how 
effective it will be. Bioremediation is still an evolving technology and as such it can not be relied on as the sole answer to the waste management crisis facing our world today.

\section{POTENTIAL ABUSES OF TECHNOLOGY}

With all the benefits of Bioremediation there is also potential for misuse and abuse of this technology. As people find it easier and cheaper to use this method of cleanup there could be a tendancy to continue to pollute and contaminate the earth's natural resources at the same rate as present. If the public is not educated properly about this technology it may be used as a panacea for all the world's pollution problems. Bioremediation has many benefits over other methods of waste management and reduction but it is most effective when used along with other technologies.

One country which utilizes all methods of solid waste management fairly efficiently is Japan. Unlike the United States, the Japanese realize that burning, burying, recycling and reducing are all important parts of solid waste management. Of all these methods though, recycling is the solution of choice in Japan. Approximately 408 of their solid waste is recycled comprised of one half of the paper, 558 of glass bottles and 668 of food and beverage cans. 66 
Since the early 1970's officials in Japan have strictly enforced mandatory separation of burnable from noncombustible trash. To burn the combustible trash there are 1,899 refuse burning plants in Japan. This is one draw back to Japanese waste management since there are so many incinerators for a small country and few regulations governing their operation. The officials only monitor four types of emissions therefore there is increasing concern over air quality. 67

Like the United States, Japan has not completely conquered their garbage disposal problems. In Japan a major problem of public officials is keeping the incentive to recycle high. Even now little used appliances and furniture can be found in Japan's landfills. Another problem with Japanese society is that everything bought is wrapped in paper even a pencil. 68 Japan's obsession with wrapping everything is also an example of how technology can be abused. By not reducing the amount of waste produced Japan is only temporarily putting off their waste crisis. As long as they continue to wrap everything sold and discard barely used appliances their recycling and incineration programs will not reach their optimum efficiency. 


\section{Conclusion}

\section{RECOMMENDATIONS}

The public must be educated about each of these technologies their benefits and drawbacks. It is important for public officials, environmental planners and environmental activists to work together to present all waste management and reduction programs. There is a need to formulate a comprehensive plan concerning methods of waste management for the United States.

In a comprehensive plan; source reduction, recycling, landfilling, incineration and bioremediation need to be addressed as they are all important methods of disposal and management. Increasing public concern on problems associated with soil, water and land contamination, have caused increasing awareness leading to new reasearch in waste management planning.

There are several important steps in any management plan. First standards for quality (air, water, soil) must be set which represent a desirable or at least an acceptable level to the society affected. Next the existing quality must be determined by monitoring. Once this quality is known plans must be developed which include the standards set and a permitting process.

There are several important parts to creating a recycling plan which could help solve current problems 
with burying and burning waste as a component part of the overall waste management plan. Mandatory recycling plays an important part by increasing the participation by the public in any recycling program. With proper education, mandatory recycling programs throughout the United States have a 908 participation rate. Economic incentives to haulers and households is another method of soliciting participation in recycling programs. 69

One of the most effective methods of educating the public is through the public school system. Teaching younger people the values of recycling in school is important since as these children grow they will not only continue to practice what they have learned but will also pass on this information to other generations. 70

Another important part of the recycling plan is the need for local, state, and federal governments to buy products made with recycled materials. The Environmental Protection Agency and the United States Department of Commerce must purchase recycled products made in the United states to make its industry more competitive with other countries. Other economic incentives must be made to ensure the marketability of recycled materials especially to manufacturers. Some incentives for manufacturers are below market rate loans to encourage them to locate in a particular area and create markets for locally recovered 
materials. This scrap based manufacturing creates jobs and new skills, encourages investment and enlarges the manufacturing tax base of the local economy. 71

Each method of waste processing and disposal has a place in the waste management plan. Every technology available must be examined to help define the problems of waste management and each should be utilized to reach a solution to this environmental crisis. Incineration alone may not be the solution to a community's problems, especially if there is already concern over air quality in that area. That community may be better off adding a recycling program and utilizing bioremedial technology to reduce their landfills in size and to protect the surrounding soil and groundwater from leaching contaminants. Educational programs should be designed for all ages concerning the options of waste management. Public involvement can be crucial in finding solutions to problems which affect the whole community. As stated earlier in the recycling plan, school can provide an important median for training children the importance of waste management and their future lifestyles.

The government should take an active role in creating public information films, seminars, and booklets concerning the waste management crisis facing the United States and other countries today. Information highlighted should 
include summaries each waste processing and disposal option and any new technology such as bioremediation which is being researched.

The research and development of new technologies such as bioremediation should also be aided by the United States Government since waste management is a concern for the whole country. A national commission involving specialists on waste management should be developed which studies the pros and cons of current methods and potentials of new technology.

\section{SUMMARY}

The crisis of waste management has created an increase in public awareness. Unfortunately this awareness may be too late and the public has little knowledge of the impact their waste has had on the environment. Although there are several technologies practiced in waste management many of them create other types of pollution.

This paper has summarized the current technologies available in waste management and the potential uses of a newer method called Bioremediation. With increasing research this method can provide a solution to the waste management crisis if it is used in conjunction with current methods. Bioremediation is also an important method of land and water reclamation. Sites previously thought to 
be unpurifiable have the potential for reuse once they are treated with microbes. Bioremediation has been shown to be an effective method of decontamination without leaving any toxic residues.

Microbes used in this process die off as the pollutant is degraded and return to their normal population size. Once treatment of the site is complete, continuous monitoring is necessary to ensure that all traces of the contaminant have been eradicated.

of the current technologies recycling has been proven to be the most effective method of waste reduction and the least damaging to the environment. Landfilling and incineration have been shown to be the most damaging and have not created a solution to the waste management crisis. This paper has also attempted to explain waste management planning and the necessity of each method in such a plan. One method alone will not solve our waste disoposal problems. The key to the management plan is waste reduction, recycling, and incineration. New methods such as bioremediation are also important in the waste management plan since they will provide future alternatives to landfilling and incineration. Continued studies of new technology should be encouraged as supplemental methods of waste disposal and processing. They should not be sought as a substitute to existing 
methods until they are proven to be better then older technology. As new treatments are proposed, tested and proved reliable they can be integrated in the overall management scheme.

A solid plan for educating the public on waste management and methods should be of primary concern to any government agencies (state and federal) devising waste management plans. Proper education on the crisis existing today in waste management will help the public understand why cooperation in waste reduction and recycling programs is necessary.

Earlier education on waste management may also drive children to seek higher education and positions in environmental fields as they get older, thus ensuring new voices in the fight to save our environment. The sooner the public becomes aware of the growing problems associated with landfills, incinerators and other pollutant sources, the sooner a solution can be found to alleviate them. Although Bioremediation may not be the ultimate solution to the problems of waste management it is a step in the right direction. Instead of sitting and waiting for the environment to clean itself, scientists are testing the potential of microbes to do the reclamation work faster. From the shores of Prince William Sound, Alaska to the East Coast of the United States researchers are learning 
all they can about the microbes which inhabit our soils. Some enterprising scientists have already begun to market this technology on small sites in need of detoxification. Hopefully this technology will be effective on larger superfund sites throughout the United states. If this becomes a regular practice, billions of dollars saved in the cleanup of these site could be used to develop other methods of waste management. 
V. Technical Appendix 


\title{
IN SITU
}

\section{MICROBIAL TREATMENT}

\author{
OF
}

CONTAMINATED SOIL

(BIOREMEDIATION)

\author{
AFFORDABLE TECHNOLOGY, INC. \\ 3179 BABCOCK BOULEVARD \\ PITTSBURGH, PENNSYLVANIA 15237 \\ (412) 364-9005
}




\section{ATI Bioremediation, Inc.}

"Environmental Bioremediation" by ATI using state of the art technology.

Is bioremediation feasible at your pertoleum fuel contaminated site?

This question can be answered by an ATI microbial/soil profile (study). This profile includes:

- Isolation of natural soil microbes from the contaminated site.

- Identification of specific microbes, e.g. Pseudomonas species, that are resistant to and decompose the petroleum hydrocarbon.

Bacterial Growth Petroleum 1 Hydrocarbon test disk

Is it feasible to proceed? What do we need?

- If it is feasible ATI will provide a biomass (increase the population) of the identified petroleum hydrocarbon decomposing microbes.

a few

- selected

microbes

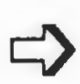

.

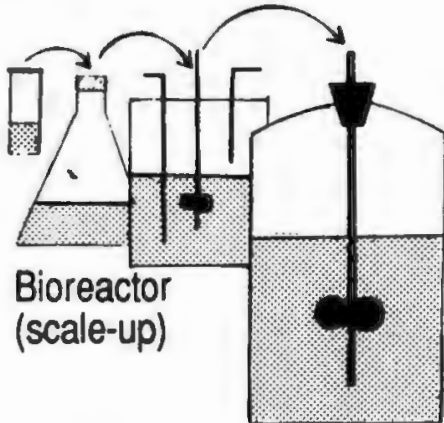

$\Rightarrow \quad$ trillions of

What is the next step?

- ATI will apply the biomass to the contaminated soil in situ using a gravity drip, injection or spray technology.

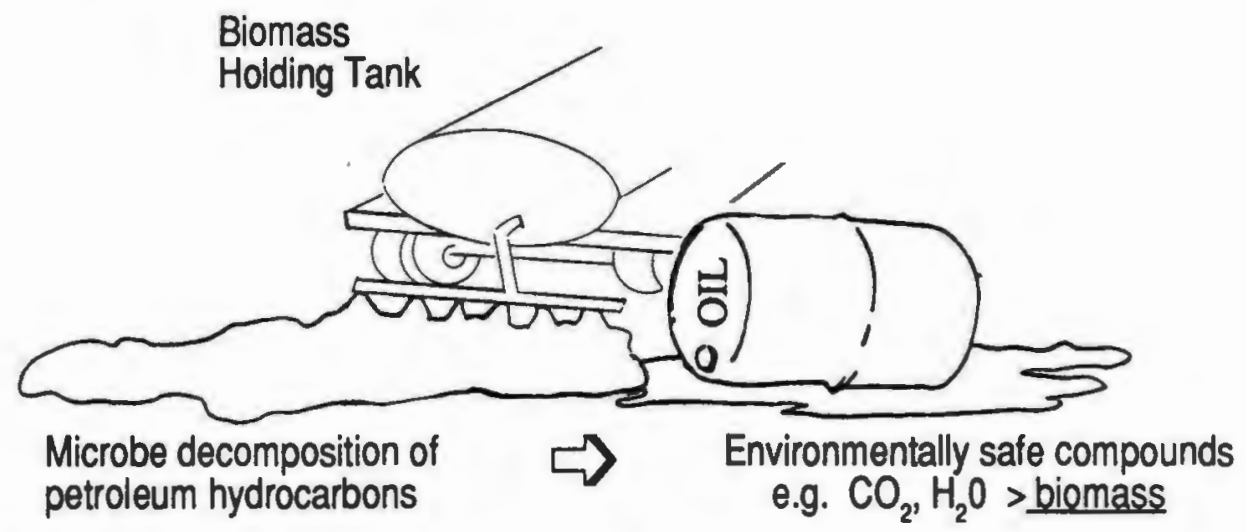

ATI Bioremediation efficiently eliminates petroleum hydrocarbon spills rapidly in situ (90 to 150 days) at low cost $\left(\$ 25\right.$ to $\left.\$ 85 / \mathrm{yd}^{3}\right)$ 


\section{AFFORDABLE TECHNOLOGY, INC.}

We have enclosed information on bioremediation technology that is being used to renew contaminated soil.

This process may be new to your firm, but it is state-ofthe-art technology that is being employed worldwide.

If interested, please contact us so that we may establish a time and date for our bioremediation presentation in order to interact with your firm regarding environmental remediation.

Respectfully submitted,

AFFORDABLE TECHNOLOGY, INC.

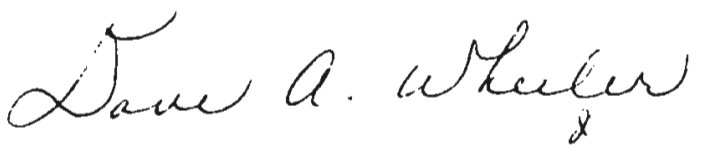

Dave A. Wheeler,

$\checkmark$ ice President

$D A W: j d s$

(enc.) 


\section{ENVIRONMENTAL BIOREMEDIATION}

Support for engineered "Environmental Remediation" by providing:

- Microbial profile (bioassay).

- Microbial candidates for specific chemical decomposition.

- Microbial BIOMASS for application to contaminated project site.

- Biostabilization chemicals.

- Bioremediation project sile monitoring.

- Pathogenic microbe isolationvidentification/inradication.

AFFORDABLE TECHNOLOGY, INC.

3179 Babcock Blvd. • Pittsburgh, PA 15237

(412) 364-9005 
AFFORDABLE ENVIRONMENTAL BIOREMEDIATION

We at AFFORDABLE TECHNOLOGY, INC., can expand your firms capable 1 ties into the world of bioremediation through microbiology.

AFFORDABLE TECHNOLOGY, INC., attacks your sol contamination problem efficiently and safely with naturally-selected microbes.

AFFORDABLE TECHNOLOGY, INC., microbial bioremediation services are competitive and in fact can provide large savings over incineration or off-site disposal of contaminated soil.

AFFORDABLE TECHNOLOGY, INC., provides your firm with technical consultation and bioremediation microorganisms to solve your soil contamination problem.

Should you be interested in information about our service, please drop us a line or give us a call at:

AFFORDABLE TECHNOLOGY, INC.

3179 Babcock Boulevard

Pittsburgh. Pennsylvania 15237

(4i2) 364-9005

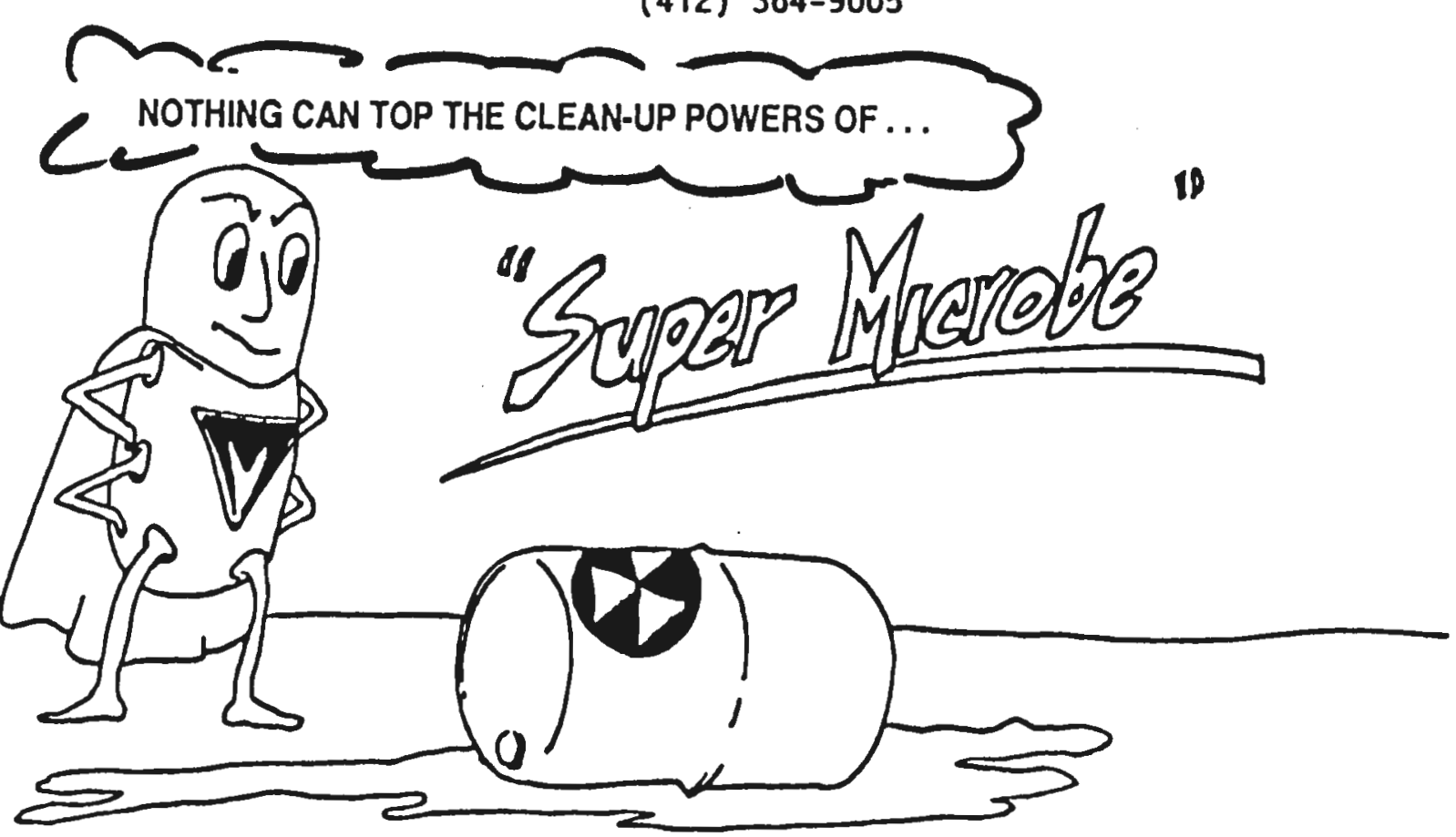




\section{SCOPE AND MAGNITUDE OF THE PROBLEM}

- APPROXIMATELY 10,000 MAJOR SITES NATIONWIDE REQUIRING RESTORATION - ESTIMATED 100 BILLION DOLLAR COST

- 400-800 DOD SITES - ESTIMATED 5-10 BILLION DOLLAR COST

- 32 MILITARY SITES ALREADY ON NATIONAL PRIORITIES LIST

- MULTITUDES OF PRIVATELY-OWNED RESIDENTIAL PROPERTIES CONTAMINATED WITH TOXIC WASTE 


\section{CURRENT TECHNOLOGIES}

- INC INERATION

- LAND-FILL

- AIR STRIPPING

- ADSORPTION

- BIODEGRADATION 


\title{
DISADVANTAGES OF FREQUENTLY USED CURRENT TECHNOLOGIES
}

- LANDFILLS

\begin{abstract}
A NON-PERMANENT SOLUTION FOR MANY HAZARDOUS WASTES AND THEREFORE, PRESENTS A FUTURE LIABILITY
\end{abstract}

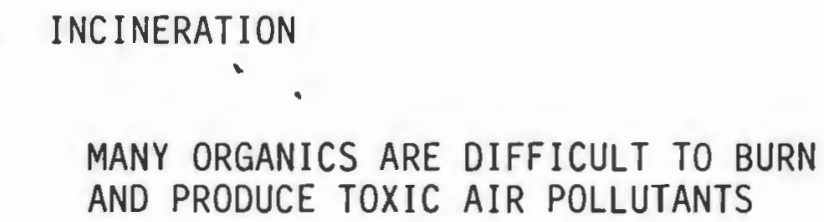




\section{BIODEGRADATION}

BIODEGRADATION IS THE USE OF MICROORGANISMS (BACTERIA, MOLDS, ALGAE) TO DEGRADE OR DETOXIFY HAZARDOUS CHEMICALS* THAT PERSIST IN THE ENVIRONMENT

*NATURAL (OCCURRING IN NATURE) OR XENOBIOTIC (SYNTHESIZED BY MAN, NEVER FOUND IN NATURE) 
STEPS IN ENVIRONMENTAL BIOREMEDIATION

1) HISTORY OF CONTAMINATED SITE

2) MICROBIAL PROFILE OF AREA

3) NATURAL SELECTION OF MICROBES THAT METABOLIZE CONTAMINATING CHEMICALS

4) QUANTITATIVE INCREASE OF SELECTED MICROBE ( $\Lambda$ FERMENTER PRODUCED BIOMASS)

5) APPLICATLON OF THE MICROBE BIOMUSS

TO THE CONTAMINATED SITE

6) BIOSTABILIZATION

7) PERIODIC MONITORING OF BIOREMEDIATION SITE 


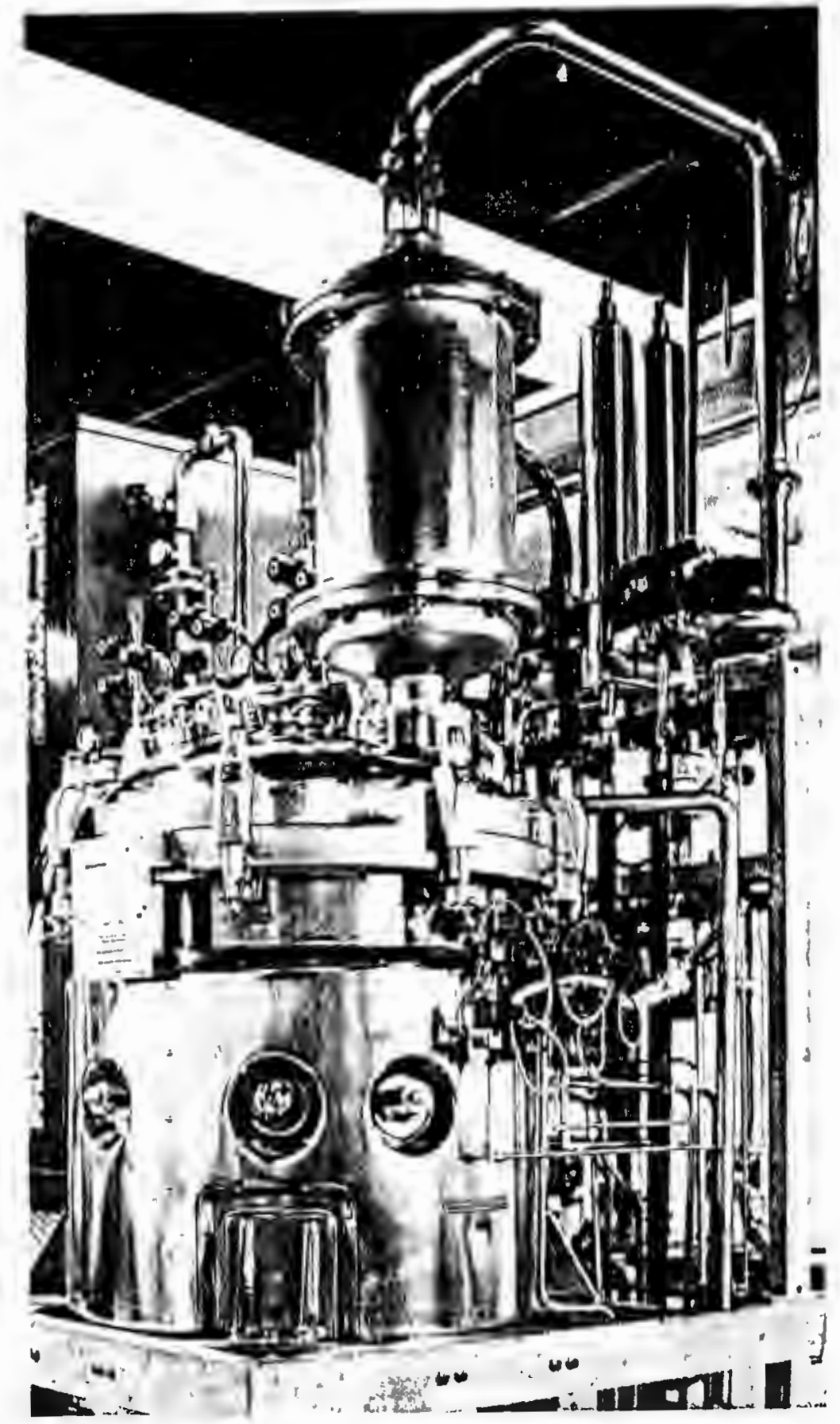

500 LITER COMPUTER CONTROLLED FERMENTATION SYSTEM USED TO PRODUCE OUR BIOMASS 
BIOSTABILIZATION PROVIDES:

- AERATION

- NITROGEN

- PHOSPHORUS

- tRACE ElEMENTS 


\section{ADVANTAGES OF BIODEGRADATION (BIOREMEDIATION)}

. NATURAL "LOW-TECH" SOLUTION

- PERMANENT SOLUTION TO PROBLEM

- may obViate neEd fOR exCAVATION

- NO RELEASE OF TOXIC EMISSIONS

- EFFECTIVE FOR DECOMPOSITION OF A VARIETY OF CONTAMINANTS IN MANY ENVIRONMENTS

- EASILY INTEGRATED WITH CONVENTIONAL PROCESSING 
ADDITIONAL "BIODEGRADATION" FACTS

- BIOREMEDIATION RESULTS IN DETOXIFICATION

- NATURAL COMPOUNDS ARE DEGRADABLE

- MANY XENOBIOTICS (MAN-MADE COMPOUNDS NOT FOUND IN NATURE) ARE DEGRADABLE

- HYDROCARBONS ARE PARTICULARLY SUSCEPTIBLE TO BIODEGRADATION

- MICROBES OF THE GENERA PSEUDOMONAS, NOCARDIA AND STREPTOMYCES DEGRADE HYDROCARBONS 
WHY AFFORDABLE TECHNOLOGY, INC., DOES NOT

EMPLOY GENETICALLY-ENGINEERED MICROBES

- mar convert to original genetic state

- NOT READILY CERTIFIED BY FEDERAL OR STATE GOVERNMENTS FOR USE

- DO NOT COMPETE WELL WITH NATURAL SOIL MICROORGANISMS

- may be haRMfUl to environMENT 
AT AFFORDABLE TECHNOLOGY, INC., WE

EMPLOY NATURAL-SELECTED SOIL MICROBES

THAT ARE TAILORED TO EACH PROJECT SITE 
ADVANTAGES OF NATURAL-SELECTED MICROBES

- THEY ARE DEPENDABLE FOR DECOMPOSING A SPECIFIC CHEMICAL

- DER/EPA ACCEPTABLE

- THEY COMPETE WELL WITH OTHER MICROBIAL FLORA

- ADJUSTEd to local ENVIRONMENTAL CONDITIONS

- THEY ARE NOT HARMFUL TO ENVIRONMENT

- SELF-LIMITING 


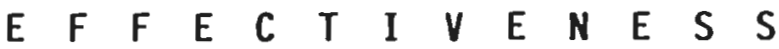

- BIOREMEDIATION OF HYDROCARBONS-CONTAMINATED SOIL RESULTS IN ACCEPTABLE LEVELS IN 90 TO 120 TREATMENT DAYS

- BIOREMEDIATION OF OTHER TOXIC SOIL CONTAMINANTS CAN RESULT IN A SATISFACTORY REDUCTION IN 120 TO 150 TREATMENT DAYS

- ENVIRONMENTAL BIOREMEDIATION CONTINUES EVEN AFTER ACTIVE TREATMENT OF CONTAMINATED SITE HAS ENDED 


\section{$\begin{array}{llll}C & 0 & S & T\end{array}$}

BIOREMEDIATION COST* OF SOIL WILL VARY FROM $\$ 20.00$ TO $\$ 80.00$ PER TON $(2,000$ LBS) DEPENDING ON THE SIZE AND VOLUME OF THE CONTAMINATED SITE.

*COST WILL BE CALCULATED ON A DIFFERENT SCHEDULE IN THE CASE OF A MULTI-CHEMICAL CONTAMINATED SITE. 


\title{
Aerobic Biodegradation of Vinyl Chloride in Groundwater Samples
}

\author{
JOHN W. DAVIS* AND CONSTANCE L. CARPENTER

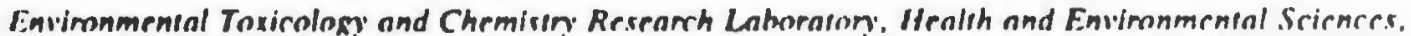

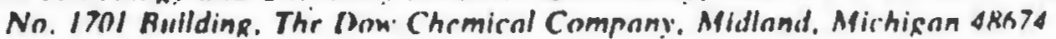

Rereived un Jily I0On'Accemed R Octoher I000

\begin{abstract}
Studis were enndurted to examise the bindegradation of "C.labeled rinyl chlorhde in cumples taken from

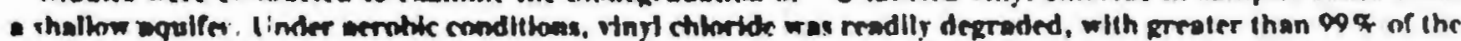

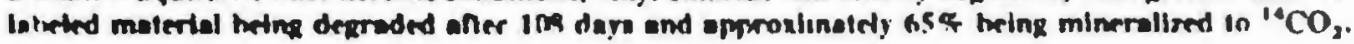

Widesprend lie of chlorinated sliphalic hydrocartxons has stimulated cunsiderable interest in the proxeses which determine the environmental fate of these compounds. Be. cause of their relatively high aqueous solubilitics and mersis. ence in soll. chlorinaled aliphalic hydrocartuons hnve heen defected in growndwater (15). In particular, vinyl chloride has received increased altention as a groundwater contami. nant, nince it is both toxic and carcinopenic to humnns (13). The presence of vinyl chloride in moundwaler has heen reported and was proposed to originate from degradntion of higher chlorinated aliphatic hydrocartons, such as inichlor roethylene and Ietrachlorocthylene (7-9). Addilionnl Intora. lory studics have, firmly estahlished that vinyl chloride can result from ceductive dechlorinntion of inichloracthylene. tetrachloristhylene, and dichloracthylene $(4,14)$.

Biotransfurmation of vinyl chloride under methanogenic conditions has been reported, nlthough degmdation w'ss shown to te relatively slow ond incomplete (1. 4). Less information is availatie on the nerobic biodegmuntion of vinyl chlurile. Hanman et al. (6) isolated a Myrohartertum strain which used vinyl chloride as the sole cartion and energy source for erowth. Roterts el al. (11) have ohserved degradation of vinyl chloride in an nquifer enriched with methane and oxysen. However, no deprndation occurred withoul methane enrichment.

The murmose of this study was to examine the nerohic deradation of vinyl chloride by noturally occuming micro. rwanism: in groundwater. Laboralory studies were con. ducted with woil-water micrncoum prepared from authentic aqulfer material.

Aquiler mnierial was ohained from a slie localed on the northern brink of llie South Canadian River from nn area hordering the municianl Iandfill in Noman, OkIn. (2). The water lable $n$ it the site has been roporied to he quite shnllow and rangen from approximately 0.610 : $1.5 \mathrm{~m}$ helow the wurface (12). The sample site did not receive lenchate from the adjacent landfill and was chowen to reprement an acrobic portion of the aquifet. Subaurfice noll amples were ob. iained from npproximatoly 0.5 to $1.0 \mathrm{~m}$ below the nurface and imnafeired to ototile glass jars. Oroundwater was col. lected by diagina a holo approximately $1102 \mathrm{~m}$ deep and allowine the hole to All. Oroundwater was then hatled into sterle one-gallon (3.7m4titer) daws botiles. The enmplen were chillert and sent to the laboratory in Midland. Mich.

Analyais of the suburiface soll for organic and inorganic contents and wil toxluro was porformed by A \& L. Midweat Iabomiones. Inc. (Omaha. Nebr.), by mtandard methods

\footnotetext{
- Corrvamindire outhor.
}

(3). The lotal number of hacterial cells nnd the number in viable micmonanisms nsoncinted with the subustivic ant

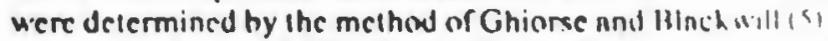

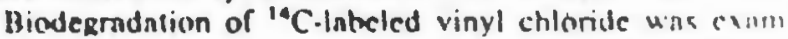
ined in microcosms prepnred with the subsurfnec sovil ans groundwaler. Snmples were prepared in $10 . \mathrm{mil}$ serum tulll, by combining $20 \mathrm{~g}$ (wel weighl) of solids with ?0 ml it groundwnter which had theen sterilized hy filtintion thrmush

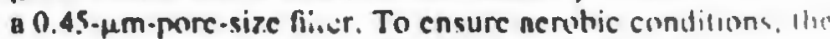

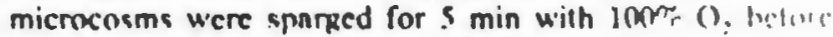
nditition of the intoled mnterint. The tholtles were then supplemented with nn nquecus solution of ${ }^{14} \mathrm{C}$-Inheled vinl chloride (specific activity, $0.53 \mathrm{mCi} / \mathrm{mmol}$ : Dumont. N! Resenreh Products, Boston. Mass.) to yicld a finnl concen Imtion of either 0.1 or $1.0 \mathrm{pmm}$ (KU/w't or grams of $1 \mathrm{mil}$ chloride per aram of acil 'nnd wanter) and senled with it Tefon-fnced hutyl rubber sepium and an nluminum crump seal. Reaction mixtures also contained rusazitrin (l).(M) as a redax indicntor. Autexinved controls were included to monitor abiotic degradntion. ns well as loss of test maierill from the microcosms. All snmpies were incubated $n$ ? the dark and apitated on a tissue cuiture minlur $1 . . . h$ continunlly rolled the hottles at $1 \mathrm{rmm}$.

Annlysis for "C.Intieled vinyl chloride in the nquems fraction was performed by high-performance liquid thrim:? logmphy. Before annlysis, the samples were chilled un $\mathrm{NC}$ for anproximntely $30 \mathrm{~min}$. Chromatogrnphy wns performed with a ZORRAX octyldecylsilnne column $14.6 \mathrm{~mm} \mathrm{hy} 29 \mathrm{~cm}$ Dumont) with acelonitrile.wnter $(50: 50)$ se the mohile phise delivered at $1.0 \mathrm{mVmin}$ by a Whtern 510 solvent delivers aytem. Radionctive compounds were detected by an on line mdionctivity monition unit (Benhold S(KA).

Total mdionctivity in the aqueous fanction was detemined by liquid scintillation counting. Triplicate snmples of the nquenus fmction $(20 \mathrm{O} \mu \mathrm{l})$ were counted in $10 \mathrm{ml}$ of liyull ocintillation counting cock/ail (Aqunsol: Dupont, NI:N).

Mineruliration of "C-Inbeled vinyl chloride to : (") ( ) in the renction mixtures wan determined during the allils. ${ }^{16} \mathrm{CO}$, war collected by pasing $\mathrm{N}_{2}$ ans $(250$ in $350 \mathrm{ml} / \mathrm{min})$ through the alurty mixtures, which had heen ncidifiel "ith $20 \mathrm{M} \mu \mathrm{l}$ of concentrated phosphoric acid. The purped gne wis collecled in a series of Iwo iraps, ench containing $10 \mathrm{ml}$ of 11 'I $N$ misasium hydroxide colution. One-milliliter mourms from the combined irmps were analyzed by liquid scinsulli tion counting. " $\mathrm{CO}_{2}$ production was confirmed by nddurg barium nitrate to the trap solution, mixing if for $30 \mathrm{~min}$, 11 ind determining the mdloactivity in the woivious afier removnl of the precipitale (10).

The phytical, chemical, and biological characteristics of the subwurface soil and eroundwater are summnrised in 
TABLE 1. Subsurface woil and proundwater chancteristica

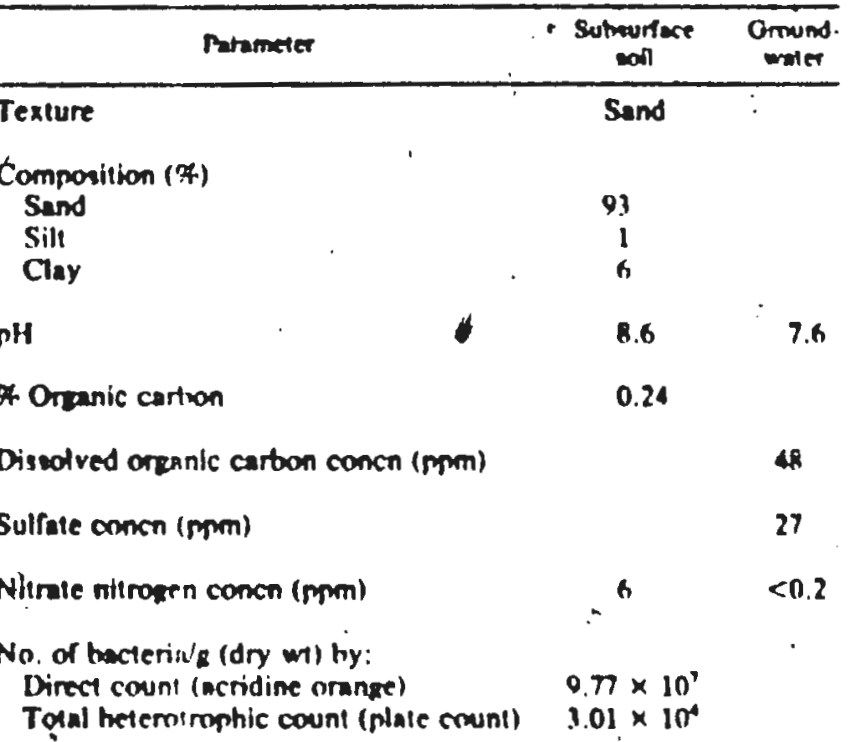

Tphle 1. The adids, which contained relatively little onanic carton, were classified as a and on the basis of low levels of aill and clay. The total number of mictooreanisms nseociated with the wolids. As def:'mined by acridine orange direct irunting. whe similiar to that observed by Beeman and Sulnita (2) in solids from anacrobic areas within the snme aquiler. The level of viable microorganisms associnted with the eolida determined by a minndand plate count (5) wns reveral onders of mapnitude lower than that determined by Jirect counting.

Blotraneformation of "C-labeled vinyl chloride $\mathrm{nl}$ lwo firferent concentrations was examined under acrobic condiions in the growndwaler microcosms. "C-lateled vinyl shloride $(1.0 \mathrm{mpm})$ was rendily depraded in the groundwaler umples (Fis. 1). No adnpuation or observable ing occurred xefore the Imnsformation of vinyl chloride, and approxi. nately $25 \%$ of the teal material was degraded during week I

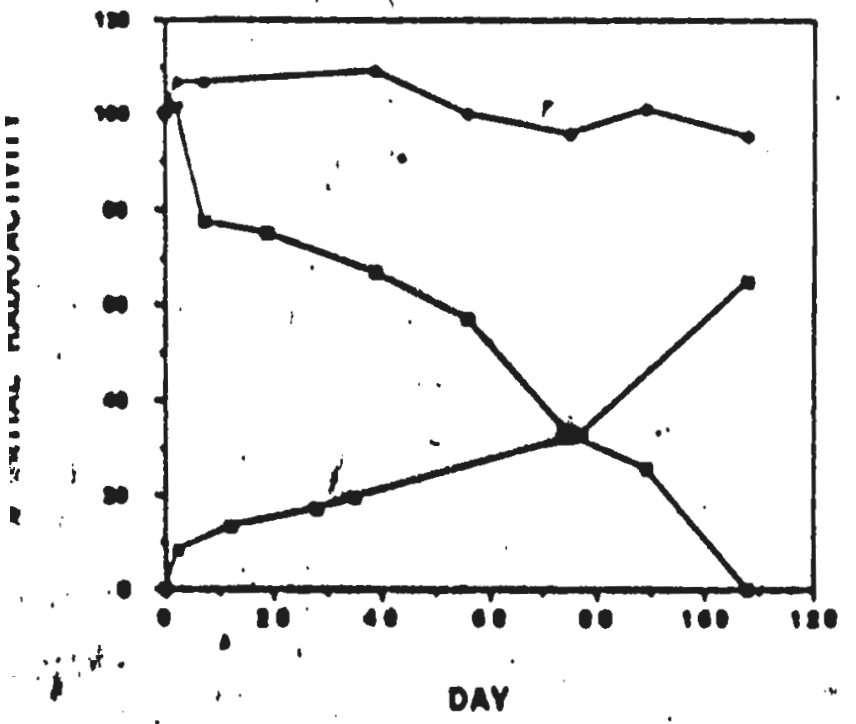

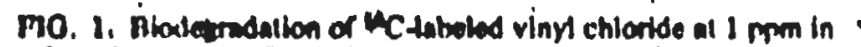

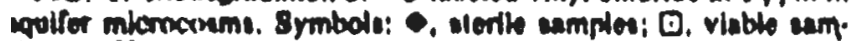

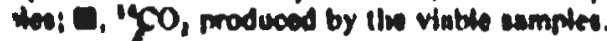

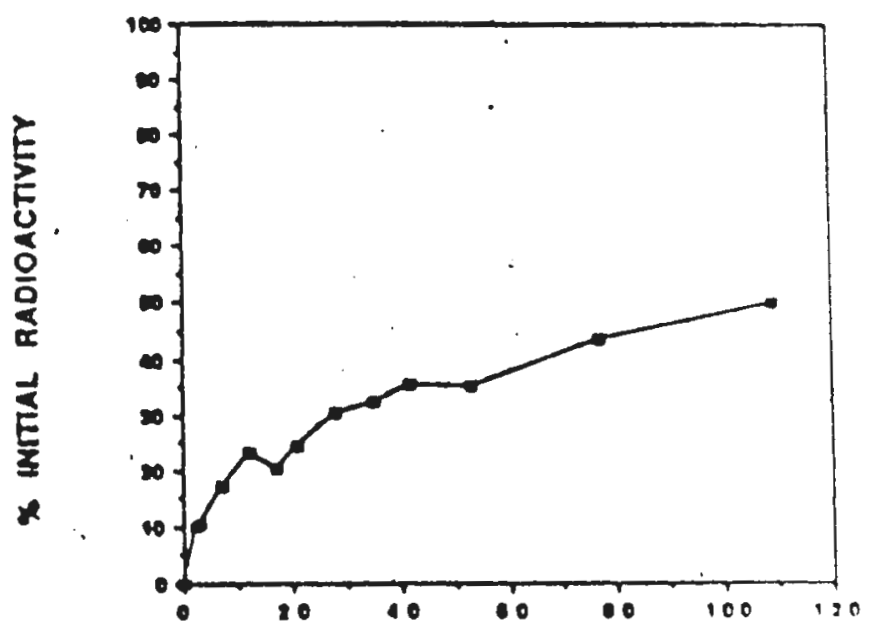

DAYS

FIO. 2. Diodegradalion of "C-labeled vinyl chloride nt 11 ipm

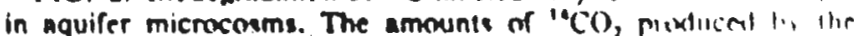
viable samples are shown. Less than $19{ }^{14} \mathrm{CO}$, was detested in lies stcrile contmls.

of incubation. Aner 108 days, grenter than gort. of th. wast material was degraded in the biologically nctive samiples. Vinyl chloride degradation was biologically medinied. unce Rrealer than 9.9\% of the labeled mnterinl was recovered from the aqueous frnclion in the sterile controls. Minerals:atturn necounted for much of the loss, since npproximntely , $^{\text {s.". of }}$ the inteled mnlerinl was recovered as " $\mathrm{CO}$, nffer lok, dis of incubntion.

To determine whether biodegradntion would excils ill lower concentmations of vinyl chloride. ndditional micrn. cosme were prenared an proviously described nnd pilked with the "C-labeled material at 0.1 nniti. Degradntiun if the test mnlerinl at this concentmtion whe monitored h. " $("(0)$, production only. The microorennisms present in the nejuifer materinl were copahle of minemlizing vinyl chlowide :I concentmations of 100 ppb nnd below (Fir. 2). Afier l(k) dars.

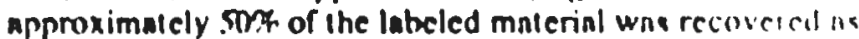
$11 \mathrm{CO}_{2}$. Mineralization wan not ohaerved in the sterile cinn. irols.

The results of this study demonstrate that vinyl chlisrite can be mpidly degmed under nerobic conditions the nbsence of an observable las or ndapiation period whs unexpected, since the aquifer $n$ this sile had no binkn previous exposure to vinyl chloride or other chinnnated solventin. Thus, the ability of microoreanisme nssocilited with woil and groundwater to degracle vinyl chloride mat the widespread. These resulta are consivient with those is other invertigalon (6) who have reported the occurrence of vinyl chloride-degrnding microorganisms associsicd with swil

This inventigation in the finst report of acrohic biontegra. dation of vimyl chloride in environmental anmples. Allhough there have been several reporti on vinyl chloride hiculegra. dalion (1. 11). previous thudles have relied on addilion of excenenovi nutrients, such at mothane, to demonatratc def. radation.

\section{WTHATURE CTTED}

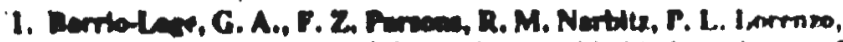
ead H. Fo Ardiv. 19x0. Bahanced anserobic biodegradnlion of vinyl chloride in mound waler. Bnviron. Toxicol. Chem. 0:4(1)413. 
3800

NOT:S

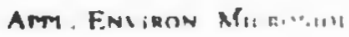

2. Eneman, R. I., and J. M. Selthts. 1967. Microtrial ecolong of a shellow unc unfined ground water nquifer nollued by municipal landAll leachate. Microh. Bcol. 14:?Q-54.

3. Mech, C. A., D. D. Evere, J. L. White, L. E. Fenominatr, and F. E. C7ert. 1965. Methods of coll enalysis. American Society for Apronony, Madison, Wis.

4. Frendmen, I. 1., and J. M. Comett. 19R9. Binlopical reduclive dechlorination of ieinchlonothylene and trichlorethylene w ethylene uniter methanogenic conditions. Ampl. Environ. Mi. crobiol. 55:? 144-2151.

5. Chiore, H. C., and D. L. Ruckwth. 1983, Enumerntion and momphogic al characterisation of hacteris indigenous io suh. wurfece environmente. Dev. Iod. Micmhiol. 24:213-224.

6. Hertme S., J. A. M. de Mon, J. Trumper, and K. C. A. M.

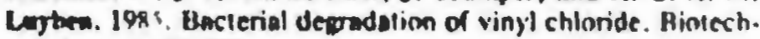
not. Let1, 7: 18!-3RR.

7. Mode, 6., M. Nenter, and R. Merider. 1969 . Biolupical depm. dation of vilatile chlorinated hydrocathoms in mund water. Water Sci. Tech. 20:57-7.1.

f. Mation, P. M., R. T. Herien, and 3. H. Dre. 1W7. Study of vingl chlovide formation nt lendfill siter in Califomin. HNW'. 231120607 Intlelle Pacific Northweel Lahoratories, Richland. Wash.

9. Mrem, R. H., H. L. Credt, and R. Minalyy, 19R7. The ute of microtrial in sifu Ireatment for detoxificatom of a contaminated ground watct. In lthecedings of the NH'A'A Focis Cionferen: on Midwestem Ground Water Isstes. National Winier Wril Accociatum. Inthlin. Ohio.

10. Raphin, F. 19k2. Mensurement of " ${ }^{4} \mathrm{CO}$, scintillnfion tech niques. Pocknrd technical hulletin no. 7. Packnnd Inwminem? Co.. La Grange. III.

11. Roherta, P. V.. I. Semprinl, G. D. IInphins, D. Cothlefialis. P. L. MrCert, and M. Metnhard. 1089. In.rilu nuwifer rews: tion of chlorinated aliphatics hy methanotrophic bactena li'

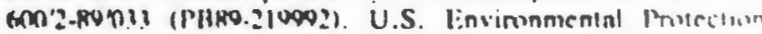
Apency. Whahington, D.C.

12. Rohertion. J.. C. R. Tousealnt, and M. Jorque. 1974. ()rgin!,

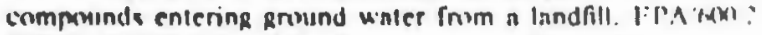
$74 n 77$ (VH2!7. W.9). U.S. Envirunmental Itroction Apent Wnshington, D.C.

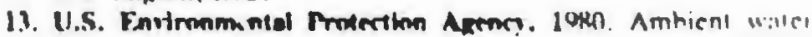

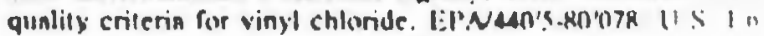
virunmental Irvetection Agency. Washington, I).C.

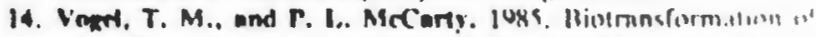
icinchloricthylene to irichloricthytene. Jichlorictlutene.

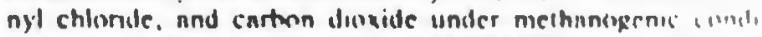

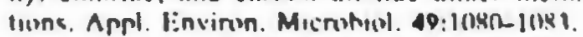

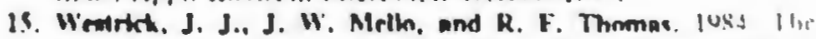
griwnd water supply survey. J. Am. Hiter Winks Assm $76: 52-50$. 


\section{ver California Seismic Hot Spot}

hibel. dexors w whe open and romce wroke with s start last ! mollis homk south of S.an "w win luse irthejuske we've 1 H. 14 if the l.ake E.lsman inmolunges stich as I.indh. $\therefore$ : crrhor reke and its ncis

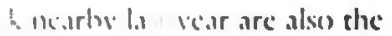

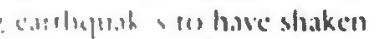

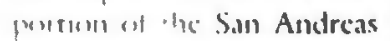

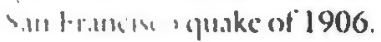
ithen th.t w'pluncent of the San mere stumsle thin weher n, I mil' n/m lives , h.alf " tusle. (oll kilenemeters south (1) 114,20 kilometers to the 1 lom "

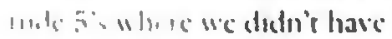
"utuly 4 " .mollume h.yplened; I can "d " that fecling now."

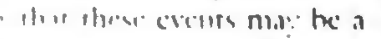

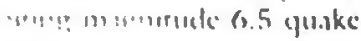

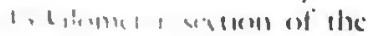
1.e1, . I I the I.lom.un. This - Anm thendenth the southern

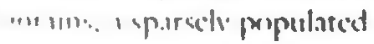
181 , 1., th wheh of Silicon

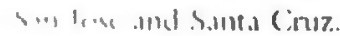

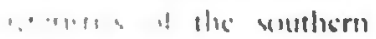
. as? ( 1,forme sckemtic dinger.

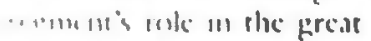
11.1. juske I1 was here that

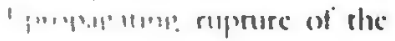
a the men, ' of slippoge be1. . ent 's' l.mile during the

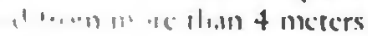

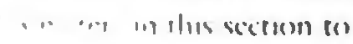

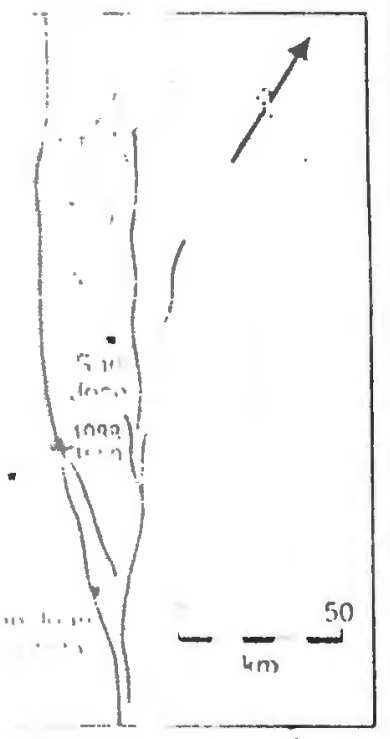

zero at its southern end, near San Juan Bautista. But every part of the fault must slip several meters even few hundred years on average: the driting of the continents requires it. So, scismologists expect one or more moxderate carthquakes on such terminal segnients to make up for the shortiall in faule slip in 1906

Another worrisome circunstance is the length of tault that would break in any quakes that help the slippage catch up. If the southern end of the 1906 breis were sutulivieled into a series of segments, each only a fiw kilometers long, the quakes would ixe small and relativels harniless. But in 1983 l.indh, who works at the U.S. Goological Sunce office in Menlo Park, elecided that the entire 45 kiloneters of fault south of l.ake Elsman w'as a single segment that would break all at once. If $\mathrm{so}$, a respectable corthquake of magnitnde 6.5 would result.
In the bargest experinent of its kind, Exxon Corporation is tring to fied notive Alaskan bacteria. The hungry microtes slurp cil and, if Exxon can grow lots of then, they'll help skan up beaches that were stained with the snucle oil dumped by the companv's tanker, the loulde: last April. -

By: Scptemler, says Bob Mastracchice who heads Exx(m)'s clcaump program, the company intends (o) coat 70 miles of shoreline with mo kinds of nitrogen- and phos. phorous-twaring fertilizers to toost the indigcmous hacterial populations. Exxon is so comfictent about the perential of the ap. proach that it is gombling $\$ 10$ million on the effort.

But Exxon's contidence rests on a limited experimental hasc. The company, in conjunction with the Environmentenl Protection Agency (FPA), hegan experiments huith the firtilizers in carly Junce on fius rest plots mensuring 30 necters by 12 meters. Twe noure plors were used as controls and were note trented. "Within 10 days a clear rectan. gle apperared ag.inst a backgeround of oilcilltanninated hexch matcrial," says $H$ ap $H$. Pritcluard, a microbial cololngist in EPA's Office of Research and Development.

But Iritchard, who nomally is stationed . I I:PA's Ciulf Brecze. Florida, research latoraron', sase it is hard to quantifi just how stictive the fertilizer realls is. Ficen withent (hemical treatment. "rhere is significant bio). degradarion going on," he says. Anorher vortalile, he adds, is the uncertainn aturut

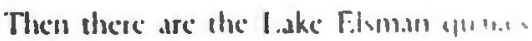
They are nwe of the threc largest sarthquakes since 1914 on the 420 kiluneters ost the northern San.Andicas. Eacti brokc. nivuut a l-kilometer patch of fiult at clepitis of 14 kiloncters within a kiloneter or two of the incersection of the San Andreas and a wh fault called the Sargent, right at $1.3 \mathrm{ke}$ I le

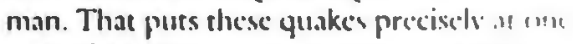
end of Lindh's scgnent. Oticn a liull s"

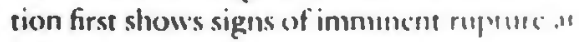
its ends.

With more and more signs that ihe wisth crn Santa Cruz Mountains segrment is dan gerous, scismologists arc starting (1) genc ir the ancorion an inunceliate threat descon A USGS working group estiminted lass war. Ixfore the first Lake I:Isnian comlinissoke that the southern Santa Crue secturom lias atout a $30 \%$ probshilin of hre.skun! w w? rime during the next 30 years (S.6m, ? lul. 1988. p. 413). No onc a tormalls raising that probability, but I.mdh's scusา logical intuition tells him they hetter assumb the worst.

- Richard A. Kap.

\section{Exxon Bets on Bugs in Alaska Cleanup}

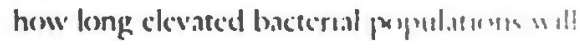
the sustained with just onc applicitem $A$

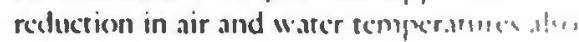
is expected (1) reduce bacnerial acroirs

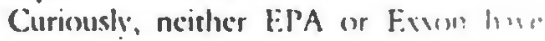
donc much work to identifi the dill, : :

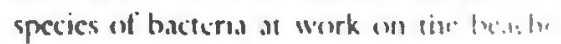

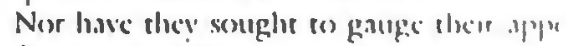
rite for oil. With a narrow uns trans lin exceuting the plan before winter sienes in. Mastracchio says there has not hecen func fi" such basic rescarch.

One of the chenicals en he used n" "/minul EAP 22," a specsal fertilizer created for ithe

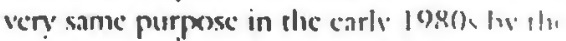

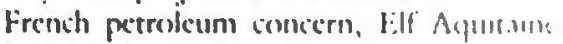
But the chemical's only major deplowment cxcurred in 1985 In help mup up il t. smaller spill of refined marinc oul.

The use of the fertilizers, l:IPA m/ / wm

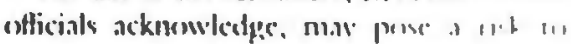

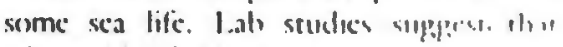
where tidal flushing is minimal, nutrog:cos leaching fertilizers could be tovic we elw lan'ac of sea urchins, oxsters, and musseck For this reason, FIP is monitoring shilltivil, but $s)$ far there is no cridence that ther an bxing afficted.

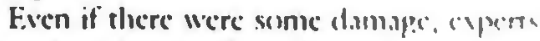
vicw the risk as small relative to the porecuse d!

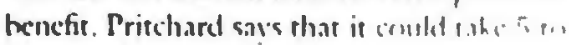
7 years for oil on beaches 11 bre it dimen under narural comditions. With the lertilizal rion proggran that time could he redificed me 2 to 5 vears.

- Mark Crawionan 


\section{Bacteria Effective in Alaska Cleanup}

A year after the Exxon Valdex dumpral its urgointo Hince William Sound, oitsoatrad Ixaches that were tratod with an experimental deanup technique are begining to retum to normal. Indeod, the cechnique has numad out to be so cliective that even some of the scientists who helped develop it are copreasing surprive.

Last summer, in a $\$ 10$-million aperiment, Exoon reseanchers aprayod same 70 miles of beaches around Prince William Sound with a fertiliser callod Inipol that was developed in the earty 1980s by the Freach petroleum company Elf Aquieme. The goal: to stimulate the growth of naturally occurring becreria known wo have an apperite for hydrocartoons. It was the biggest test ever conducted of the use al bectecria m dean up an oil spill (Srima, 18 Augurs 1989, p. 704).

Though nobody is touting the rechnique as a cure for every oil-foulad beach, preliminary surveys conducted last surnmer by the Environmental Procoction Agency (EPA), which is participating in the test, indicated that the aprayod beaches showed dramatic improwement compared to untreated areas-uaually within $15 \mathrm{dam}$ Now laboratory tests performed this winter have provided decailod eupport tor these observations.

For cxample, scientists found two onders of magnitude greater microbial cenents on beaches soon after they were treared than existed in untreared areat. And the effact lasted, with elevated levets of oil-degrading bacueria persisting 5 monchs after spraying, according to Rusuell R. Chianelli, senior roseanch asociate Exon Rescarch and Engincering Company. Bex of all, the becteria numed out to have a much greater apperite for oil than anyone had imagined, ays Chianelli. In Ect, EPA's and Exaron's daw collection efforts were initially hampered because the organisms even artacked some compounds in the crude oil that reseanchers were hoping to use as long-term marters for atarisical analyses.

Still, to be determined is how effective the rochnique is in digeating oil that has penetrated porous arore or migrated below the surface of pebble beaches. EPA and Exon researchers say the fercilizer scems to be stimulating increased degradacion to depths of about 1 foot, but biological activity there may occur at a slower rate. Chianclli reports, however, that preliminary tess indicare that oil bencen aurface rocks was consumed by microorganisms in about 40 to 50 days.

As for roxic effects, so far no significant impact has been seen in mued barve and oyster larvac, says Hap H. Pritchard, a microbial coologier with EPA. Nor did the chemicals simply dissolve oil on the beaches and cause it wo run of into the wound, as some rescarchers had feared, wys Pritchand.

Nl this mates one of the originators of the rechniqui-Ronald $M$. Adas, a professor of biology at the University of Louisville, who firs experimented with fertilaer formulations similar to Inipol in the late 1960 -ecratic. Currendy worting 2s a consulant for Exxon on the cleanup, Adse sys "There were more dramatic surface resules than anyone had prodicted."

But while these results are encouraging. EPA officials are quict to poirt our that the method is not a magic, cheap solution nor a cure-ill for oil spills. Every beach tha was ureated first had to be howed down to dispene the oil scroen the aurface of the beach before the fertilizer was applied. The technique abo is nox litety to be unefis on rocty portions of the 1089 miles of Alate shoreline conteminaced by oil besuse the fertilizer soluvion will not ding to vertical surfsces. This could also limit the thefulnes: of the rechnique on sxeeply sloping beachea, EPA oficials say. Furthermontyte level of biological activity declines with cold weather-by some $75 \%$ just 8 solotist expected. Quantifying the effects of biological degradation particularty inthistes is difficut because of increased physical washing that resulo from wave actic

Neverthelese, the creatment surategy has worted well enough for Eroon fin sinue to experiment. This summer the compeny is expected to cupend the use of thitions into additional parts of Prince Willian Sound. It ato has epurred the American Petrokum Instiute to sep up rocarch on becterial scouring. Monecrex, Ads predicts that the resules will trigger a wave of new rescarch by oil complice, EPA, and universitics to better understand how shoreline microorganism brets down oil. It could also stimulate intercer in developing more advanced bionemediacios anechods

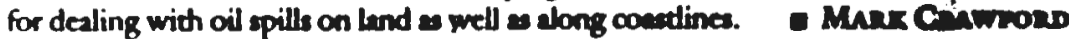




\section{"Valdez 'Bugs' Chomp Away." Science News, 136, 15 July 1989, 38. \\ Austratia during the cold period and muved south over thousands of years as the climate warmed. Alternatively, they mal have remained in the south through the frigid times. \\ Deadly RSV may fali to improved vaccines}

Researchers cannot yet determine whether dinosaurs survived cold winters in Australia, Rich says. The newest isoupe samples come from rock layers nearer the bone beds, so they should give a better picture of the dinosaurs' habitat than did previous isotope data. However. even the closest samples are not contemporaneous with the bone beds. "They are separated by 2 to 3 meters vertically," he says. "That could still be a couple of millennia" . $\quad-R$. Monaslersky

\section{Valdez 'bugs' chomp away}

- Last month. Environmental Protection Agency biologists initiated experiments in a soiled beach in Alaska's Prince William Sound to see whether treating its sandy and rocky shoreline with either of iwo types of lertilizer would enhance the natural detoxilication of crude-oil resi. dues (SN: 6/17/89, p.383). Preliminary data from those tests, released late last week. indicate that fertilizing indigenous aquatic bacteria indeed appears to accelcrille the breakdnwn of oil spilled Irom the Excon Voldez supertanker.

" According to the EPA report. "nafural bicdegradation of the oil was already welk under way ... by the time the fertilizer was applied." This, it says, explains why the researchers lound so many oil-degrading inicrobes at the start of their study. Jusi cn' week alter beach fertilization began. however, the microbiat communities had expanded measurably. And, as sus. pected, the lertilizers' lormulations appeared to influence their efficacy. Sites preated with the waler-soluble lertilizer - Contained 30 times more oil-degrading bacteria than did untreated beach plots. Sites sprayed with a lertilizer incorporat. iny, a vegetable oil to help it bind to the rude nil. however, housed 100 times mirr of the beneficial bacteria than nearhy unireilrod rones.

Observation of the oll/fertilizer-treatment areas "clearly shows a striking disappearance of the [tanker] oil from roik surlaces," the report says. While EPA scientists haven't established that the bacteria ate the oil rather than simply Imusening it to he washed back into the sulund, such analyses are underway. Farly (lala $d($ ) indicate that the fertilizers have nol collecled in near-shore waters or overfed olfshore algae, contributing to an cxygen-depleting algal bloom.

Noting the preliminary success of these bacterial-feeding regimes, EPA has expanded its Valder microbial-detoxifica(ii)n program in include studies of nutrient movement within the beach and to monitor inr adverse ellects of the nutrient releases.
In the alphabet soup of childhood vaccines, pediatricians hope the letlers RSV will someday become as lamiliar as DPT. Diphtheria, pertussis and telisnus once major causes of illness and death among children - have all but disap. peared in the United States since devel. opment of the DPT vaccine. Not so with RSV.

RSV stands for respiratory syncylial virus, an influenza-like virus and the single most importánt cause of lower respiralory iract infection in infants and children. In the United States. RSV kills about 2,000 infants each year and hospitalizes an additional 55,000. Despite dec. ades of attempts, major problems have stymied scientists' elforts to develop a vaccine against RSV, which spreads through close contact with infected chil. dren and adults and blooms in epidemic prope. " ions each winter.

At this week's annual meeting of the American Society of Virology in London. Ontario, scientists provided some encouraging reports of RSV vaccine prog. ress. Researchers estimate a commercially available vaccine remains three (6) five years away. But ongoing trials in animals and small numbers of humans now suggest they have overcome the major obstacles of previous years. An experimental vaccine in the 1960s en hanced the disease in some children. leading to some deaths and a strategy change among RSV varcine researchers. Rather than working with inactivated whole viruses, scientists today use pu. rilied, antibody-provoking RSV proteins.

After years of tests in rodents and primates, scientísts Irom Praxis Biologics in Rochester, N.Y., say they have immunized 40 adults and 23 loddlers 2 to 1 years old with a purifled protein from the RSV outer jacket. They find high levels of protective antibodies. no discase $\mathrm{cn}$ hancement and no notatsle adverse renc tions, says Praxis researcher Thoun:s Kostyk. Pending Food and Drug Adminis. tration review of the data. Praxis hopes (o) begin tests in younger children.

Michael $W$. Wathen and his colleagues at the Upiohn Co. in Kalamazoo, Mich., report thrir rrration of a genetically engineered vactim made' $1 \mathrm{rnm}$ a com. bination ol two RSV proll-ib. rinv sily lests in rats suggest their "chiturits fo. tein" triggers a stronger imnune «" sponse than does the single protein Praxis uses. Inoculation with the engineered protein protected rats from infer. tion when they were challenged with a nasal spray of RSV. The company plans in expand to primate irials and expecis in vaccinate humans within two years, says Upiohn virologin Roger J. Brideau.

$-R$. Weiss 


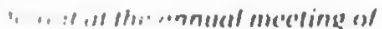

\section{i.hrtic eve-disease risk}

wilur later in increased risk of 1m: ".e" tiscase called retinopaIth. linding highlights thw need l:uin ind prount treatment of

". 11 the liniversity of Wiscon-

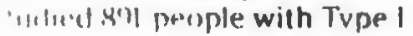
in ingerisuns in help them tourtiers foushd that syestolic bir.. "ustre shtained when the prodictor" of whether these "III indumpustliy

she houd pressure rendings I morcury - at the start of the

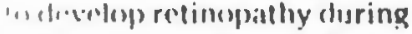
11$, ivstulic readings of $11 \mathrm{l}) \mathrm{mm}$

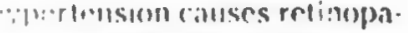
"1 very high blood prossure "Hweye Relinopathy accurs "y?" the redina, causing blurry lliv in most diabetics. But in ش॥ukls up scar tissue, causing

... lvpr-lorinsulin-dependent ther thisease.

\section{Inping children}

"ll dimbes has mul been'asso1) fumclioning in childhood. But reovever Canoudian study hint 'i lu"l.e may have deficits in

in! an the Huspital for Sick risul a three-year prospertive arrilled within I wo nonths of fo.". sthlings At the startot the - Herer hervasue the children a -1 ine:ivilure spatial and verbal

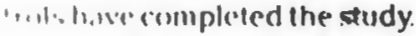

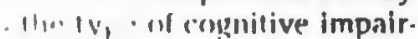
". th the time al diagnosis. For tow. llewir lifth birthday. the

- lor.ull responsible for spatial $1 \%$, finmel that compared with

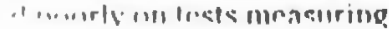

\section{Science \& Society -}

\section{Microbes recruited in Valdez cleanup}

Just alter midnight on March 24, the Exxon Valdez superlanker ran aground in Alaska's Prince William Sound, spilling 10.1 million gallons of crude oil and fouling 368 miles of shoreline in.that sound alone. Roughly 2.500 people have already enlisted in the manual cleanup of area beaches and wildtile. But the newest recruits in the cleanup are local communities of bacteria that specialize in detoxification.

Last week. Environmental Protection Agency scientists began seeding six oil-stained beach plots with nitrogen and phosphorus fertilizer in a 2-acre experiment at Alaska's Snug Harbor. Previous studies had delected air-breathing bacteria in Prince William Sound and nearby beach waters with the ability in break down slowly volatilizing alkanes (straight-chained compounds) and simple aromatic (ring-shaped) hydrocarbons. Together. these compounds represent about halt the oil left on the beaches. Moreover, says EPA's Map Pritchard in Valdez. Alaska, they account for most of that oil's toxicity.

The 90-day test will compare two nutrient formulations aimed at spurring the yet-unidentified bacteria's growth and alkane/aromatic degradation. One formulation incorporates oleic acid, best known as the primary falty acid in olive oil. Researchers conducting the test think this "fat" will glue the Inixed-in bacterial nutrients to any crude oil on which they're sprayed. The other formulation is an. olf-the-shelf fertilizer "brickette." The researchers are packing several brickeltes into biodegradable plastic sacks and tying the sacks to pipes anchored in the beach. Over the course of a month, they expect wave and tidal action to llush the slowly dissolving lertilizer back and forth across the shoreline's rocks and sand.

The team will use its preliminary data, available by early July. to determine whether either formulation oflers enough promise Ior widespread treatment of Alaska's beaches. Neither regimen, however, can restore allected beaches to their former, nearly pristine slate. Because these bacteria ignore asphalllike oil constituents, a tarry residue will remain.

\section{NAS suspends collaboration with China}

The U.S. National Academy of Sciences (NAS) is "shocked and dismayed by the artion of Chinese government troops against peacelul demonstrators in Tiananmen Square and elsewhere in Beijing. with such great loss ol lile," NAS President Frank Press said in a telex to Chinese oflicials last week. "While we earnestly hope to maintain our cooperation with ... Chinese institutions," he added, "we must suspend all aclivities for the time being. We do so in outrage and sadness."

Acrording to Róbert B. Geyer, who heads NAS' China ollice in Washington. DC., those most strongly allected by the NAS 
THE TINIEST
TOXIC AVENGERS

More c eanup companies are using bacteria that gobble up wastes

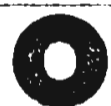

the 1,100 miles of Alaskan storeline fouled last year by the f. con Valdez, few plices suffered mo! " than Passage Cove on Prince William : ound's Knight Island. Within lays, $(3)$ reped nearly two feet into its Lrivel-ind sand beaches. Even hot-water sprain is In't help much. By mid-July, saw li. "re 1. Mastracchio, Exxon fori $\because 1$, hnical manager in Alaska, the thorr wis still "black and gooey."

That s shrol scientists decided to inclle (11. natives-microorganisms that live in 5, and water. They sprayed the beach w' fortilizer, hoping that adding nutronto would stimulate the naturally cervirrins lacteria to feed on the gunk. Thre' w..k's later, the fertilized areas urre new ly clean of oil for a foot down, while u rated areas wore a sticky cinat Ant researchers found that the propulatiin of voracious bugs in the ferLilized sd, had increased a hundredfold. This wonks. The Valdez, cleanup, while Phar from complete, is the otggest success vol ar a technique called bioreme Tiation "uch uses natures tiniest crealures in clean up mankind's btegest messes "Weve proven that this works," says stip tist John A. Glaser of the Envirumeni al Prolection Agrency. On May
2 Alaskan officials gave Exxon approval to fertilize 35 more miles of spoiled shoreline this summer.

Now, more than three dozen cleanup compunies are turning to organisms that scarf up everything from diesel oil to highty toxic polychlorinated biphenyls (PCBS) and heavy melals, which were once thought to be impervious to decontamination. But it turns out that "there are bacteria that will eat anything." says Richard C. Cassin, founder of San Diego startup Bioremediation. Inc.

This year, the market for bioremediation products and services is only about $\$ 30$ million, says Concord (N. H.) environmental consultant William T. Lorenz. But $t$ may be ready to bust loose. Some companies are netting contracts of more than $\$ 1$ million, far higher than the $\$ 250,000$ or so that was cominon just two years ago. Venture capitalists are beginning to fund a few startups, and even traditional waste-treaters such as it Corp. are using more bioremediation.

The trend comes just in time. The EPA estimates that conventional cleanups of some 1,200 U.S. Superfund sites, areas of extreme contamination, would cost $\$ 24$ billion. Some methods, such as incinerating contaminated soil, can run up to
$\$ 1,000$ per ton-and are under allack from both regulators and the public as potentially unsafe. Bioremediation, by contrast, typically costs less than $\$(x) i$ it ton. It also offers a big advantage lo stead of simply relocating the priblem. bacteria eliminate it. And bioremediation may be safer; It has been used in wa't $l^{2}$ water-treatmeat plants-ind evin out. houses-for half a century.

ear amo or. To obtain the right clem nup bugs, scientists typically take soil or $\cdots$ it ter samples from a loxir sitn- $\{\ldots$. has even scraped oil deposits we wis driveway-and grow the micrminast. isms they contsin in a lab Somm of ...... bacteria feed on the cartion aluth : "rial make up organic chemicals. $15, \|_{\mathrm{y}} \mathrm{i}$ breaking the chemicals down to $\because$ dioxide and water. Researchers car tion breed strains that depend on a conta: ri: nant to live and that will die off (1m:? the. food soures is gone. That way, bl..... little riak that they'll run numb

The quickest way to trat comlamminat ed soil is to excavate it, mix it un with water, nutrients, and bacteria on a mastic sheet, and pump air througl: 1. . In early 1989, Groundwater Technology Inc. in Norwood, Mass., used this method to clean up an oily mess at a Truas oil-storage facility in eigbt werlis. (A) taminater groundwrter is usuall: treat. ed in a "bioreactor"- a tank contanung specially selected bugs. Randall ; von Wedel, president of Cytceulture Internattional Inc. in Point Richmond, (alle hopes his company can shave monthe off a two-year project by pumping hacterial. laden water back into ground that has been contaminated with dissel fuel.

For all the recent success, bioremedia tion faces huge obstacles beforr it bo.
BIOREMEDIATION: A BARGAIN FOR CLEANIIU UP SOIL $\$ 50 \nmid \$ 100$ 。ion monemedation

$\$ 50-\$ 100$ oion

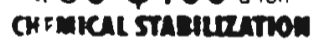

$\$ 200$ oton Tyterinat exsonimom

$\$ 300-\$ 400$ aton

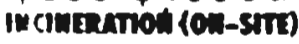

$\$ 1,000$ aton in:mbémon (OFf-sm)

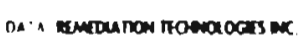
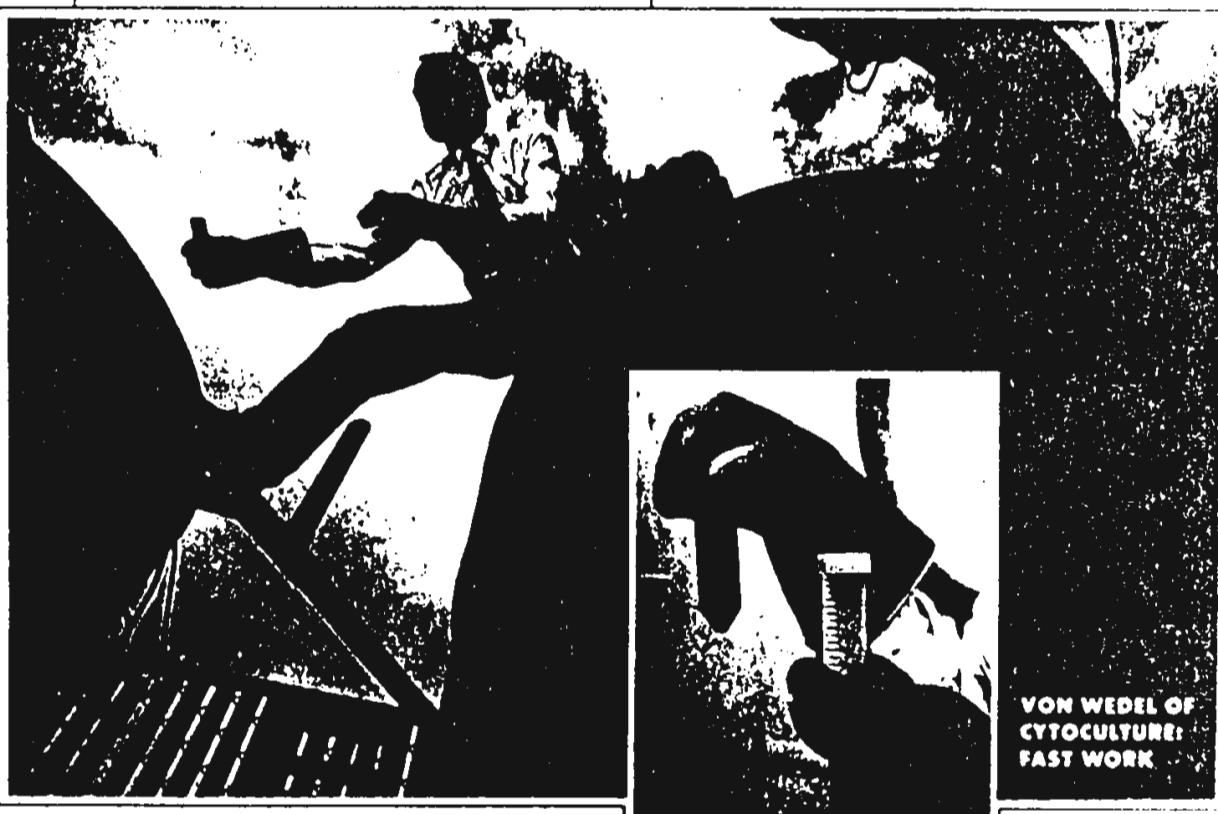
comes the preferred pollution treatment. It usually tikes longer for bacurria to work than for soil to be hauled away or incinerated, and bugs often stop munching before the contaminant is gone. One problem: They need nutrients and oxygren. "You can't just take a bag of bacte:ria and throw it on the ground," says Roger J. Colley, president of Envirogen Inc., a Lawrenceville (N. J.) startup.

Now, scientists, are finding anaerobic bacteria, which can survive without oxygren. For instunce, Woods Hole Oceanographic Institution in Massachusetts has discovered anatembic bacteria living nur warm water vents $6,6 \times$ feet deep in the Gulf of California that can degrade raphthalene, a stubtorn hydrociarton. And Cieneral Eilectror Co has found woth anaerobic and oxygen-dependent bugs that could help clean up 500,000 pounds of 'p'Bs in a f(0)-mile stretch of the Hudson River irpusstate New York.

MELPful ruwous Another limitition for today's tiny woxic avengers: Bugss usual. ly attack only ohe contaminant. So they may be useless in some of the worst waste sites, which contain many different toxins. One idea is $w$ use grenetically engineared organisnis for these. Enviro ren is exploring the insertion of several remediation genes inw Escherichia coli bacteria, perhaps the most common around. But regulators must mprenves the use of any genetically engrineererd organisms. The Electric Power Research Institute, looking $a$ clean up power. plant waste, hopes to avoid that by ad. justing environmental factors, such as nutrients and oxygren, to get orgamisms to exchange genetic material naturally.

The search is also on for bioremedias. cion bugs w lackle even tougher problems. Bacteria found at the Finergy Dept.'s Hanford Reservation nuclear la. cility in Washington State keep radioas. tive materials such as cesium and urim. In attached to rocks and soil-and unt of groundwater. And researchers at the University of California at Riversides have found a fungus that dotoxifres sillenium, a metal that causes birth dofrets in migrating birds in Califormia's Contril Valley. Last month, a University of $11 \mathrm{ll}$ nois professor even described a hacteriaproduced detergent that could he sprayed on keaches before a sibill ar. rives, w prevent oil from sticking.

Some environmentalists still have reservations: In Alaska, they fear that fortilizers used to stimulate bugs may harm wildlife. They also worry that business may simply see bioremediation as a way to avoid more thorough cleanups. But sie scientist Daniel A. Ahramowicz disagrees: His studies show that natural bacteria are already slowly enting some $\therefore$ MrAs in the Hudson river. The challenge now is to help them along.

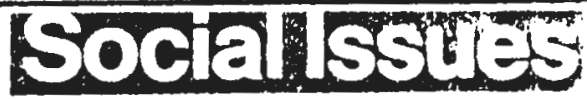

\section{roucation}
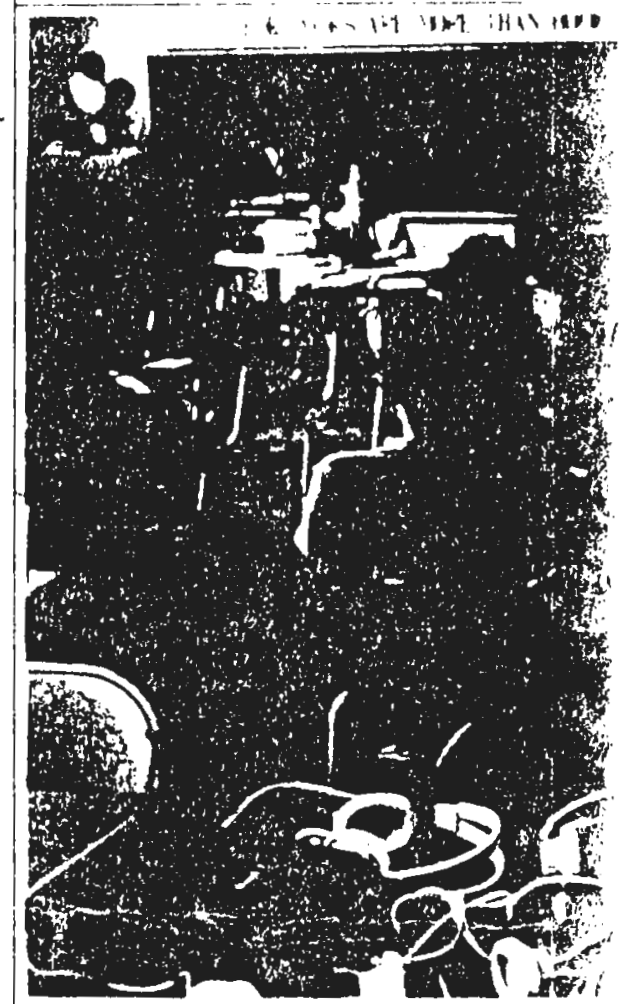

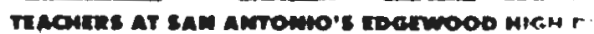

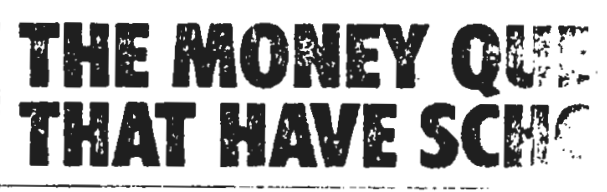

Is equal spending one curc for 11 :

6 nything Pou can imarim.

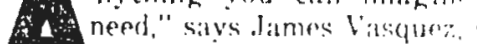
perintendent of the Fidrewa. independent $\operatorname{sch}(x) \mid$ detriet in Siln Aul. nio. In this fow-income, hargenly Hispic. districe, ecachers often dig inten thrir ou. pockets to pay for hasie supplies Mar: classromes are not astonditioned. and temperatures can soar above lokf in $1:$. Texas heat. High school students shan a few lo-yorald computers.

Vasquerz says such condilith refo. the leset he can der on an :mmukl hudi...

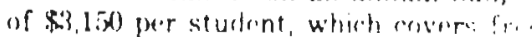

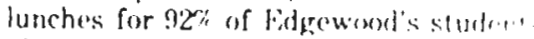
flus vachers, books, and minintriame. In contrast, upper-middle-elass ( $\mid+\cdots, 1$. lake High near Houston has (wo libra.

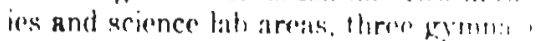

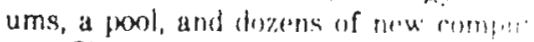
ers. Clear Inkr's distrul tak bake a,

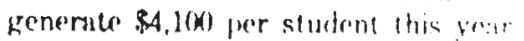
and locals recently passord a $\$ 22$ milim. tond issue to build new school farilit... 


\section{Toxic wastes? A little fungus may helig}

11149ullut! on the callant

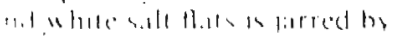

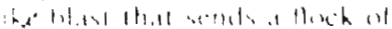

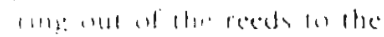

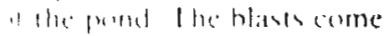

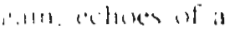
lit salse waller

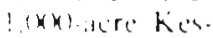
, $11: H_{1} H_{1}, \cdot R, 1$

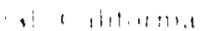

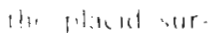

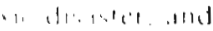

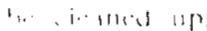

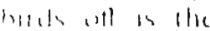

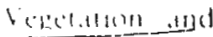
minminaled with ! 1 1 the state now whumm Bull.

(19) 6) anters of

+ 1."mp 11 mon a plas

$\because$ are lamblfll

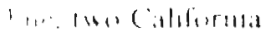

periche agatumst

: lif proce thara tiny .in dis a belter job

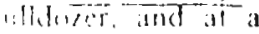

1 he There

vituritts acurreng

1:1' att comorere sele

matrobereg

uscentul. therr project uh the commeng of age of a new molnsual cleanup Nationwide.

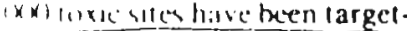
lainu by the Tonvonmental

Ageney thi expensive.

inpriach ordered al Kester.

wh 15 picin of the rectinolugy

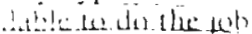

tem s shortiall

an viouthles are the reciult of

- hemolut that him leen unnatu-

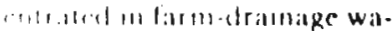

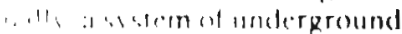

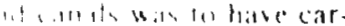

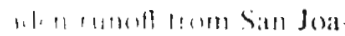

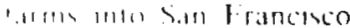
- .... 1' lind mal the camal k, $\cdots / 2$ resm is

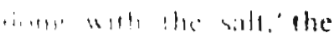

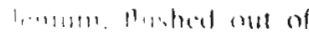
whe mal antink sobked

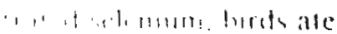

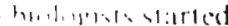

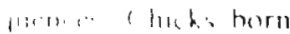

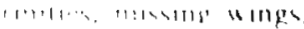

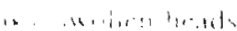

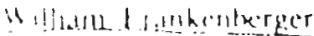

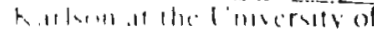

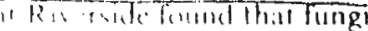
and

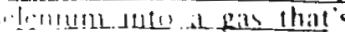

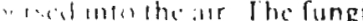

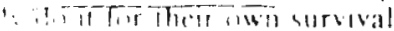

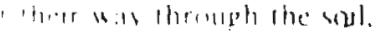

SCIENCE - Biologisis are Irying lo prove that, in the cleanup of polluled soul, invisible microbes are better than bulldozers

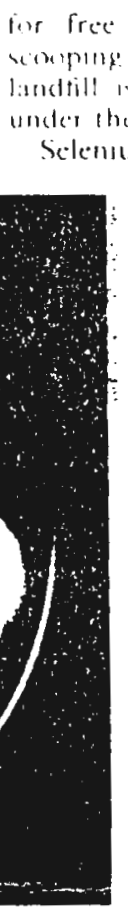

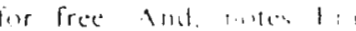

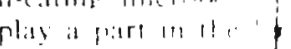

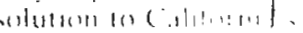
dramatge proher... (ant mall... pian. $1 !$ ?

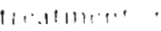
Srithen

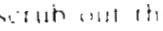
then whald it dumped int. ponds [he and should the tathe wh A yen for pollubin:

A cimmin...

fungus mat in

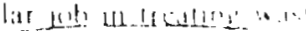

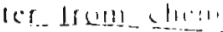
The cormen it. Thans 10) ches throush lan! on:

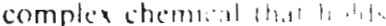

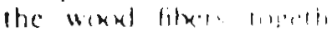
(a) alus degent wing he

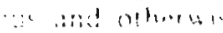
w4ath ;ollotin: comolofoges!

they in effect spit out the selenium that would otherwise build up to a lethal dose. What Frankenberger and Kaclson ace trying to do is speed up the process. They studied habits of fungi with an eye to learning how to create a hospitable environment for them. "We're Farmung" for fungl-adding manure, rolotilling or Jiscing to derate the soil, adding walcr." explans Frankenterger

Biological cleanup ofters some big advantages. Mamly. it's cheap. The balle's hulldozing plan is estimated 16 corst at least $\$ 25$ million; the fungi work

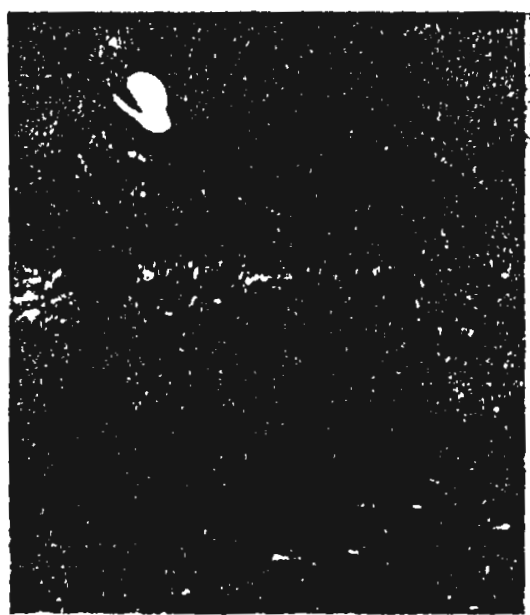

Farming for fungi al a toxic-waste site

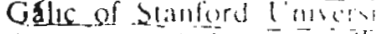

demonstrated that naturalli mou

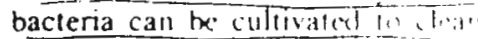

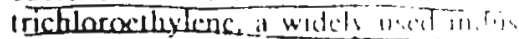
irial solvent that has imtumit.

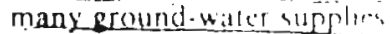

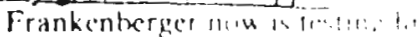

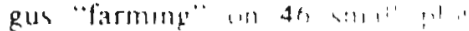

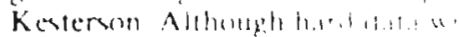

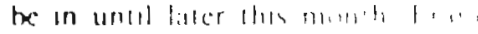

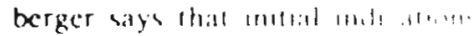

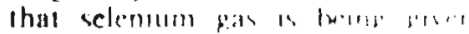

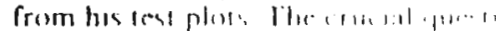

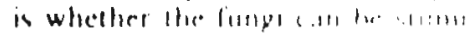

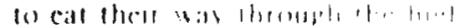

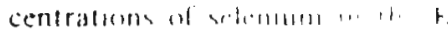
son soll fiat enomint

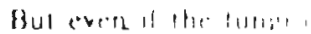

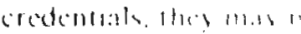

a carcfulls arourle amole "."

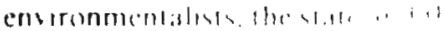

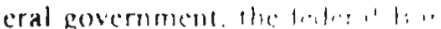

Reclamenen haw elisent: , .

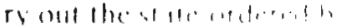

by Aupus las ."1,

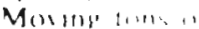

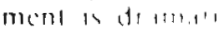

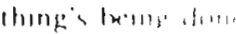

seroy the stle wh the or an

some lone for porete the b

tomed on the $1,1,1$ th.1 1 h.

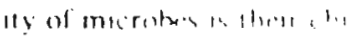


account for thic $400-\mathrm{km}$ discontinuity. The seismic anonisly at $400 \mathrm{~km}$ is due mostly to the relatively tast transition from olivine to $\beta$-spinel (19) because transformations from pyroxene to garnet are comparatively slow and occur over much larger intervals at depth. The xinolith data do not at present permit evaluations of the degree of heterogencity (centumeter to kilometer scale) in the mandle at thest depths, but much heterogeneity is predicred if oceanic slabs pile up in the transition tone $(20,21)$. Kimberlites are thought to be associated with mantle plumes (21), perhaps uriginating in the lower mande; therefore, xenoliths from, or with chemistries reflecting an origin deeper than, the transition zonc should be anticipated.

\section{REFI RENCES AND NOTES}

A. E. Ringu (nod, Composition and Perrology of the Eanh's Manth' (McGraw-Hill, New York, 1975).

2. J. D. Bass an. D. L. Anderson, Geophys. Res. Lea. 11, $237(19 \lambda t)$.

3. D. L. Ander wn and I. D. Bass, Nature 320,321 (1980).

4. F. I. Birch, Ceophys. Res. 57, 227 (1952).

5. D. L. Anders in, Spec. Pap. Mineral. Sac. Am. 3,85 (1970).

6. D. J. Weidrer, in Chemisty and Physics of Terressinal Plenets, S. $k$ ' Saxcra, Ed. (Springer-Verlag, New York, 1986), pp. 25!-274.

7. T. S. Duffy and D. L. Anderson, J. Geophys. Res. 94, $1895(2189)$.

8. S. E. Haggirty and V. Squuter, Science 248, 993 (1990).

9. H. Tsai, H. (1) A. Meyer, ). Moreau, H. J. Milledgc, in Procending: of the Second Kimberlice Conference, F. R. Boyd an! H. O. A. Meyer, Eds. (Anierican Geophysical Union, Washington, DC, 1979), vol. 1.pp. 16-20

10. R. O. Moute and J. J. Gurney, Nature 318, 553 (1985).

11. M. C. Wild11 ;, B. Hartc, J. W. Harris, paper presented at the 28 i I International Geologic Congress, 9 to 19 July 198 Washingtom, DG, vol. 3, pp. 359-360 (abstraci).

12. M. Akaogi 3s is. Akimoto, Phys. Earth Planer. Inter. $15,90(197)$.

13. For mafic cumpositions, the Si conrent in garnet increases conicomieantly with $\mathrm{Na}_{2}$ according to the coupled subs: Intion: (x) $\mathrm{N}_{2}{ }^{\mathrm{VIII}} \mathrm{SI}^{\mathrm{VI}}=\mathrm{R}^{24} \mathrm{~A}$. By contrast, for : iltramafic compositions the number of $\mathrm{Si}$ atoms and $\mathrm{M}^{2+}\left(\mathrm{C}_{2}, \mathrm{Mg}, \mathrm{Mn}_{3} \mathrm{Fe}^{2+}\right)$ increase in a complementary manner according to a second coupled subsinution: $(y)\left(\mathbb{R}^{2+}, S_{i}\right)^{v i}=(\mathbb{N}, \mathbf{N})^{v 1}$. For composicuons having borh mafic and ultramafic affinities, criupling of these rwo subsriturional schemes, $(x)$ and $(y)$, gives the following struccural formulac $(x)+(y) ;\left(\mathrm{Nz}_{x} \mathrm{R}^{2+}\right)\left(\mathrm{R}^{2+} \mathrm{Si}_{x+y}\right.$ $\left.\mathrm{R}^{3+}{ }_{2-2 y-\ldots}\right) \mathrm{Si}_{3} \mathrm{O}_{12}$. Reconstructed gamets. from group I having both affinities obey this complex structural formula. The compositional range of the $\mathrm{C}_{2}-\mathrm{N}_{2}$ majorte inclusions in diamonds from the Monastary nune (10) also corresponds to this double, coupled ubstitutional scheme.

14. This orientation would match the tetrahedral chains of $\mathrm{Si}$ in pyro enes with the octahedral sites of gamet that conuain both $S i$ and $\mathrm{N}$ under very high pres. sures ( $>80 \mathrm{k}$ bas) .

15. In a displacive cransformation, the product phase resuls generally from shearing of the preexisting mineral withuut bond breaking as observed in reconsunuctive transformation. Displacive transformations are fast under a suivable driving stress and are almost independent of temperarure (diffusionless).

16. T. Gasparik. Consrib. Mineral. Petrol. 103, 389 (1989).

17. M. Akaogi and S. Akimoro, Phys. Eanh Plenes. Incer. $19,31\left(197^{\prime \prime}\right)$
18. I. Irifune, T. Sekine, A. E. Ringwood, W. O. Hibberson, Eanh Planet. Sci. Lett. 77, 245 (1987).

19. F. Guyot et al., Grophys. Res. Leu. 18, 89 (1991).

20. A. E. Ringwood, J. Geol. 90, 611 (1982).

21. D. L. Anderson, Theory of the Eanth (Blackweil Scientific, Oxford, 1989)

22. Wo thank the DeBecrs Mining Company for access to Jagersfontein and logistical support. We ac- knowledge the comments by 1. D. MacGiregor and the anonymous reviewers. Supported under NSF grant EAR89.05\$046 (to S.E.H.) and the Centre National de la Recherche Scienutique for a grams from the INSU-DBT program, Theme 4: Fluds, minerals, and kinetics (to V.S.), contributson 252.

2 January 1991; accepred 5 March 1991

\title{
In Situ Biodegradation: Microbiological Patterns in a Contaminated Aquifer
}

\author{
Eugene L. MadSen, James L. Sinclair, " Willliam C. Ghiorse
}

Conventional approaches for proving in situ biodegradation of organic pollutants in aquifers have severe limitations. In the approach described here, parterns in a comprehensive set of microbiological activity and distribution data were analyzed. Measurements were performed on sediment samples gathered at consistent depths in aquifer boreholes spanning a gradient of contaminant concentrations at a buried coal tar site. Microbial adaptation to polyaromatic hydrocarbons (PAHs) was demonstrated by mineralization of naphthalene and phenanthrene in samples from PAH. contaminated, but not adjacent pristine, zones. Furthermore, contaminant-scimulated in situ bacterial growth was indicated because enhanced numbers of protozoa and their bacterial prey were found exclusively in contaminated subsurface samples. The data suggest that many convergent lines of logically linked indirect evidence can etfectively document in situ biodegradation of aquifer contaminants.

$\mathrm{T}$ HE RELEASE OF ORGANIC CHEMIcals to waters and soils can have dire consequences for wildlife, ecosystem integrity, and water quality (1). Alleviation of environmental pollution by stimulating native microbiological populations to effect biodegradation processes is promising (2), but such "bioremediation technologies" are far from proven. Although indigenous microorganisms in samples from many natural serings have been shown to have the potential to cffect pollutant climination $(3,4)$, the extent to which biodegradation potential is expressed in situ usually is a matter for speculation. Proof of in situ biodegradation must show that the mass of pollutant compounds has decreased and that microorgarisms are the causative agents. These two pieces of information are exceedingly difficult to obtain in a field setting because mass balances may be precluded by the open complexity of the site and because other abioric attenuating processes (dilution, migration, volatilization, sorption) may occur simultancously with biodegradation (5). In situ biodegradation has been documented successfully in field studies of ponds and soil plors (6), in which specific responses of microorganisms were distinguished from abiotic responses. In contrast, such studies

Section of Microbiology, Division of Biological Sciences, Cornell University, Ithaca, NY 14853.

- Present address: NSl Technology Services, R. S. Kert Laboratory, P.O. Box 1198, Adz, OK 74820. have: not been possible in ground-water aquifers because their inaceessibility and variability prevent implementation of replicated, statiscically valid experimental designs. Thus, studies that diretly and unequivocally demonstrate in sicu biodegradacion in aquifers are rare (7).

The majority of attempts to document in situ biodegradation in aquifers have used indirect observations. Typically an imperfecr mass balance, based on computer modeling, is cited to show loss of a pollutant in water pumped from the aquifer ( 8 ); but this approach does not distinguish unambiguously between biotic and abiotic processes. Chemical data from ground-water or sediment samples also may suggest that putative biodegradation activity is accompanied by changes in reacrants (for example, oxygen and nutrients) and products (tor example. $\mathrm{CO}_{2}$ or intermediary metabolites) which are indicative of known microbiological processes $(2,9)$. The case is strengthened if high numbers of microorganisms, especially of pollutant-degrading bacteria are found (2, 10). Further support may be garnered from laboratory biocransformation assays indicat. ing that the pollutant is chemically modified or converted completely to $\mathrm{CO}_{2}$ in samples from the site $(2,4,11)$. However, no established combination of these measures is robust enough to constitute absolute proof of in situ biodegradation in aquifer sediments. Methodological improvements are needed. We used patterns of microbiological activity 
ribution to indicate in siru biodegin a shallow aquifer contaminated ed coal tar.

neasured the potential of subsurface ganisms to degrade organic com. in aquifer sediment core samples d from a buried coal tar site (12) ) by aseptic subcoring procedures volution of ${ }^{14} \mathrm{CO}_{2} \cdot$ from the ${ }^{14} \mathrm{C}$. PAHs (naphthalene and phenan, and p-hydroxybenzoate (PHB) (14) easured (15). The abundance and tion of bacteria (including actino), fungi, and protozoa were assessed blished methods (16; 17). Core samere obtained from the unsaturated, table, shallow saturated, and deep ed subsurface zones in each borehole ig. 1). On the basis of previous site erization data (12), borehole locaere selected for collecting sediments anned a range of contaminant conions both horizontally and vertically. zalene and phenanthrene were detectamples taken from boreholes drilled the plume (Fig. I and Table 1), but samples from a pristine borehole the plume.

cralization of PHB was evident in nts from all three boreholes, but the $s$ from the upgradient borehole nearcoal tar were most active.(Fig. 2, A to the upgradient borehole samples, was no detectable lag period (18) the onset of biodegradation activity A). Downgradient in the plume PHB lization also was detected in all samut microbial metabolism was most and extensive in the sample from the table zone (Fig. 2B). A slight lag was noted in the deepest sample from urated zone. Three of the four sam-

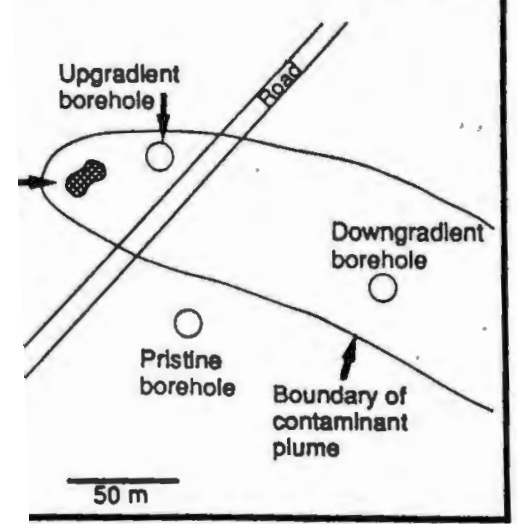

Jlan view of field site showing boundary minant plume and borehole locations. was buried 30 years ago (12). Groundiw has distributed coal tar components, 5. naphthalene and phenanthrene, sedimentary strata at depths between 1 3.
Table 1. Concentrations of PAHs. No maphthalene or phenanthrene detected in the pristine borehole; $\mathrm{BD}$, below detection.

\begin{tabular}{|c|c|c|c|c|c|c|}
\hline \multirow{3}{*}{\multicolumn{2}{|c|}{ Zone }} & \multicolumn{5}{|c|}{ Plume } \\
\hline & & \multicolumn{2}{|c|}{ Upgradient } & \multirow[b]{2}{*}{. } & \multicolumn{2}{|c|}{ Downgradient } \\
\hline & ' & $\begin{array}{l}\text { Naphthalene } \\
\left(m g \mathrm{~kg}^{-1}\right)\end{array}$ & $\begin{array}{c}\text { Phenanthrene } \\
\left(\mathrm{mg} \mathrm{kg} \mathrm{g}^{-1}\right)\end{array}$ & & $\begin{array}{l}\text { Naphehalene } \\
\left(m g \mathrm{~kg}^{-1}\right)\end{array}$ & $\begin{array}{c}\text { Phenanthrene } \\
\left(\mathrm{mg} \mathrm{kg}^{-1}\right)\end{array}$ \\
\hline Unsaturated & . & 0.06 & 1.6 & 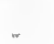 & $\mathrm{BD}$ & $\mathrm{BD}$ \\
\hline Water table & - & $\mathrm{BD}$ & 0.86 & $\because$ & BD & $B D$ \\
\hline Shallow saturated & & 2.3 & 0.33 & . & 0.24 & 0.35 \\
\hline Deep saturated & & 0.06 & $\mathrm{BD}$ & & 0.05 & $\mathrm{BD}$ \\
\hline
\end{tabular}

ples from the pristine borehole showed appreciable mineralization of $\mathrm{PHB}$, albeit with lag periods prior to ${ }^{14} \mathrm{CO}_{2}$ evolution (Fig. 2C). The water table sample was most active. No mineralization was observed in the deepest saturated zone sample from the pristine borehole.

Mineralization of naphthalene and phenanthrene was detected only in sediments taken from inside the contaminant plume (Fig. 2, D to G). All sediment samples from the pristine borehole failed to mineralize these PAHs during the 3-week incubation period. In samples from upgradient in the plume, naphthalene and phenanthrene were mineralized in all cases. The water table and deep saturated zones were most active (Fig. 2, D and F). Naphthalene was minieralized in three of the four samples taken from the downgradient borehole; again the water table zone sample was most active (Fig. 2E). Phenanthrene was mineralized only in the water table sample from the downgradient borehole (Fig. 2G).

There was often an inverse relation between the PAH concentration in sediments and $\mathrm{PAH}$ biodegradation activity for a given sample. For instance, neither of the PAHs were detected in the water table zone of the downgradient borehole (Table 1), yet PAH mineralization activity was high in these samples (Fig. 2, E and G). Furthermore, elevated levels of PAHs were detected in all shallow saturated zone samples (Table 1) where PAH mineralization activities were low (Fig. 2, D to G). These findings might be explained by small-scale sample heterogeneity or other sampling problems. However, it is also possible that the absence of detectable PAHs reflected zones of rapid in situ biodegradation (4) and that the presence of measurable PAHs reflected zones where rates of contaminant influx exceeded rates of microbiological mineralizarion.

Sediment samples were examined for the numbers and types of microorganisms pres-
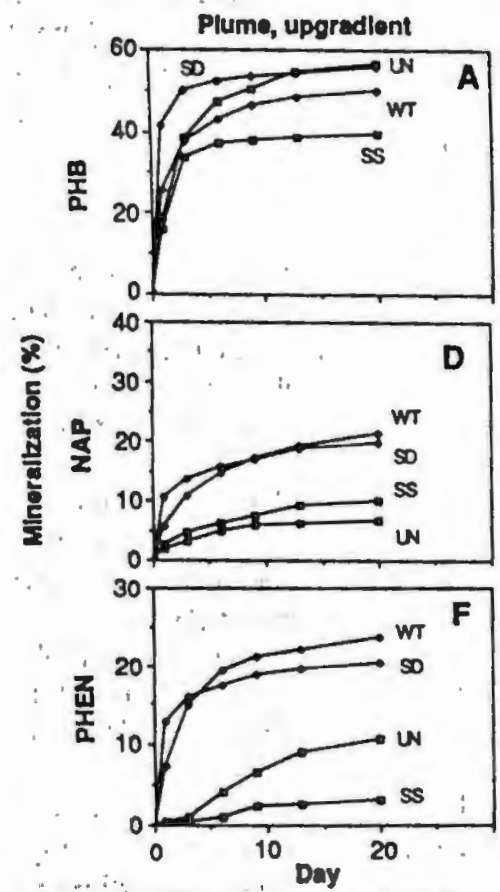

Plume, downgradlent

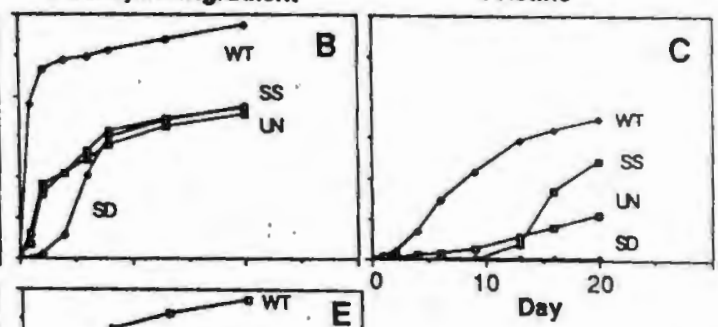

Fig. 2. Mineralization of organic compounds by subsurface sediment sam. ples. Boreholes were drilled at locations shown in Fig. 1. Sediments were obtained by aseptic tech. niques from equivalent geologic strata in four zones (13) within each borehole: unsaturated (UN), warer table (WT), shallow saturated (SS), and deep sarurated (SD). The samples were amended (15) with $p$-hydroxybenzoate (PHB), maphthalene (NAP), and phenanthrene (PHEN). Plots (A to $G$ ) are time courses of cumulative ${ }^{14} \mathrm{CO}_{2}$ trapped in triplicate flasks. No ${ }^{14} \mathrm{CO}_{2}$ was evolved in control flasks containing autoclaved, $\mathrm{HgCl}_{2}$-poisoned sediments. 
9. 3. Comparison of mibiological abundances in timents at four depths thin three boreholes. The ur depths examined were e unsanurated (UN), warable (WT), shallow satated (SS), and deep sarured (SD) zones. Each uster of three bars reprents numbers of microorgasms from samples inside c plume, upgradient eft); inside the plume, owngradient (center); and the prisine area (righr). (A) Viable bacteria, (C) actinomycetes, and (D) fungi were determined by ie plate-count method (16). (B) Total bacteria were determined by epifluorescence microscopy (16). E) Protozos were enumerated using Enterobacter aerogemes as prey bacteria (17).

nt (Fig. 3). Viable counts of aerobic heteroophic bacteria showed a consistent pattern; ney were highest upgradient, inside the lume, closest to the source of contamination nd lowest in the pristine borehole (Fig. 3A). Licroscopic counts for total numbers of baceria were 100 - to 1000 -fold higher than the iable counts (19) and showed the same leclining trend with depth, but only small lifferences were observed between prisane und contaminated samples (Fig. 3B). Actinonycetes were found in significant numbers $\geq 10^{3}$ per gram of sediment; Fig. 3 C) in wo-thirds of the unsarurated and water table zone samples. Low numbers of actinomycetes were detected in saturated zone samples. Low zumbers of fungi also were present in subsurace sediments; only small differences were ound between samples regardless of depth or sorehole location (Fig. 3D). Similar low umbers of fungi and actinomycetes have xeen found in other shallow and deep suburface sites $(16,17)$. In contrast to fungi, rotozoa (amoebac and flagellates) showed a criking range in abundance (Fig. 3E). High irotozoan numbers were found in several amples from unsarurated and water table ones within the contaminant plume. The pgradient plume borehole contained more tan 400 protozoa per gram in both the nsaturated and water table zone samples. his is a relatively high population density for absurface protozoa (17): In the downgradint borehole, the water table zone sample ontained more than 19,000 protozoa per ram, a number far above those normally zcountered in shallow aguifer sediments 17), but comparable to those found in actiated sewage sludge facilities (20). The water ble zone sample that supported a high ensiry of protozoa was highly accive in minalizing the three compounds examined ig. 2, B, E, and G): Another recent srudy is also reported the occurrence of large unbers of protozoa in subsurface sediments nere jet fuel vapors commingled with atmoheric oxygen (21). Typically low numbers of protozoa ( $<50$ per gram) were present in all samples from the pristine borchole and in saturated sediments from just below the water table within the plume of contamination. Sediments from deeper in the sanurated zone were not examined for protozoa.

The mineralization activity and microbial discribution parterns observed in this study are likely to be controlled by sparial heterogeneity of sediment properties such as texture and hydraulic conducivity (22), as well as by the presence or absence of carbon and energy sources provided by coal car components in the ground water. Even though sedimentary characteristics of this study site were relatively uniform (12), it is impossible to be certain that the sediment samples obtained from four depths of each borchole were derived from hydrogoologically equivalent surata. In an artempt to separate the influence of aquifer sediment heterogeneity from that of PAH contamination, we obtained vertically and horizontally separated samples from zones of high and low PAH concentration and sought patterns in the microbiological data. The significant parterns were as follows: (i) PHB mineralizing microorganisms were present throughout the site; however PAH mineralization activity was resuricted to samples from within the plume of contamination; (ii) samples from all depths in the upgradient borchole mineralized both PAHs, whereas several samples from the downgradient borehole were inaccive; (iii) lag periods prior to mineralizacion were observed only in downgradient and pristine samples; (iv) viable bacteria were detected in greatest abundance in samples from the upgradient plume borehole, whereas the lowest abundance was found in samples from the prisaine borehole; and $(v)$ elevared numbers of protozoa were found in unsarurared and water table zone sediment samples from within the conmaminant plume which conained active populations of PAH-degrading microorganisms. The obvious conclusion from these results is that microbial distriburion and adaptacional biodegradation activity (23) in this polluted aquifer system were governed by proximity of the source of PAH contamination.

Protozoa are important predators in aquatic and terrestrial environments (20), but only recently has it been established that prorozoa also are widely distributed in subsurface sediments (17). The concepr of using protozoan abundance as an index of pollution dates from the early part of this century (24). In fact, associations between protozoan abundance and high levels of organic carbon in soil or municipal waste water are well established (25). However, studies examining interactions between organic contaminants and protozoa are rare (21). Data derived from coastal feld samples and laboratory-incubated soil cores indicated that crude oil was inhibitory to protozoa $\left(26_{\text {A }}\right.$ 27). In contrast, another laboratory study found that a ciliate protozoan enhanced microbial degradation of crude oil (28). Until now field evidence for the biogeochemical funcrion of subsurface protozoa, which usually are found at low popula. tion density, has nor been obtained. The population density of protozoa usually reflects the rate at which they are able to graze on their bacterial prey (20). A high protozoan grazing rate is indicated by a high population density. This in turn reflects a high bacterial growth rate rather than increased bacterial biomass. The dependence on bacterial growth rate has been shown in sewage treatment plants where high numbers of protozoa are able to reduce viable counts of bacteria while simultaneously accelerating carbon cycling and increasing their own biomass (20). In this study, elevated numbers of protozoa occurred exclusively in sediment samples from upper zones of the subsurface profile where contaminants and oxygen would be expected to mix. The high protozoan numbers are indicarive of rapidly growing populacions of bacteria in siru. To the extent that prey are growing on contaminant compounds, the elevared protozoan biomass reflects in siru biodegradation activity. Thus, we have compelling indirect evidence for in situ biodegradation of organic contaminants in aquifer sediments: (i) protozoan biomass indicates in siu growth of prey bacteria and (ii) adaptational biodegradation activity indicates that the prey bacteria are growing in response to contaminant compounds.

\section{REFERENCES AND NOTES}

1. F. Morianty, Erotaricology: The Siudy of Pollucants in Ecosystems (Acadernic Press, London, ed. 2, 1988); J. F. Piart et al., Auk 107, 387 (1990).

2. M. D. Lecer ol. CRC Crit. Rev. Environ. Cont. 18 , 29 (1988).

3. J. G. Leahy and R. R. Colwell, Microbiol. Ren. 54, 305 (1990).

4. J. T. Wilson es al., Environ. Toxicol. Chem. 4, 721 
85); J. M. Thomas et al., J. Ind. Microbiol. 4, (1989).

Cooney, in Petroleum Microbiology, R. M. Actas, (Macmillan, New Yort, 1984), Pp. 399-433; G. odgare, in ibid., pp. 355-397; D. M. Karh in teris in Nasure, J. S. Poindexter and E. R. Leadter, Eds. (Plenum, New York, 1986), pp. 85-176 C. Spain et al. . Appl. Envirom. Microbiol. 48, 944 884); R. L. Raymond, I. O. Hudson, V. W. nison, Appl. Environ. Mirrobiol. 31, 522 (1976). e feld study by L. Semprini et al. [Ground Water , 715 (1990)] is exceptional. Is success can be ributed to field instrumentation, a shallow coned aquifer, and the simulaneous merabolism of ygen, methane, and chlorinated ethenes.

C. Borden and P. B. Bedient, Water Res. Bull. 23, 9 (1987); C. Y. Chiang et al., Ground Wauer 27, 3 (1989).

V. Cline and D. R. Viste, Waste Manage. Res. 3 , 1 (1985); F. H. Chapelle and D. R. Loviey, opl. Environ. Microbiol. 56, 1865 (1990).

W. Federle and G. M. Pastwa, Ground Water 26, 1 (1988); H. F. Ridgeway et al., Appl. Environ. icrobiol. 56, 3565 (1990). Microbial couna do t necessarily reflect in siru metabolic activity

M. Klecka ef al., Ground Waser 28, 534 (1990); . C. Ghiorse and J. T. Wilson. Adv. Appl. Micro1. 33, 107 (1988). Laboratory daca describing odegradation of various organic chemicals [M. exander, Science 211, 132 (1981); W. C. Evans, alune 270, 17 (1977); J. F. Quensen, J. M. Tiedje, A. Boyd, Seience 242, 752 (1988); S. Dagley, arv. Prog. Chem. 8, 121 (1977)] show that microganisms in soil and water have the potencial to ralyze chemical reactions. However, microbial acvity in disturbed environmental samples contained - laboratory versels cannot be equated to in siru tivity (5).

oal ar is a black material produced from coal asification proces - $s$ II. F. Villaumc, in Hozandous id Taxic Wastes: : rchnology Management and Healsh feects, S. K. Ma! indar and $E_{t}$ W. Miller, Eds. ennsylvania Aca letny of Science, Eastom PA 984), pp. 362-3: i). A single truckload of coal tar as buried in a Fi rested area in the northeastem Inited States. This ire has been characterized under PRI research pro 'cts 2879.1 and 2879-12 [B. B. aylor et al., in Po recedings: Environmental Research onference on Grourdicuater Quality and Waste Dispos. (Electric Power Research Insticute, EN-6749 alo Ato, CA), pp. 26-1-26-12]. Sedimenes were 3 to $99 \%$ sand. Subsamples of materials used in odegradarion assays were analyzed for PAHs by Ls chromatography (GC) and GC/mass spectromry by Cambridge Analytical Astociates, Inc., Bos. in, MA under EPRI contract 2879. I

septic coring procedures followed established prinples $(2,4,16,17)$. Depths selected for anslyzes ere 1 to $2 \mathrm{~m}$ (unsaturared zone), 2.3 to $3 \mathrm{~m}$ (water ble incerface), 4 to 5 , and 5 to $6 \mathrm{~m}$ (shallow and :ep saturated zones). Additional decrils appear in PRJ Final Report RP 2879.5.

$\because B$ is an intermediary metabolite in lignin biodeg. dation [J. P. Martin and K. Haider, in Lignin adegradation: Microbiology, Chemistry, and Potential oplications, T. K. Kith, T. Higuchi, H. Chang, Eds 次C Press, Boca Raton, FL, 1980), vol. 1, pp. - 100 ] that is mi-abolized by many acrobic soil cteria.

Jnversion of ort nnic compounds to inorganic mpounds (miner lization) was measured by scanrd ${ }^{14} \mathrm{CO}_{2}$ tral sing methods. Radiolabeled .${ }^{14} \mathrm{C}$ )naphthalene $(80 \mathrm{mCi} / \mathrm{mmol},>98 \% \mathrm{r2}$. spurity), $\left[9 .{ }^{14} \mathrm{C}\right]$ heranthrene $(10.4 \mathrm{mC} / \mathrm{mmol}$, $39 \%$ rdiopurin, and p-hydroxybenzonte (ring L $7.7 \mathrm{mCi} / \mathrm{mmol}$, $>99 \%$ radiopurity) were purased from Sigma Radiochemicals (St. Louis, O). Compounds were dissolved, filter-sterilized aphthaiene and shenanthrene in acetone before ig diluted 100 -fold in dirrilled water, $p$-hydroxynzoate in distilled water) and then added to sterile 5-ml lasks contrining $4 \mathrm{~g}$ of aseptically distributed timent sample. Fich flast received $0.04 \mu \mathrm{Ci}$ of Z-labelod and wilabeled naphthalene, phenanene, or p-hydrox tenzoate at concentracions of 1 m. An abiotic co itrol llask was prepared in each $t$ by auroclaving the sample for 1 hour and adding I $\mathrm{ml}$ of $1 \mathrm{M} \mathrm{HgCl}_{2}$ before addition of carbon compounds. The flasks were sealed with lids suspending a small plastic cup (containing $0.6 \mathrm{ml}$ of $\mathrm{CO}_{2}$ trapping agent) and incubated statically at $23^{\circ} \mathrm{C}$. At each sampling time, trapping agent was withdrawn, counted in a scinillacion counter, then replenished.

16. D. L. Balltwill and W. C. Ghiorse, Appl. Environ. Mierobiol. 50, 580 (1985); J. T. Wilson et al., Ground Water 21, 134 (1983).

17. J. L. Sinclair and W. C. Ghiorse, Geomicnobiol.J. 7 , 15 (1989); Appl. Environ. Microbiol. 53, 1157 (1987)

18. T. D. Brock and M. T. Madigan, Biology of Microonganisms (Prentice-Hall, Englewood Clifts, NJ, ed. 5,1988 ). Lag periods occur when enzyme synthesis or population growth precede biodegradarion; their absence indicates a state of metabolic readiness.

19. Total counts normally exceed viable counts by 2 to 3 orders of magnitude [D. B. Roszak and R. R. Colwell, Microbiol. Rev. 51, 365 (1987); (16, 17)].

20. T. Fenchel, Erology of Provesosas (Scicinoe Tech, Madison Wh, 1987); W. Foisener, Prog. Protived. 2,69 (1987); J D. Stout, Ady. Micrabiol. Ecol. 4, 1 (1980).

21. I. L. Sinclair, in Proceedings of the First Intemational Symposium on Microbiology of the Deep Subsurface, C. B. Fliermans and T. C. Hawen, Eds. (WSRC Information Services, Aiken, SC, 1991), Pp. 3-35-3-45.

22. S. N. Levine and W. C. Ghiorse, in ibid, PP.
5-31-5-45; J. K. Fredrickson et al. , Geomirrobiol. J. $7,53(1989)$

23. Adaptational biodegradation is indicared by an ac celeration in microbiological descruction of chemi. cals after their introduction into a given environment $(3,4)$. Adaptation has been reported in subsurface microbial communitics to $\mathrm{PAHs}(4)$ and in other setrings (3).

24. R. Kolwitz and M. Marsson, Ine. Rev. Hydrobiol. Hydnog. 2, 126 (1909) [cited in Fenchel (20)]

25. H. T. Tribe, Soil Sci. 92,61 (1961); C. R. Curds, Annu. Rev. Microbiol. 36, 27 (1982)

26. E. Hartwig, Senckenbergiano Marit, 16, 121 (1984) [cited in Foissner (20)].

27. J. R. Vestal et al., in Petroleum Mierabiology, R. M Atlas, Ed. (Macmillan, New York, 1984), pp. 475 505.

28. A Rogerson and 1. Berger, I. Gen. Appl. Microbiol. 29,41 (1983):

29. We thank B. B. Taylor and J. A. Ripp for collabometive field assistance and analytical data that were obeained under EPRI contract 2879.1. This investigation was carried our under EPRI projec RI 2879-5. Techrical 2ssistance from L. Anguish. S Best, C. Thomas, and A. Winding is gratefully acknowledged.

13 November 1990; accepred 13 March 199]

\section{Control of doublesex Alternative Splicing by transformer and transformer-2 in Drosophila}

\section{KazUYYKi HoshiJima, Kunio INOUE, IKUKo HIGUChI, Hiroshi Sakamoto, Yoshiro ShImUra*}

Sex-specific alternative processing of doublesex (dsx) precursor messenger RNA (pre-mRNA) regulates somatic sexual differentiation in Drosophila melanogaster. Cotransfection analyses in which the $d s x$ gene and the female-specific trensformer (tra) and transformer-2 (tra-2) complementary DNAs were expressed in Drosophila Kc cells revealed that female-specific splicing of the $d s x$ transcript was positively regulated by the products of the tra and tra-2 genes. Purthermore, analyses of mutant constructs of dsx showed that a portion of the female-specific exon sequence was required for regulation of $d s x$ pre-messenger RNA splicing.

S OMATIC SEXUAL DIFFERENTUATION DN Drosophila melanogaster is accomplished by a hierarchy of regulatory genes that act in response to the number of $X$ chromosomes relative to the number of sets of autosomes in a cell (the X:A ratio) (1). One of these regulatory genes, dox, is required for terminal sexual differentiation in both male and female flies (2): Molecular analyses have shown that the dor transcript undergoes sex-specific RNA processing (splicing and cleavage-polyadenylation reactions), which leads to the production of two distinct sex-specific polypeptides (Fig. 1A) (3). The male- and female-specific dox products regulate sexual differentiation by repressing the female- and male-specific terminal differentiation functions, respectively

Departiment of Biophysics, Faculty of Science, Kyoro University, Kyoto 606, Japan.

"To whom correspondence should be addressed.
(2). Genetic analyses have shown that the tra and $t r a-2$ genes are required for regulation of sex-specific dox expression (4). In males, tra produces a nonfunctional product, whereas the female-specific tra product is functional and is produced by alternative splicing of tra pre-mRNA $(5,6)$. The tra-2 product is also required for proper differenciation of male germ line cells (7). The predicted polypeptide encoded by tra-2 (8) contains a domain of 90 amino acids that is also found in RNA binding proteins (9). In addition, the predicted protein sequences encoded by tra-2 (8) and tra (10) contain arginine- and serinerich regions that are characteristic of proteins that participate in RNA processing (9) Although these findings suggest that the products of tra and tra-2 function in the regulation of alternative processing of $d x x$ pre-mRNA, direct evidence has been lacking.

To decipher the mechanism of alternative processing of $d s x$, we constructed a plasmid 


\title{
Aerobic Biodegradation Potential of Subsurface Microorganisms from a Jet Fuel-Contaminated Aquifer
}

\author{
C. MARJORIE AELION 1.20 aND PAUL M. BRADLEY'."

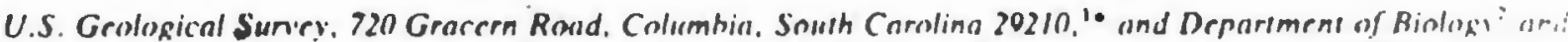
Marine Sciences Program.' Uniuersity of South Carolina. Collumbin. South Carolina 202a4

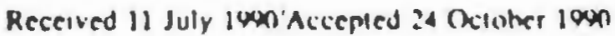

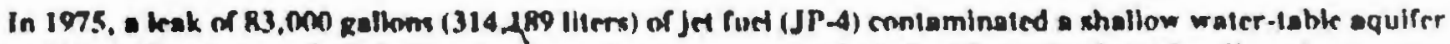
mear North Charteston, S.C. Latoraton yxperiments were conducted with contominated sediments to ascrss the acroble biodexradation pokential of the in situ mictohial community. Sediments were incubaind with "C-lateled organle cmpounds, and the evolution of " ${ }^{14} \mathrm{O}_{2}$ wos measured over $1 / \mathrm{me}$. Gas chmmatortaphic

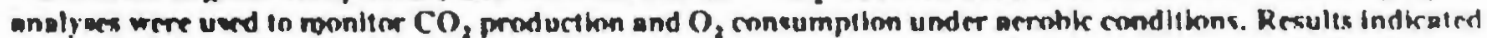

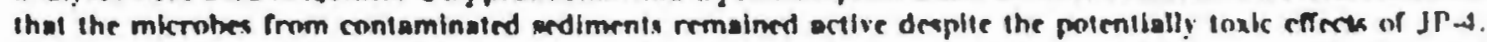

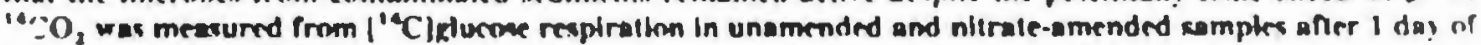

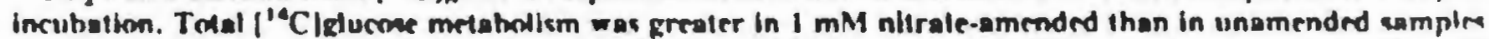

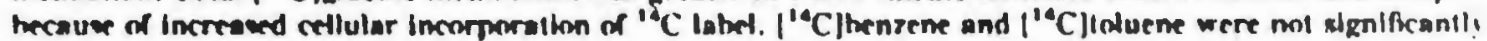
repiret aner 3 monthe of incutation. Wilth thr addition of $1 \mathrm{mM}$ NO.. CO, production mewsured hy gas

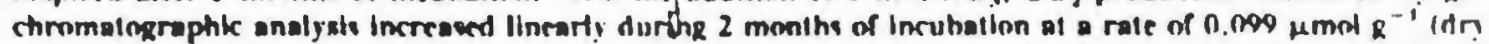
wrtght) day while oxigen concentrallon decteoud at a rate of $0.124 \mu \mathrm{med} \mathrm{g}^{-1}$ (dry wetght) day ${ }^{-1}$. Wilh nn

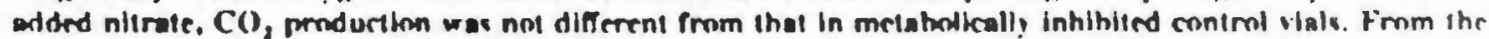

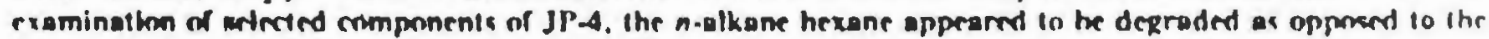
hranched alkanes of similar motecular welzht. The resules sugaest that the in allu mbernhtal communtl, is active dreplite the JPA Jet fort motamination and that biodegradation may the compound sperific. Also. The

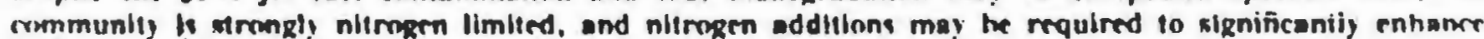
hyditucartion Hadegradation.
\end{abstract}

Curtent cfforts to remediate suhsurface conisminntion have spurred rescarch in the applicarion of in silu hioreme. diation. Demending on specific hydrogeologicnl, microbio. lugieal, in l chemical constraints, in sttu hiodermdntion of orranic contaminants has heen surecsied as a cost-eflective and enviruamentally sound remedintion allemntive Io pump. and-irent ind veruum-extraction technologies. Before an in situ hioremedintion project can the implemented. n feasibility study is required to nssess the exlent und lype of contami. nation, the hydrogedogy of the site, and the netivity of the microbinl community and its cnpability to degrade the con. inminants if concern.

Several laturmiory studios have examined the capnhility of microorrantsms to degmde orgnnic solvents (4, 9). pesticides (16). and pitroleum hydrocattons (22). Peiroleum hydrocartwons nre well suited to hislogicint irestment, and in situ hiorrmedianon has heen allempled movt frequenlly on this 1) pe of contamination (12). Buth nerohic $11,5,2(1)$ and Inuerobic 17, 10, 14) biodegrndmion have heen shown 10 reduce the concentmition of severnl componenis of peiro)leum hydrecentinns. This is particularly encournging in light of the potential for widespred petroleum contaminnlion of subsurface mnlerinl from lenking underground and nlove. ground stompe innks at sites ncross the United Stules.

The present investigation was undertalen to exnmine the micrubial communily of a shallow whter-lahle nquifer nen Nornh Chuteston, S.C., which was coninminuted in 1975 when the nhoveground storage lank no. I leaked H3,(m) eallons (1 gallon - 3.785 liters) of JP-4 jel fuel (IPig. 11. - Approximicly 21,000 gallons of the fuel was recovered by

\footnotetext{
- Comermindin author.
}

1976. but 75\%, remnined in the sutheurface environment, 1...1

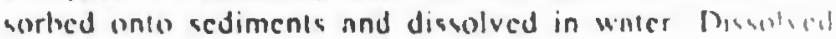
concentrations of henzene, loluene. ethyltenzene, am! $1,4 !: 11$

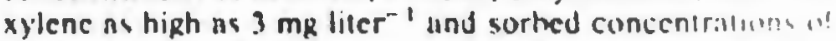
total metroleum hydrocartions of $4.000 \mathrm{mR} \mathrm{mer} \mathrm{kg}_{k}$ (1) $\mathrm{dr}$ sediment (15) have teen mensured at the site. Fiperumenes were carried out to examine whether the microhinl cunumll. nity was active despile the substantial contaminatlun prewens or aliernalively if the JPA in the henrt of the plesme Wis , is to the microorgnnisms. Also, the biodegrndntive putent it if the in silu microtinl community to degrade ihe lwa i. molecular-weight components $\left(C_{\text {, }}\right.$ to $C_{\text {P }}$ ) of the Jl.4 int the infuence of nitroren suditions on microtinl ncliwls : $1: 1$ ! meinholism were nescsed.

\section{MATERIAIS AND METHON}

Sutwurface mamples. The aquifer mnterial used in 1 his stuh whs collecled aseptically from the contaminnted alquils in North Charteston. S.C., in March 1489 and sfored ill of " until incubntions were hegun. The shallow wnler-luhle :1full. fer nt the site consists of sediments of medium-grnined sinds whin interfingering lenses of clay to a depith of approximitrls 20 to $35 \cap$ (1 $n=30.48 \mathrm{~cm})$. Underlying these sedimenla in $n$ formation cunsisting of predominantly clay material. I hr. depth to the waler intic varick aenconally but is npprin. mately 5 10 14 n helow. Innd surtace. Experiments " carrice out hy using sediment from the suturnted rone. collected ut a denith of 12 to $20 \mathrm{n}$.

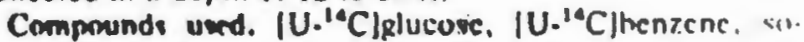

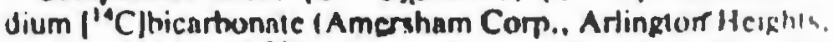
III.), and [ring-U. "Cloluene (Sigma Chemica] Co.. Si Louis. Mo.) with specific activities of 270,121 . 5. and $8, ?$ 


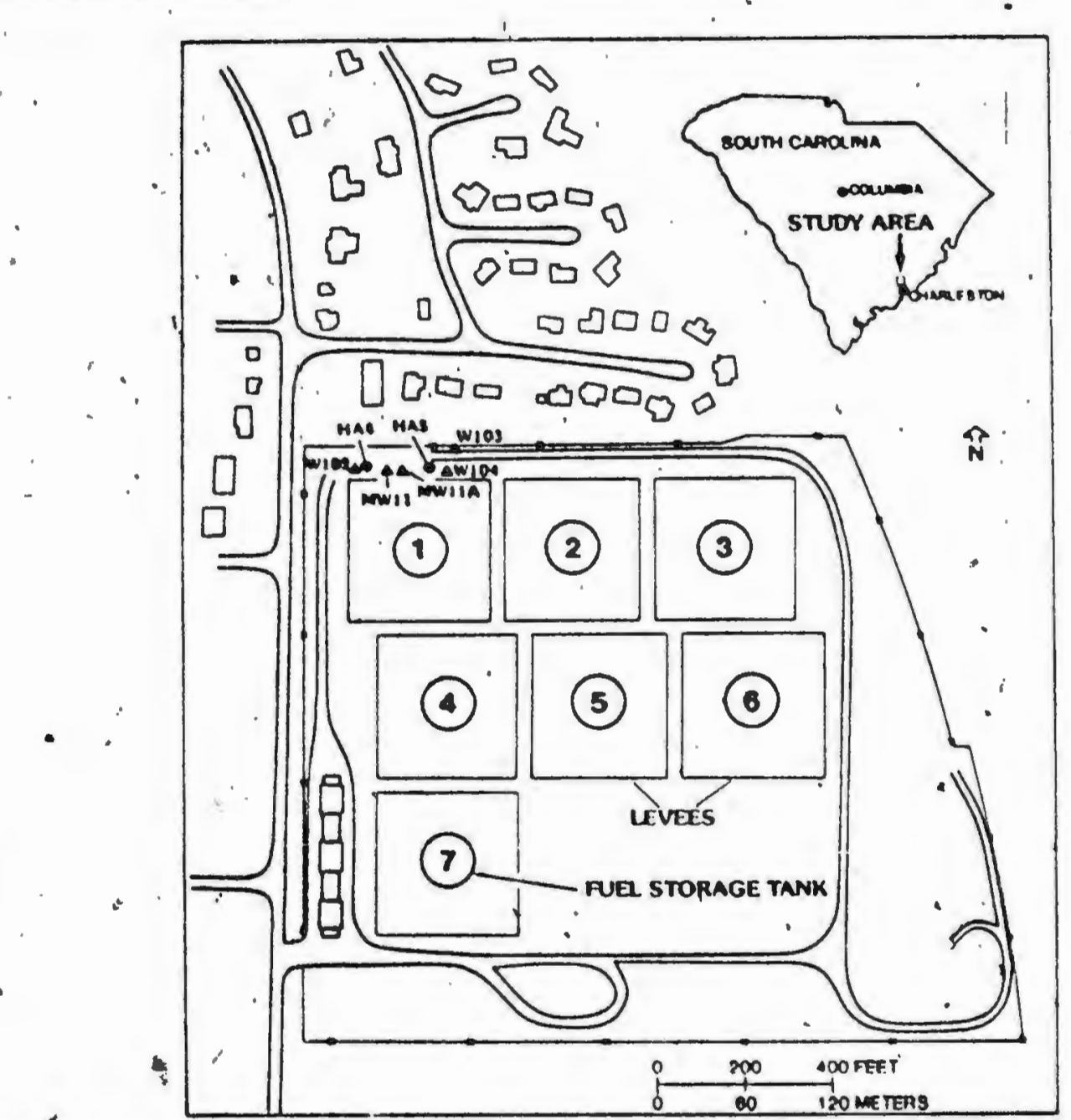

F10. A. Site man showing apmoximate location of study nerea and locations of monitoring well (A) and kediment sample (O) sites

mCinmol, respectively, were used in this study. Inurgnnic nutrient induded $\mathrm{Ca}\left(\mathrm{NO}_{3}\right)_{2}$. $\mathrm{NaNO}_{1}$, and $\mathrm{Ca}\left(\mathrm{H}, \mathrm{MO}_{1}\right)_{2}$. SO dium arioc $\left(N^{-} N_{3}\right)$ was used as.a metabolic inhibitor of serobiórespirution (Sigma).

Fete' of "C-radtalaberted leokopes. The soses bnlnnce and retpiration of unganic substmles were meawured by using a modification if the procedure deacribed by Dobbins and Pracender (6). Iur all incubalions, a mample of 3 g (dry weighl) of aquifer malerial trom the boring designaled HA4. frum a demh, of approximately $121020 \cap$ (F/g. I), was weighed inlo a 20-ml glaus vial (Pienic Chemicnil Co.. Rockville. Ill.). und npnodximatels $10 \mathrm{ml}$ of slerilized, diatilled wnier wax ndded. Rendiolabeled substrate and inorganic nutrient amendments wers then adiled to,all of the umples, and the remaining volume was flllod with sterile, distilled water lenving no tiendenace. For l'Clelucoso, the vinis were senled with Tellontinod septa and cappod. Samples were, Inverted und incubylod in the dark at room lemperalure. For the mure

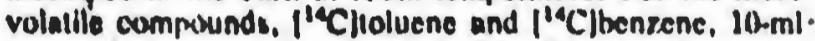
cerum vials Here unod and soalod with nuther butyl utoppery and aluminumi crimp caps. Melatrolically inhibiled coniry viais wero incaiod similarty is.exporimentul vials but wert" ameniled will $\mathrm{NaN}_{1}$ to 月 Anal conceniration of $0.5 \%$.

Anat incutiation, lice unniplos wero inniferred $1040 \mathrm{ml}$ vials hy using Teflon connector enps (Whellon Scicntilic Co.. Millville. N.J.). The samples were ncidified wilh IH,IP(, 11) a $\mathrm{pH}$ of 2 und shaken overnight on a rulary shaker. anif ilu ${ }^{3} \mathrm{CO}$, was collected in a $\mathrm{KOH}$ base tmp in the vial head. spence. Respirmtion values were correcicd for nhiolic comlis futions by subiracting values for the meinbolicnlly inhihitcel control vials. The efficiency of the ${ }^{19} \mathrm{CO}_{2}$ recovery melhuil was measured by manns of $\mathrm{NaH}^{14} \mathrm{CO}_{1}$ control vinls, prex. essed in a manner similar to that used for the sumpic vials but with $\mathrm{NaH}^{14} \mathrm{CO}$, ndded instead of the ${ }^{14} \mathrm{C}$-Inbeled urkinsis compound. After correcling for abiolic processes and ${ }^{14}(\%)$ recovery. the perecninge of the substrute minerilized wits calculated.

Alfer the " $\mathrm{CO}_{2}$ recovery was compleled, "I mnss halunice delermination was carried out on the remaining sedinien and filimie. For this procedure, the amounts of " ${ }^{\circ} \mathrm{C}$ mi:" sured as ${ }^{14} \mathrm{CO}_{2}$, associated with cellular biomnss, jossivinte. with sediment, and present as a soluble fraction in the filtrite were delermined (6). Cells were removed from sedimen! purticles by using im washing, shaking, centrifuging. "mul fllering procedures. The first wash used a mixture of sidum pyrophosphnte and polyvinyipyrrulidone (final concentı: lloin, 0.1 and 1.0\%, renpectively), and the second used: colution of hydrogen peroxide (find concentration, $0.1 \%$ ). 
TABI.E 1. Compounds identified in vial headspace by coelution with gas chromatopraphic standard 1

\begin{tabular}{|c|c|c|}
\hline compound & 1 & $\begin{array}{l}\text { Retention } \\
\text { lime (min) }\end{array}$ \\
\hline \multirow{2}{*}{\multicolumn{2}{|c|}{ 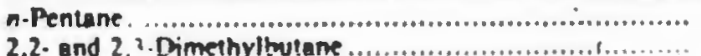 }} & \\
\hline \multirow{2}{*}{\multicolumn{2}{|c|}{ 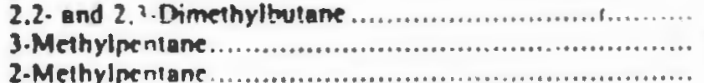 }} & h. \\
\hline & & 10 \\
\hline \multirow{5}{*}{\multicolumn{2}{|c|}{ 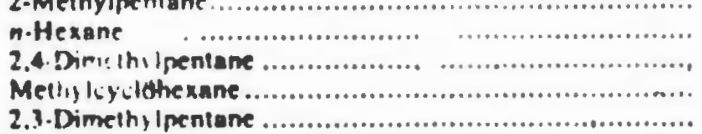 }} & 11. \\
\hline & & 17 \\
\hline & & 2.1 \\
\hline & & 20. \\
\hline & & . 24.19 \\
\hline
\end{tabular}

Ges chmmatopraphk andyees. $\mathrm{CO}_{2}$ produclion. $\mathrm{O}_{2}$ con. sumption, and hydrocarton disappearance, were monitured by using gas chromatopraphy. For $\mathrm{CO}_{2}$ and $\mathrm{O}_{2}$ conceniralions monitored over lime. $125 . \mathrm{ml}$ serum vials were filled with 50 of sediment collected from a depth of approxi. mately is in $20 \mathrm{n}$ from the boring designated HAS (Fig. 1). Two replicm es were used for each condition. A $2-\mathrm{ml}$ volume of aulociased liquid was added to cach vial. cither as distilled water in unamended samples or as inorganic nutri. ent solution in nitrate-amended samples. Sudium azide uas used 10 crente duplicaic meinholically inhibited control samples. Arproximalcly $2 \mathrm{ml}$ of gas in the vial headspace was withdriwn through a Teflon Mininert valve (Supelco. Bellefonte, $\mathrm{Pa}_{\mathrm{a}}$ ) und injected into the pas chromatograph vis a fixed-volume sinmple loop. The volume of gas that whs withdrnwn was replaced with atmospheric nir. and this dilution effect.was sccounted for in calculations of constitu. ent concentration.

Severnl compounds were identified in the gas in the vinl hendspace hy coclution with chromajographic standards (Table 1). The mnge of compounds included primnrily $C$, w C. hranched and nomal oliphatic compounds." The disapprarince of these compounds was monilored in $125 \cdot \mathrm{m}$ ] renim vials cuntnining $100 \mathrm{~g}$ of sediment under the following combunons: sediment metaholically inhibiled with $\mathrm{NaN}_{1}$. - liment with adjed nitmie $(28 \mathrm{mM})$, and sediment with

' 1 nitrate $(28 \mathrm{mM})$ and phosphate $(4 \mathrm{mM})$ and in a JP-4 ' trd control consisting of $10 \mu \mathrm{l}$ of $\mathrm{JP}-4$ jet fuel in $\$ 1 \mathrm{ml}$ ". illeclaved, distilled wenter. The snmples were processed in iescribed atrove except that the hendenace that whs removed uas not replaced. Reductions of individunl compo. nents of JP-4 a.ere calculated as n pereentape of the mito $\left(C_{1} / C_{1}\right)$ of concentration at time $\left(C_{1}\right)$ to initial concentration $\left(C_{n}\right)$. Cartoon dioxide and oxyren nlso were measured nfter aproximatcly IM days of incutalion.

All $\mathrm{O}_{2}$ and $\mathrm{CO}_{2}$ nnalyses were carried out with a Carle AGC.111 ans chnomatograph (Hach Co.. Anaheim. Calif.) equipned wilh a thermal conductivity detector and n stainless-ateel (Hoyesep A. $507(0)$ nnalytical column ( $v_{n}$ in. I $\mathrm{co}$. $0.32 \mathrm{~cm}$ | by. $\mathrm{k}(\mathrm{)})$. Helium. $\left(22 \mathrm{~cm}^{\prime} \min ^{-1}\right.$ ) was the carrice RAs,

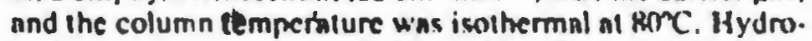
cartion analyses were carried out with a Carte AGC.211 Ras chromatogmpli equipred with n Anme ioniration Jeteclor and a glass column (K in. by 6 fil $(11.1 \% 5 P \cdot 1000$ on $80 / d M$ Carbonack C). Helium (42 $\mathrm{cm}^{\prime}$ min $^{-1}$ ) was the corrier gns. hydrogen (25 $\left.\mathrm{cm}^{1} \mathrm{~min}^{-1}\right)$ wav the detector pas, and com. mened nir (s) $\left.\mathrm{cm}^{\prime} \mathrm{min}^{-1}\right)$ whe the fuel prs. Column

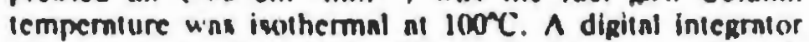
(Hewletl-Pachard mudel 3.3以0A) wav uved to quantify menk aresa. Quantilintive alandand for hydrocartoons were pur. chaned frum Supcleo, and those for $\mathrm{CO}_{2}, \mathrm{O}_{2}$, and $\mathrm{CH}_{4}$ were
TABLE 2. Tósal retroleum hrdrocartion (TPHI concentmitions in selecied sediment sumptes from March 1909 (1s)

\begin{tabular}{|c|c|c|}
\hline $\begin{array}{l}\text { Sampte } \\
\text { m. }\end{array}$ & $\begin{array}{l}\text { Sampine } \\
\text { dermh (II) }\end{array}$ & $\begin{array}{l}\text { TPH comsn } \\
\text { ine } 4 . \text { ' (dry wi) }\end{array}$ \\
\hline$H A 43$ & 9 & 13 \\
\hline HASA & 13 & 15 \\
\hline HA4.5 & 16 & 14 \\
\hline HAAh & 22 & 18 \\
\hline HA4-7 & 27 & 19 \\
\hline HAS.? & 10 & 92 \\
\hline HASA & 14 & 252 \\
\hline HA.5.S & 17 & 655 \\
\hline HAS-6 & 21 & 38 \\
\hline HА5.7 & 26 & 47 \\
\hline
\end{tabular}

purchased from Scolty Snecialty Gases IPlumsteadvilis. Pî.).

\section{RFSULTS}

Groundwater sampled in the aren of the spill (Fig. 1) contained concentations ranging from 0. 009 (well MHill) to 0.56 (well W102) $\mathrm{mg}$ of benzene per liter, 0.003 (well W103) to 0.51 (well WIO4) ing of loluene per liter, 0.003 to 0.27 (well MWI1) $\mathrm{mg}$ of ethyltienzene per liter, and $0.00 R$ (well $\left.W^{\prime}\right] 0.3$ ) lo 1.3 (well W102) mg of tolal xylene mer liter (1R). Values for total organic carbon ranged from $71052 \mathrm{mg}$ per liter. specific conducinnce ranged from $10 \$$ to $170 \mathrm{mg}$ per liter. $1 \mathrm{empem}$. ture manged from $19 \mathrm{in} 25^{\circ} \mathrm{C}$. and biological oxygen Jemand measured anter s days manged from t to $10 \mathrm{mR}$ per liter. Water from all wells was acidic, with $\mathrm{pH}$ values mngimp from 4.8 to 6,0. Dissolved oxygen whs present at $2.9 \mathrm{mg}$ ner liter in water from the shallow well (MW11) sereened n! $31018 \cap$. hut it was not detected in the adjacent well (MW]iA) screened at $271032 \mathrm{n}$. Inorgnnic nutrients were mensured in Rroundwater st concentmtions of $3.4 \mathrm{mg}$ of $n \mathrm{mmonia}-\mathrm{N}$ per liter, $0.042 \mathrm{mg}$ of nitmie. $\mathrm{N}$ per liter, and $<1.0 \mathrm{mg}$ of orhophosphote per liter.

The $I 0 t a l$ petroleum hydrocntion concentrations in sedi. menis from borings HA4 and HAS used for these expen. ments mnged from 13 to $\left(152 \mathrm{mR} \mathrm{kg}^{-1}\right.$ (Tahle 2). Sediment from other arens within the contaminant plume contained fulal petrulcum hydrociurlwon cuncentrations ranging from /1 10 $4.487 \mathrm{mg} \mathrm{kg}^{-1}$ (Jry weight), with an average concentmition of $79 \mathrm{mg} \mathrm{kg}$. Cuncenirntions of alkyltenzenes in ground. winter from these areas were as high as $3 \mathrm{mg}$ of benzene mer liter, $5 \mathrm{mg}$ of toluene per liter. I mp of elhylbenzene per liter. and $3 \mathrm{mg}$ of xylene per liter, and values for toln organic catton were as high as $\mathbf{0 0} \mathrm{mR}$ per liter.

Fate of "C-radblabetrd lestopes. The microhes from the North Charteston sediment were nclive despite heavy conInmination with jet fuel. Respirntion was mensured nfier 24 $h$, nnd it renched a maximum after 3 days of incubalion during incuhations with $s \mathrm{ng}$ of $\left({ }^{14} \mathrm{C} / \mathrm{g}\right.$ lucose per p (Fig. 2$)$. Initinl respiration mies calculnted over the first 3 dnys of incritation were on the onder of 2.4\% per ony. and the maximum amount respired was approximately $9 \%$. The udition of $0.1 \mathrm{mM} \mathrm{NO}$, or $0.1 \mathrm{mMN}$ N, did not significnntly incrense respiration mice or the'maximum merceninge of the glucese respired over those of the unamended samples. A mass halance of the distribution of the added $\left.\right|^{10}$ Clelucose surgetled that cellular incomoration of the ${ }^{14} \mathrm{C}$ was not difterent in the nitrogen-nmended and unamended samples when measured afier 1 and 29 days of incuhation (Tahle 1 ). 


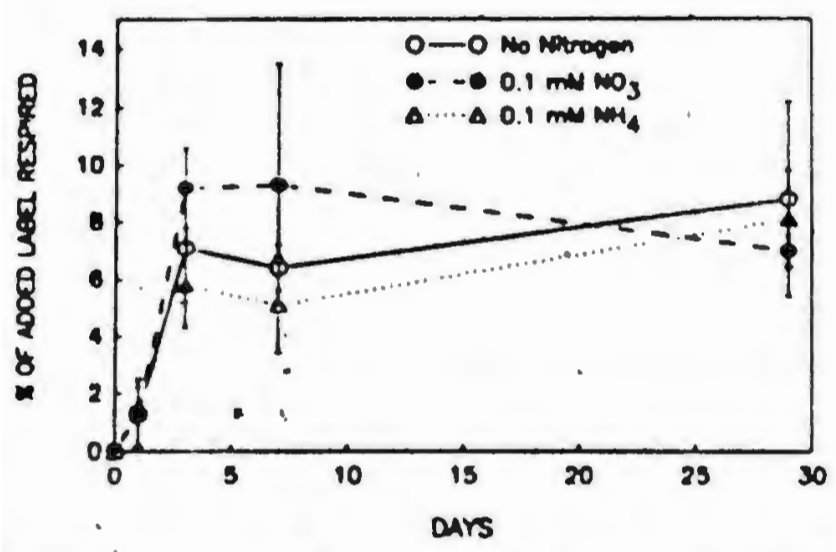

FL. 2. '19'islucose respiration over lime in somples with no added nitropen. and in enmples amended with $0.1 \mathrm{mM} \mathrm{N})_{2}$. nnd in

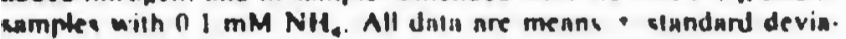
tiin:

When $l^{14}\left(\right.$ iglucose $\left(4 \mathrm{ng} \mathrm{R}^{-1}\right)$ was incubnted with $\mathrm{n}$ higher concentration of nitmte. $1.7 \mathrm{mM}$. A decrense in the mnximum percentnge of glucose respired was measured in the nitmic. amended samples as compared with that of the unamended camples, $8^{r}$ q versus $167^{\circ}$. respectively, after $R$ dnys of. incubation (fig. 3). A mass balance procedure was pertormed aner 2h days of incubntion, nt which noint respimtion was lower in both nitrate-nmended and unamended anmples than that mensured iffer 8 days (Tnhle 3). Although the ${ }^{2} \mathrm{O}$, mensured aner 26 dnys was grenter in the snmple with no nitrite. 6\% versus 4\%, a significnnily stenter perceninge of the Inteled carton added was incommated into cellular matcrinl for the nitrate-umended snmples, $24: 7$ versus 7\%. The totnl glucose metnhulized. ns indicnted hy respimtion nnd cellular incormonution. was approximulely twice ne gredit for'the nitmie-amended enmples (2H\%) ns for the unamended anmples (147).

Results from incuhations with "C-radiolaheled loluene (17 $\left.n g R^{-1}\right)$, henrene $\left(7 n g g^{-1}\right)$, and henzene $\left(7 n R R^{-1}\right)$ nmended with $3 \mathrm{mM}$ NO, showed limited mineralization (less than 0.5\% afier 4 monthe of incubntion) of these communds (dutn

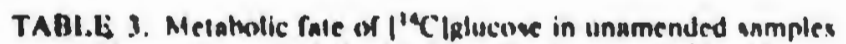
and samples amended with $0.1 \mathrm{mM}$ nilmate and $(1.1 \mathrm{mM}$ adimonium aner 1 ahd 20 days of incubation and in samples famended with $1.7 \mathrm{mM}$ nilrate aner 26 day of incuhation

\begin{tabular}{|c|c|c|c|c|c|}
\hline \multirow[b]{2}{*}{$\begin{array}{l}\text { Sample } \\
\text { ammendment } \\
\text { (mM) }\end{array}$} & \multirow[b]{2}{*}{$\begin{array}{l}\text { IDoye of } \\
\text { incuthetikm }\end{array}$} & \multicolumn{3}{|c|}{ 1'4' lelucme } & 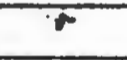 \\
\hline & & $\begin{array}{l}\text { Cinncen } \\
\text { added } \\
\text { Ins a ') }\end{array}$ & Ampiresor & $\stackrel{\gamma}{U_{\text {malke }}}$ & $\stackrel{\gamma}{x}$ \\
\hline $\operatorname{NnN}$ & 1 & 5 & 1 & 5 & M4 \\
\hline $0.1 N()$, & 1 & 5 & 1 & - & KI \\
\hline $0.1 \mathrm{NII}$ & ' 1 & 5 & ! & 3 & 72 \\
\hline No $N$ & 2 & 5 & 7 & 9 & 100 \\
\hline $0.1 \mathrm{NO}$, & 29 & 5 & 7 & 9 & $W$ \\
\hline $0.1 \mathrm{NH}$ & 20 & 5 & 7 & .9 & 100 \\
\hline $\mathrm{Nn} N$ & 26 & 4 & ค & 7 & 77 \\
\hline $1.7 \mathrm{NO}$, & 26 & 4 & 4 & 24 & B! \\
\hline
\end{tabular}

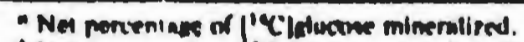

- Net percens ace of le lahet recovered im hilen.

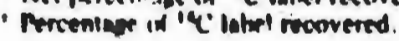

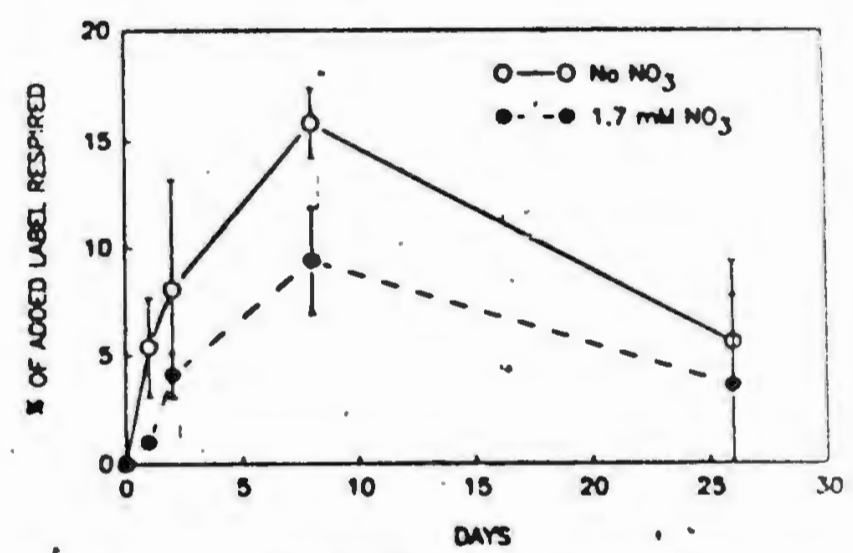

FiG. 1. l'Cleluense respiralion over time in snmples with nil ndade N(), and in somples amemded with $1.7 \mathrm{mM} \mathrm{NO}$. All dilla are means: anndand deviations.

not shown). There was no significant difference in $14(9)$, cvolution in experimental nnd contrul vinls for any whe conditions. Becnuse hs? of the sodded toluene reminined dissolved in the fihmie nfter 3 months of incutation. if is unlikely that volntilization of toluene limited the respir:1l1.:1 of this compound during the experiment. At threc 10 to 111 limes higher concentrations of henzene $130 \mathrm{ng} R$ ') insl lolitene (4.3 $\mathrm{ng} \mathrm{g}^{-1}$ ). boih inmended with $1.2 \mathrm{mM} \mathrm{N}(1,$. respimtion why ngnin low and less than 0.57 of the radlulisheled carton u'ns mensured ns ${ }^{14} \mathrm{CO}_{2}$ (Fir. 4). Hukeser. it distinction in minemlization hetween experimental und conn. trol vials whs ohserved. Approximntely three times ns man! disintegrations per minute were mensured from ${ }^{14} \mathrm{C}()$, pro(Huction in live unmples than that from metabolically inhil. ited control vinls. This difference in ${ }^{14} \mathrm{CO}$; production was mensured nfler upprtiximntely 7.dnys and remuined constiml for the remnining 3 months of incubation.

Gas chromatoxpaphe expertmenth. Gus chromntographlic annlyses of vial hendspuce genses indicnted high rates al ("), production in $1 \mathrm{mM}$ nitmie-nmended sediment snmples Ilip 5). $\mathrm{CO}$, was mensured anter 4 dnys of iricuhation and incrensed linenrly throughout 2 months of incubation $11^{\circ}$.. (1.902). CO, production may have hegun to decresise 1110 (1) 70 days of incuhation. $\mathrm{CO}$, production mes for these samples

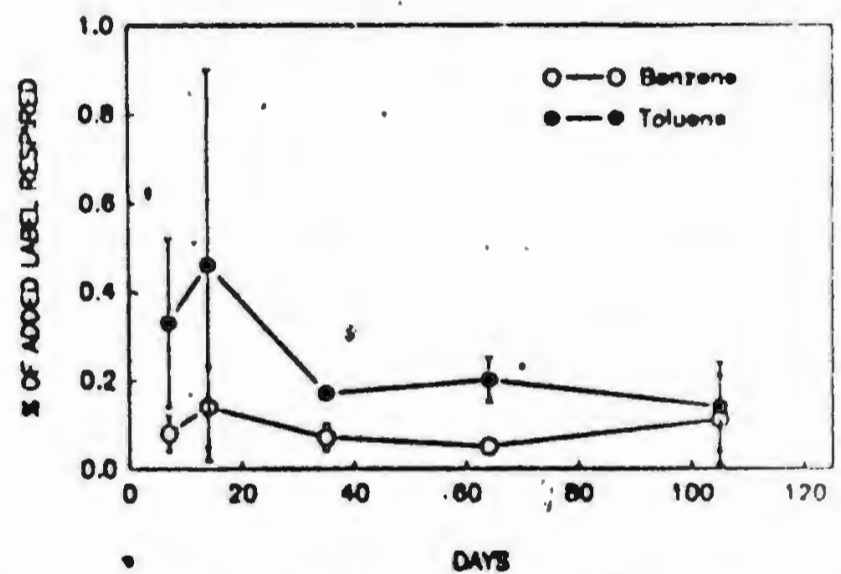

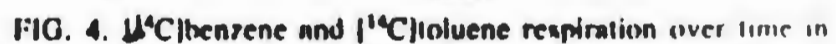
anmples amended with $1.2 \mathrm{mM}$ nitrate. All data are menrs. alandard deviations. 
Vo1. $57,1 \% !$

MICROBIAL ACTIVITY IN JET FUEL-CONTAMINATED AQUIFER

17

tuluene and benzene hy mixed methanemenic cultures. Appl. linvirun Micmbiol. \$3:2:4-2(t).

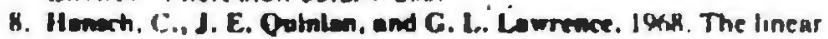
free energy relalionship belween partilion coefliciems and the squerous solubility of organic liquids. 1. Org. Chem. 13:147-3.6.

9. Jefvert, C.T., and N. L. Winte. IWW7. Degrodation of relected halogen.iled ethanes in anoxic sediment-woter iystems. Envirun. Toricol. Chem. 6:127-H37.

10. Kuhn, 1. P., J. Zeyer, P. Fictur, and R. P. Schwarembect, 19kh. Ariatotic degradalion of alkylaled henzenes in denilrify. ing taturuton' aquifer columns. Amp. Environ. Microtiol. S4:

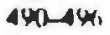

11. I, A. A. T. tand D. K. Rutton. 19R. Mexdulation of affinity of a marine : seudomonad for loluene and henzene hy hydmcartion expoulle. Appl. Environ. Microbiol. S1:4te-476.

12. IAF, M. D.. J. M. Thronas, R. C. Banden, P. B. Rndwen!, J. T. Willean, and C. H. Wand. 19RR. Bioresturatuon of nquifer comtaminuled with oreanic compounds. CRC Crit. Res. Iinvi. mon. Control in:rustr.

13. Mackis, D., and W. V. Shlu. 19k1. A critical revied of llenry's Law Comblants for chemicalo of envirunmental interes. J. Ithys. Chem. Vef. 1)ata 10:1179-11W.

14. MaJor, W, M., C. I. Maytheld, and J. F. Rarker. IGkK. Hirurans. formalion of hertene by denitrification in aquifer sand. Ciround Whater 2a:k-14.

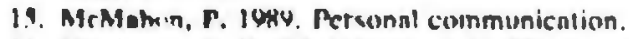

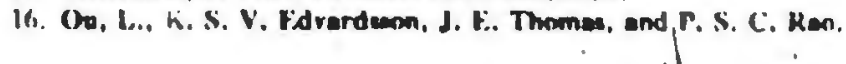

1445. Aernhic und anaerobic degradation of aldicart in wils Apric. Fond Chem. 1.:\$4:-544.

17. Raymond, R. I., V., W. Jamkenn, J. O. Hedean, R. F. MAhrturll, and V. F. Former. 197R. Final teport. Field anplication of aubsurface hindegradation of gawoline in a sand formaluon Project no. 307.77. American Petroleum Institute, Washingtion. D.C.

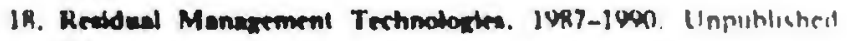
duta.

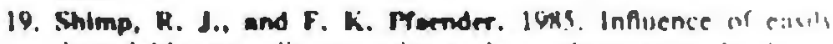
degradahle naturally oscuming eartion suhstrates on hisurer:a dation of monowubslituled phenols hy nquatic baclena Arri Iinvirun. Micrutiol. 49:190-401.

20. Swindoll, C. M., C. M. Aelion, D. C. Dathtins, O. Jieng. S. C. lare. and F. K. Mander. IGRK. Aerntic biculegnidia! ion "." natural and xenchiotic orkanic comnounds by suhsurface micrs: hial communities. linvim. Toxicol. Chem. 7:2W1-2W

21. Sirindall, C. M.. C. M. Aation. and F. K. Morender, luysi

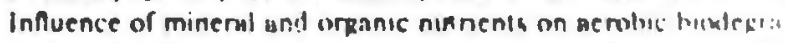

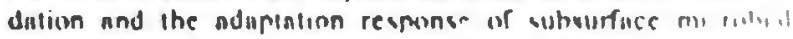
communities. Arpl I:nvirun. M1sruhiol. S4:212-217

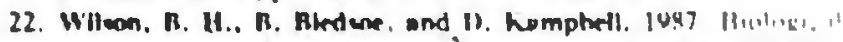

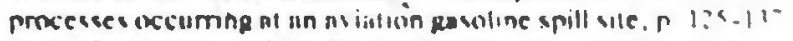
In R. C. Averelt and I). M. Mekinight ied.). Quslus of wille

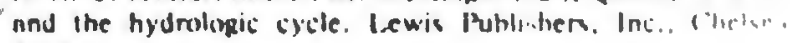
Mich. 


\title{
- Bioremediation Potential of Terrestrial Fuel Spills $\dagger$
}

\author{
HONG-GYU SONG, $¥$ XIAOPING WANG, AND RICHARD BARTHA*-

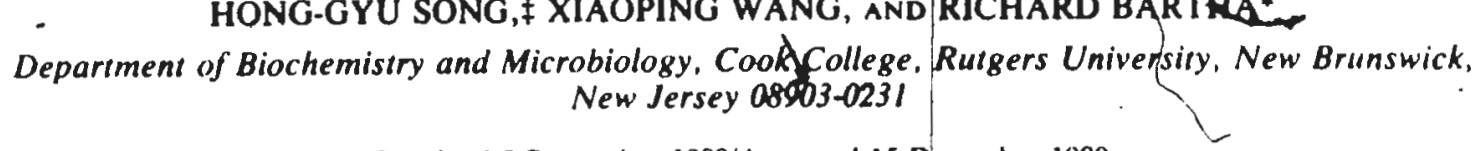

Received 5 Seplember 1989/Accepled 15 Decumber 1989

\begin{abstract}
A bloremediation treatment that consisted of lining, fertilization, and tilling was evaluated on the laboratory s. ale for its efiectiveness in cleaning up a sand, a loum, and a, clay loapen contaminated at 50 to $135 \mathrm{mg}^{8}$ of coll ${ }^{-1}$ by gasoline, jet fuel, beating oll, dlesel oll, or bunker C. Experimental variables included Incubation te mperatures of 17, 27, and $37^{\circ} \mathrm{C}$; mo treatment; bloremediation treatment; and poisoned evaporation controus: H ydrocarbon residues were determined by quantitatlve gas chromitography or, in the case of bunker C, by risidual weight determination. Four-polnt depletion curves were obtuined for the described expertmenth vartabtes. In all cases, the dapppearance of hydrocarbons wa madiand at $27^{\circ} \mathrm{C}$ and in responoe to bioremediation trentment. Polsoned evaporation controls underestmated the true blodegradation contribution, but nevertheless, they showed that blodegradation makes only a modeat contribution to gasoline disappearance from soll. Bunker $\mathrm{C}$ was found to be structurally recalctirant, with ckose to 80\% persisting after 1 year of incubation. The three medium distillates, jet fuel, heating oll, and diead oll, increaved in persiatence In the listed order but responded well to bloremediation treatment inder all teat conditions. With bloremedf. a ion treatment, it should be posslble to reduce hydrocarbons to insignificant levels in contaminated colbs within one growing season.
\end{abstract}

Soil that is accidentally contaminated by petroleum fuel spills is classified as hazardous waste (2). When the amounts of contagninated soil are large, the currently accepted disposal metiods of incineration or burial in secure chemical landfills can become prohibitively expensive. This often results in cleamup delays while the contaminated soil continues to pollute scance groundwater resources (8). Land treatment disposal of ofly refinery sludges has been practiced for decades with genterally good results (1). This project was designed to test, on the laboratory scale, what type of fuel spills could be cleaned up by a cost-effective bioremediation approach hased on a land treatment process optimized for oily sludg:s (4). In addition to five different fuels, the variables included three contamination levels, three incubation temperatures, and three different soil types. Petroleum hydrocarbon disappearance rates were compared in contaminated but otherwise untreated soil, in bioremediationtreated so:l, and in soil poisoned in order to suppress biodegrad: tion (6).

\section{MATERIALS AND METHODS}

Fuel praducts. The following fuel products were selected for use in this study: as a low-boiling-point distillate, unleaded gasoline; as a medium-boiling-point distillates, jet fuel, heati ig cil (no. 2 fuel oil), and diesel oil; and as a high-boiling-point distillate, bunker $C$ (residual fuel oil). The bunker C sample contained 15 to $20 \%$ (by volume) of a medium dissillate, which is commonly auded to lower the otherwise very high pour point of this product. All products were supplied by the Bayway Refinery, N.J. (Exxon USA). The fuel products were initially characterized as to their ciass comrosition and carbon range.

Preparaition and incubation of fuet-contaminatid soll sam.

\footnotetext{
- Corresponding author.

$\uparrow$ New Jersey Agricultural Experimert Station Publication no. D-01502-0.3..85.

t Prescal oddress: Departrnent of Microbiology, Ulsan University, Nam-Ku, Mugeo-Dong. Ulsan, South Korea.
}

ples. Soils were selected to include light, medium, and heavy textured ones. Their textures, organic matter contents, and pHs were determined (7). Soils were freshly collected for each experiment. They were partially but not completely air dried to allow sleving (2-mm-diameter openings) for uniform consistendy, but without damaging their biological activity. The sieved soils were packed into glass columns (outer diameter, $25 \mathrm{~mm}$; length, $250 \mathrm{~mm}$ ) at the bulk density of cores collected from the field. The resulting columns were 60 8 (dry welght), $22 \mathrm{~mm}$ in diameter, and $150 \mathrm{~mm}$ in length. The lower ends of the columns were closed with a Teflon (E. I. du Pont de Nemours \& Co., Inc., Wilmington, Del.)wrapped plug and a closable drain spout. After packing, water was added to the top of the column to adjust the moisture content of the soil to $50 \%$ of its holding capacity. Lime $\left(\mathrm{CaCO}_{3}\right)$ was added to semidry soil prior to column packing. The amount was based on liming curves, and the lowest amount of $\mathrm{CaCO}_{3}$ sufficient to raise the $\mathrm{pH}$ to 7.5 to 7.6 (7) was added. For all three soils, this was $10 \mathrm{mg}$ of $\mathrm{CaCO}_{3} \mathrm{~B}$ of soil ${ }^{-1}$.

Nitrogen and phosphorus fertilizers, unless noted otherwise, were $60 \mu \mathrm{mol}$ of $\mathrm{N}$ as $\mathrm{NH}_{4} \mathrm{NO}_{3}$ and $S \mu \mathrm{mol}$ of $\mathrm{P}$ as $\mathrm{K}_{2} \mathrm{HPO}_{4} 8$ of $80 \mathrm{il}^{-1}$ (4). They were dissolved in the water that was used for adjusting the moisture content. Soli columns were contaminated with fuel products by placing the fuel products on top of the colımns and allowing them to infiltrate by gravity flow. The maximal applicntion rate (135 $\mathrm{mg} \mathrm{g}$ of soil-1) was chosen so that it would not result in either fuel or water flowing out from the soil column. Bunker $C$ was too viscous to be applied in this manner. It was mixed with semidry soil and was packed and subsequently moistened. The evaporation of water during incubation was compensnted for by weighing the prepared suil columris and adding distilled water to compensate for any weight loss during incubation. Weekly tilling of the soil columns was performed by insering a stainfess steel wire inte the soil columns 15 times. This ircatment, which was forced oy llie constrains s of the incubation system, was much ie: s ettectiv.. in aerating the soll than conveational rilling in the fielc is 
Biologically inactive poisoned controls $\left(2 \% \mathrm{HgCl}_{2}\right)$ were used to differentiate evaporative losses from biodegradative losses (6). The poisoned controls showed the maximal evaporative loss that may occur under the incubation conditions. In fact, however, biodegradation and evaporation compete in the removal of petroleum hydrocarbon, and subtracting the loss of hydrocarbons from poisoned controls from the loss observed in active soil samples strongly underestimates the true contribution of biodegradation. This fact should be kept in mind when interpreting the results.

Analytical methods. For each point of analysis, the fuel in the soil of an entire column, was extracted. Gasoline was extracted from soil with cold Freon 11 (fluorotrichloromethane; E. I. du Pont de Nemours \& Co., Inc.). Anhydrous sodium sulfate (equal in weight to the weight of the soil) and i $50 \mathrm{ml}$ of Freon 11 were sealed with the soil into a $500 \mathrm{ml}$ Teflon-lined screw-cap flask and shaken at $17^{\circ} \mathrm{C}$ at 200 rpm for $24 \mathrm{~h}$. The sample was filtered in a cold room, the soil residue wat washed, and the total Freon 11 extract was brought to volume. Bromooctane was used as the internal standand.

Jet fuel, hoating oil, diesel oil, and bunker $\mathbf{C}$ were Soxhlet extracted for $6 \mathrm{~h}$ by using methylene chloride. Anhydrous sodium sulfate, was added to the extraction thimble to absorb sample moisture. After the extraction of bunker $\mathrm{C}$, which has no highly volatile components, the solvent was evaporated in a preweighed dish and the residual weight was determined gravimetrically. Extracts of the medium distillates were brought to volume, internal standards (octadecane for jet fuel; tetracosane, for heating oil and diesel oil) were added, and the extracts were analyzed by gas chromatography by using an instrument (Model \$890; HewlettPackand Co., Palo Alto, Calif.) with a 10-m macrobore (0.53-mm diameter) fused-silica capillary column with an immobilized polydimethyl siloxane phase (Alttech Associates, Inc., Deerfield, III.). The nitrogen carrier flow rate was $30 \mathrm{ml} \mathrm{min}-1$; hydrogen and air for the fiame ionization detector had flow rates of 40 and $200 \mathrm{ml} \mathrm{min}^{-1}$, respectively. Temperatures for gasoline analysis were as follows: injection port, $150^{\circ} \mathrm{C}$; flame ionization detector, $250^{\circ} \mathrm{C}$; oven, initially $35^{\circ} \mathrm{C}$ and programmed to reach $150^{\circ} \mathrm{C}$ at $4^{\circ} \mathrm{C} \mathrm{min}^{-1}$. For jet fuel, the initial oven temperature was $50^{\circ} \mathrm{C}$ and was programmed to reach $200^{\circ} \mathrm{C}$ at $4^{\circ} \mathrm{C} \mathrm{min}^{-1}$. For heating oil and diesel oil. the initial oven temperature was $50^{\circ} \mathrm{C}$ and was programmed to reach $205^{\circ} \mathrm{C}$ at $4^{\circ} \mathrm{C} \mathrm{min}-1$. Dilutions of the original products in $\mathrm{CH}_{2} \mathrm{Cl}_{2}$ served as quantitative analytical standands. All fuel residues were expressed as milligrams of hydrocar: on gram of dry soil ${ }^{-1}$.

For cla is separation, each fuel sample except gasoline was fractionared on a silica gel column. The silica gel (Aldrich Chemical Co., Inc., Milwaukee, Wis.) was activated at $105^{\circ} \mathrm{C}$ fol $12 \mathrm{~h}$. The glass column $(2$ by $28 \mathrm{~cm}$ ) was packed with silic I gel suspended in hexane. The 0.5-g hydrocarbon samples ivere adsorbed on $\mathbf{3} \mathbf{g}$ of silica gel and placed on the column. A 3-g layer of anhydrous sodium sulfate was placed over the sample to absorb any water and to prevent the disturbance of the sample with the solvents. The class fractionaitons of petroleum products were accomplished by successive elution in a discontinuous solvent gradient of increasing polarity. The saturated, aromatic, and asphaltic classes v'ere eluted with $120 \mathrm{ml}$ of hexane, benzene, and chlorofor m-methanol $(1: 1 ; \mathrm{vol} / \mathrm{vol})$, respectively.

\section{RESULTS AND DISCUSSION}

Charactertstics of the fucts and solts. Some characteristics of the five fuels used in this study are summarized in Table
TABLE 1. Analysis of the fuel products used in the spill bioremediation study

\begin{tabular}{|c|c|c|c|c|}
\hline \multirow{2}{*}{ Fuel product } & \multicolumn{4}{|c|}{ Class composition $(\%)^{e}$} \\
\hline & Saturates $^{b}$ & Aromatics ${ }^{\circ}$ & Polard & "Carbon ranee?" \\
\hline Gasoline & & Not analyzed & 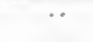 & $i$ \\
\hline Jet fuel. & 83.0 & 15.7 & 1.3 & \\
\hline Heating oil & 62.5 & 32.9 & 1.9 & \\
\hline Diesel oil & 53.7 & 45.0 & 1.3 & $C_{0}-C_{23}$ \\
\hline Bunker C & 52.6 & 35.0 & 12.4 & Not analyzed? \\
\hline
\end{tabular}

- Chromatographic separations done on a silica gel columa.

- Hexane cluate.

- Benzene eluase.

"Chlorolorm-methanol (1:1; volvol) eluate.

- Based on gas chromatographic analysis and comparison with authentic $n$-alkane standands.

$f$ According fo a distillation curve, the bunker $C$ sample contained $151020 \%$ of a medium distillate (probably heating oil) added to lower the pourinit pouth of the product.

1. With the exception of bunker C, all products had very. low levels of polar compounds. From the three medium disti lates, jet fuel had the lowest and diesel fuel had the highest levels of aromatic compounds, with heating oil having ther mediate levels. The reciprocal was true for saturated compounds. Diesel oil had the widest carbon number range The values found in this study showed a good correlation. with published product specifications (5). As saturated conpounds are generally more easily, biodegraded than the corresponding aromatic compounds are $(1,3)$, the compositional data also helped to interpret some of our biodenradat tion results.

The textural compositions, organic matter contents, and initial pHs of the three types of soils used in these experi ments are summarize in Table 2. Lakewood sand was particularly low-quality soil with a very acidic $\mathrm{pH}$. A heavy clay soil was not available in the study area, and the selected Penn clay loam was only slightly more heavily texturedithan the loam soil was.

The analytical approaches for the five fuel products, their mean time zero recoveries, and the standard deviations of these recoveries are summarized in Table 3 . As the number of determinations prevented the use of replicate samples in routine analyses, the standard deviations in Table 3 give some $g$ theral confidence limits for the analytical procedures that wer used in terms of recovery and repeatability.

Kinetles of fuel disappearance and data presentation. Our studies generated a four-point depletion curve for each fuel type under a wide variety of incubation conditions (temper: atures, soil types, loading rates, bioremediation treatments, poisoned controls). The volume of the data precluded the presentation of all these curves, yet their mathematical

TABLE 2. Characterjstics of the three soil types used in the biodegradation experiments

\begin{tabular}{lcrrrrr}
\hline \multirow{2}{*}{ Soil type } & \multicolumn{3}{c}{ Texture (\%) } & & \multicolumn{1}{c}{$\begin{array}{c}\text { Organic } \\
\text { matter (\%) }\end{array}$} & pH \\
\cline { 2 - 5 } & Sand & \multicolumn{1}{c}{ Silt } & Clay & & & \\
\hline Loam, Baywaya & 36 & 40 & 24 & 2.7 & 4.3 \\
Lakewood sand $^{b}$ & 90 & 4 & 6 & 4.9 & 4.0 \\
Penn clay loam & 9 & 44 & 34 & 22 & 1.3 & 4.9 \\
\hline
\end{tabular}

-Fron: the grounds of the Bayway Refinery (Exxon USA). There was no previous spill exposurt.

- Pine Barrens, N.J., pine-oak forest; state park.

r Piscalaway, N.J., meadow: recieational use. 
TABLE 3. Extraction, analysis, and time zero recovery from soil of the five fuels used in this study

\begin{tabular}{llcr}
\hline \multicolumn{1}{c}{ Product } & Extraction & Analysis & $\begin{array}{c}\text { Mean } \pm \mathrm{SD} \\
\text { recovery }(\%)^{4}\end{array}$ \\
\hline Gasoline & -Cold Freon 11 & $\mathrm{GC}^{b}$ & $93.7 \pm 1.9$ \\
Jet fuel" & Soxhlet, $\mathrm{CH}_{2} \mathrm{Cl}_{2}$ & $\mathrm{GC}$ & $98.5 \pm 2.7$ \\
Heating oil & Soxhlet, $\mathrm{CH}_{2} \mathrm{Cl}_{2}$ & $\mathrm{GC}$ & $98.0 \pm 1.4$ \\
Diesel oil & Soxhlet, $\mathrm{CH}_{2} \mathrm{Cl}_{2}$ & $\mathrm{GC}$ & $97.3 \pm 2.3$ \\
Bunker C & Soxhlet, $\mathrm{CH}_{2} \mathrm{Cl}_{2}$ & Residual wt & $99.5 \pm 1.5$ \\
\hline
\end{tabular}

- Based on triplicate samples at the low (50-mg g of soil-1) loading rate.

- GC. Gas chromatography.

reduction to constants was made problematic by the complex nature of the fuels and by the soil incubation system.

The classical pattern of material depletion by a constant force shows first-order (exponential) kinetics. Because of diffusion limitations and increases in the degrading microbial populations, even the depletion of a homogeneous substrate in soil is rarely first order but, rather, is intermediate between first-order (exponential) and zero-order (linear) kinetics. The kinetics are further complicated in the case of fuels by the fact that these consist of numerous individual hydrocarbons, each of which is utilized at a different rate. The slowing tendency of utilization is caused not only by substrate depletion but also by the fact that the remaining hydrocarbons are structurally less degradable than are the ones that already disappeared $(1,3)$. To some extent, this is compensated for by the increasing numbers (enrichment) of the hydrocarbon-degrading microorganisms in the soil with time. For the reasons described above, there is no precise way to convert the curves obtained in this study to constants. For the purpo'ses of the data in Table 4, half-life is simply the time needed to reduce the total fuel concentration in soil to $50 \%$ of the initial amount. If a $50 \%$ reduction was not achieved within the time period of the experiment, Table 4 simply indicates this fact (e.g., half-life, $>12$ weeks). The half-lives used in Table 4 in their restricted sense still give a useful comparison of the relative biodegradability of the five fuels and of the environmental conditions that favor or restrict the process. In addition to Table 4, we included one set of depletion curves (see Fig. 1 through 5 ) for each fuel type in order to illustrate their typical kinetics of disappear. ance.

Concerning the data in Table 4, some generalizations apply to all fuel products. Half-lives of fuels were longest in poisoned soils, and only the highly volatile gasoline reached a $50 \%$ depletion in such soils. Half-lives of fuels were also longer in untreated thain in: treated soils and longer at $17^{\circ} \mathrm{C}$ than at $27^{\circ} \mathrm{C}$. A further increase in temperature to $37^{\circ} \mathrm{C}$ increased rather than shortened the fuel half-lives. This was also observed in a previous study (4) with oil sludges and probably reflects the increased attack of hydrocarbons on microbial membranes at elevated temperatures. Increased fuel concertrations tended to increase half-lives only moderately. As to the effect of soil types, half-lives tended to be longest in the sand, a soil with poor absorbing capacity and low microbial diversity. Half-lives in clay loam were slightly shorter than those in loam.

Unleaded gasoline. Th disappearance kinetics (Fig. 1) and half-lives (Table 4) of thleaded gasoline differed only very slightly in untreated, treated, and poisoned soils. Compared with the medium distillates, biodegradation played a smaller relative role in the overall removal of gasoline hydrocarbons from soil. The $C_{6}$ to $C_{9}$ components of gasoline (Table 1 ), under the conditions of hese experiments, were lost more
TABLE 4. Half-lives of five fuels in three soil types under various incubation conditions

\begin{tabular}{|c|c|c|c|c|c|}
\hline \multirow{2}{*}{\multicolumn{2}{|c|}{$\begin{array}{l}\text { Ayels, soil type. a } \\
\text { Hncubation temp } \\
\left({ }^{\circ} \mathrm{C}\right)^{\circ}\end{array}$}} & \multirow{2}{*}{$\begin{array}{l}\text { Fuel added } \\
\text { (mg g [dry wr] } \\
\text { of soil }^{-1} \text { ) }\end{array}$} & \multicolumn{3}{|c|}{ Half-life $^{b}$} \\
\hline & & & Untreated $^{c}$ & Treated $^{d}$ & Poisoned" \\
\hline \multicolumn{6}{|c|}{ Unleaded gasoline } \\
\hline \multicolumn{6}{|c|}{ Sand } \\
\hline 27 & & 50 & 2.1 & 1.5 & 2.3 \\
\hline \multicolumn{6}{|l|}{ Loam } \\
\hline 27 & & 50 & 1.7 & 1.5 & 2.0 \\
\hline 37 & & so & 1.2 & ND & 1.8 \\
\hline 27 & & 100 & 1.7 & 1.5 & 2.0 \\
\hline 27 & & 135 & 1.7 & 1.5 & 2.0 \\
\hline \multicolumn{6}{|l|}{ Clay } \\
\hline 27 & & 50 & 2.7 & 2.3 & 4.5 \\
\hline \multicolumn{6}{|l|}{ Jet fuel } \\
\hline $\begin{array}{c}\text { Sand } \\
27\end{array}$ & & 50 & $>12.0$ & 6.0 & $>12.0$ \\
\hline \multicolumn{6}{|l|}{ Loam } \\
\hline 17 & & 50 & $>12.0$ & ND & $>12.0$ \\
\hline 27 & & 50 & $>12.0$ & 4.4 & $>12.0$ \\
\hline 37 & $!$ & 50 & $>12.0$ & 6.0 & $>12.0$ \\
\hline 27 & & 100 & ND & ND & $>12.0$ \\
\hline 27 & & 135 & $>12.0$ & 7.5 & 8.0 \\
\hline \multicolumn{6}{|l|}{ Clay } \\
\hline 27 & & 50 & 3.5 & 1.7 & $>18.0$ \\
\hline \multicolumn{6}{|l|}{ Heating oil } \\
\hline 27 & 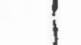 & 50 & $>18.0$ & $>18.0$ & $>18.0$ \\
\hline 'Loam & & & & & \\
\hline 17 & & so & $>18.0$ & 18.0 & $>18.0$ \\
\hline 27 & & 50 & 12.0 & 5.5 & $>18.0$ \\
\hline 37 & & 50 & 12.0 & 6.6 & $>18.0$ \\
\hline 27 & & 100 & $>18.0$ & 9.2 & $>18.0$ \\
\hline 27 & & 135 & $>18.0$ & 12.5 & $>18.0$ \\
\hline \multicolumn{6}{|l|}{ Clay } \\
\hline 27 & & 30 & 9.0 & 5.5 & $>18.0$ \\
\hline \multicolumn{6}{|l|}{$\begin{array}{l}\text { Diesel oil } \\
\text { Loam }\end{array}$} \\
\hline 27 & & so & $>18.0^{\circ}$ & $7.0^{h}$ & $>18.0$ \\
\hline 27 & & 100 & $>18.0^{\circ}$ & $7.0^{h}$ & $>48.0$ \\
\hline \multicolumn{6}{|l|}{$\begin{array}{c}\text { Bunker C } \\
\text { Sand }\end{array}$} \\
\hline 27. & & 50 & $>48.0$ & $>48.0$ & $>48.0$ \\
\hline \multicolumn{6}{|l|}{ Loam } \\
\hline 17 & & 50 & $>48.0$ & $>48.0$ & $>48.0$ \\
\hline 27 & & 50 & $>48.0$ & $>48.0$ & $>48.0$ \\
\hline 37 & & 50 & $>48.0$ & $>48.0$ & $>48.0$ \\
\hline 27 & & 100 & $>48.0$ & $>48.0$ & $>48.0$ \\
\hline 27 & & 135 & $>48.0$ & $>48.0$ & $>48.0$ \\
\hline \multicolumn{6}{|l|}{ Clay } \\
\hline 27 & 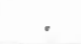 & 50 & $>48.0$ & $>48.0$ & $>48.0$ \\
\hline
\end{tabular}

a Analytidal data on the fuels are summarized in Table 1, and analytical dara on the soils are summurized in Table 2.

- Half-lives are in days for unleaded gasoline and are in weets for all other fuels.

- Untreated describes samples that received the petroleum product only.

- Treated soil samples were treated with lime to an approximate pH of 7.5. received. $\mathbf{N}$ and $\mathbf{P}$ fertilizer, and were tilled weekly.

- Poisoned $\left(2 \% \mathrm{HgCl}_{2}\right.$ ) samples served as ev sporation controls.

ND, Not determined.

- When tilled only (no lime and fertilizer), half-lives decreased at $50 \mathrm{mg} \mathrm{g}$ of soil-1 to 10 weeks and at $100 \mathrm{mg} 8$ of soil $^{-1}$ to 11.3 weeks.

${ }^{h}$ In this case the treated samples received either the normal $(60 \mu \mathrm{mol}$ of $\mathrm{N}$ and $5 \mu \mathrm{mol}$ of $\mathrm{P} \&$ of soil ${ }^{-1}$ ) or only $25 \%$ of this amount. The effects of fertilizer levels on half-lives were manginal and ware averaged.

rapidly by evaporation than by biodegradation, while biodegradation primarily removed the $C_{10}$ to $C_{11}$ components. This became clear when the gas chromatograms from untreated and treated soil samples were compared (data not 


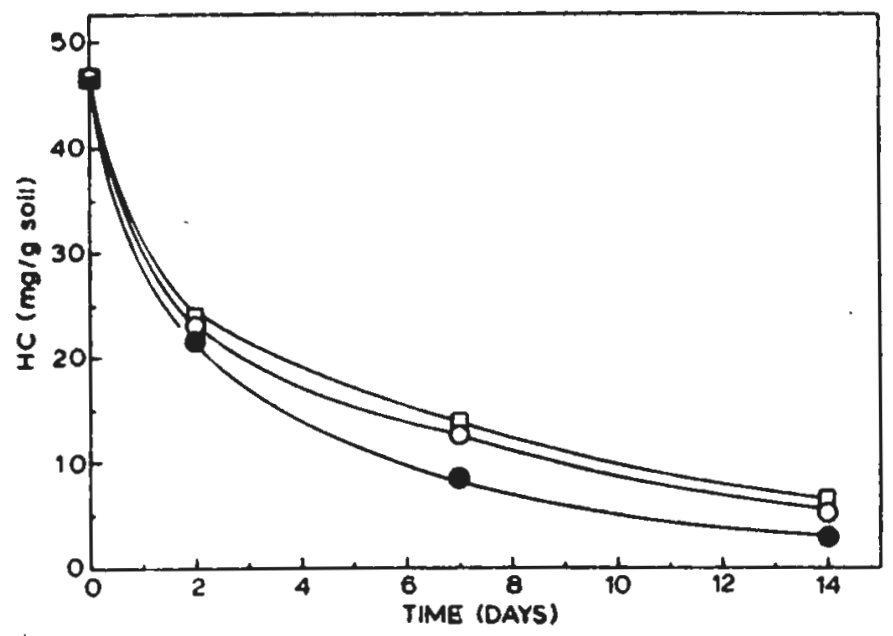

FIG. 1. Disappearance of gasoline hydrocarbon (HC; $50 \mathrm{mg} \mathrm{g}$ of soil $^{-1}$ ) from columns of loam soil. Symbols: $O$, untreated soil; $O$, bioremediation-treated soil; $\square$, poisoned soil.

shown). There was little or no difference in the loss of short-retention-time materials, but treatment that promoted biodegradation visibly increased the loss of the components with longer retention times.

Bunker The disappearance of bunker $\mathrm{C}$ from soil was very slow and incomplete (Fig. 2). None of the samples reached a $50 \%$ reduction during 48 weeks of incubation (Table 4). Bioremediation initially accelerated bunker C disappearance, but no further stimulation was evident after 8 weeks of incubation. We interpret these results as signifying that most bunker $\mathbf{C}$ components were structurally resistant to biodegradation. The maximal weight losses from bunker $\mathrm{C}$ matched closely the amount of medium distillate used to lower the pour point of this product (Table 1). We conclude that bioremediation has only very limited beneficial effects on gasoline and on bunker C elimination from soil, although for quite different reasons.

Jet tuel. Jet fuel disappeared from soil quite rapidly (Fig. 3 and Table 4). As evident from the poisoned samples, volatility losses of jet fuel were potentially quite high; but for the reasons discussed earlier, volatility losses from biologically active samples were actually much lower than those indicated by the poisoned controls. Bioremediation substantially

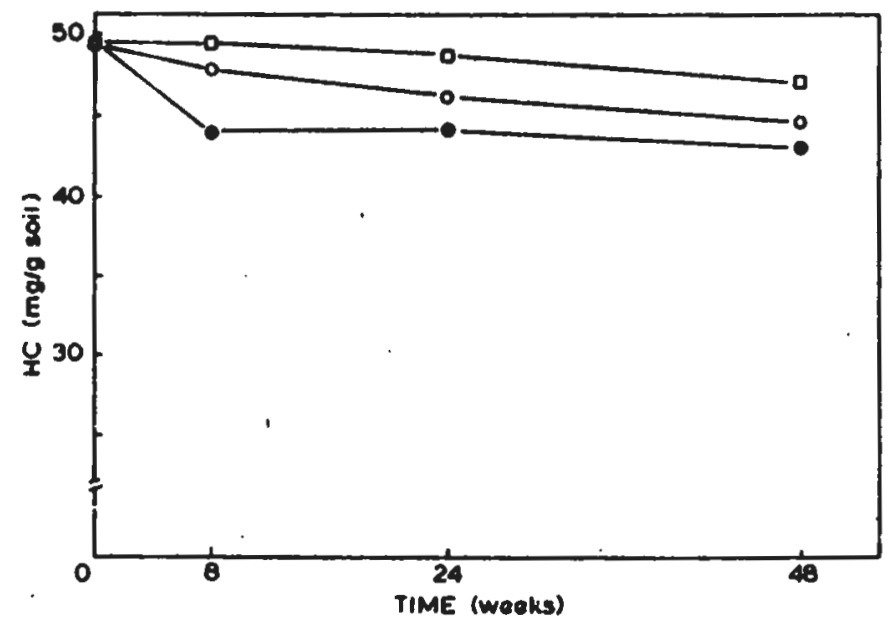

FIG. 2. Disappearance of bunker C hydrocarbon (HC; $50 \mathrm{mg} g$ of soil $^{-1}$ ) from columns of Lakewood sand. Symbols: $O$, untreated sand; $O$, bioremediation-treated sand; $\square$, poisoned sand.

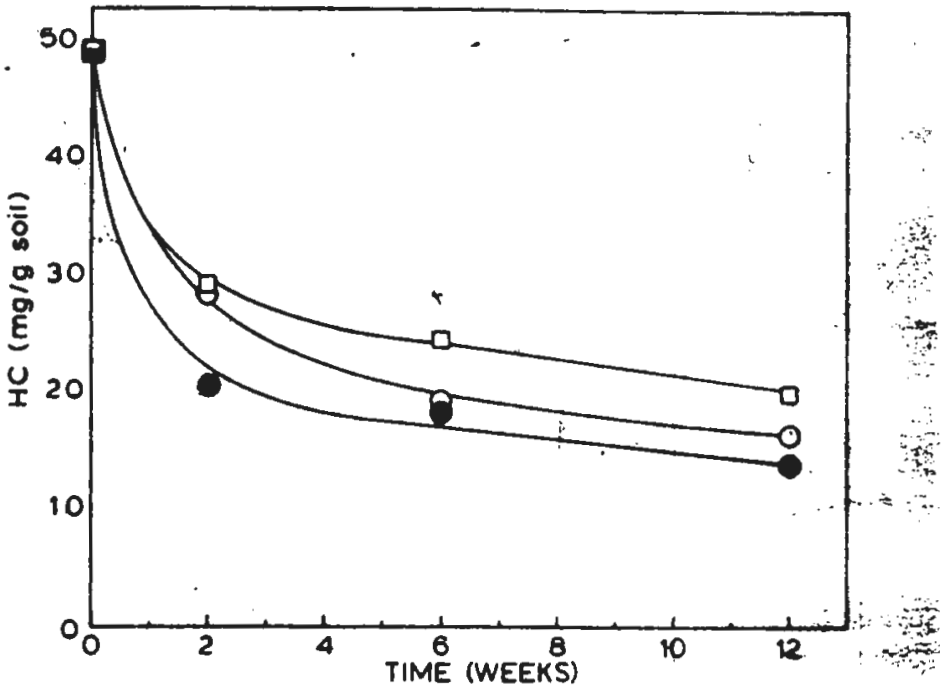

FIG. 3. Disappearance of jet fuel hydrocarbon (HC; $50 \mathrm{mg} g$ of soil ${ }^{-1}$ ) from columns of Penn clay loam. Symbols: $O$, untreated loam; O. bioremediation-treated loam; $\square$, poisoned loam.

accelerated jet fuel disappearance in the first weeks after the spill. In untreated but biologically active soil samples, disappearance tended to catch up to that in the bioremedtutiontreated samples in the later phases of incubation. Although the redox potential profile of the soil columns was not measured, from experiments conducted in thin surface soil layers (9), we concluded that this is largely due to oxygen limitation in the soil columns. The oxygen limitation did not allow bioremediation to manifest its full beneficial effect in this incubation system. In poisoned controls, volatilization failed to reduce jet fel concentrations to $50 \%$ in 12 weeks, except in one case (Clay loam) that we consider to, be an experimental artifact. We believe that the clay loam, with its considerable cation exchange capacity, immobilized most of the $\mathrm{Hg}^{2+}$ ions from the solution in the upper portions of the soil columns and so allowed some biodegradation to occur in the lower portions of the columns.

Heating oll. Heating oil was less volatile and more persistent than jet fuel was (Fig. 4 and Table 4). Heating oil in soil responded well to bioremediation treatment that typically shortened its half-life to $50 \%$ or less as compared with that of untreated soil.

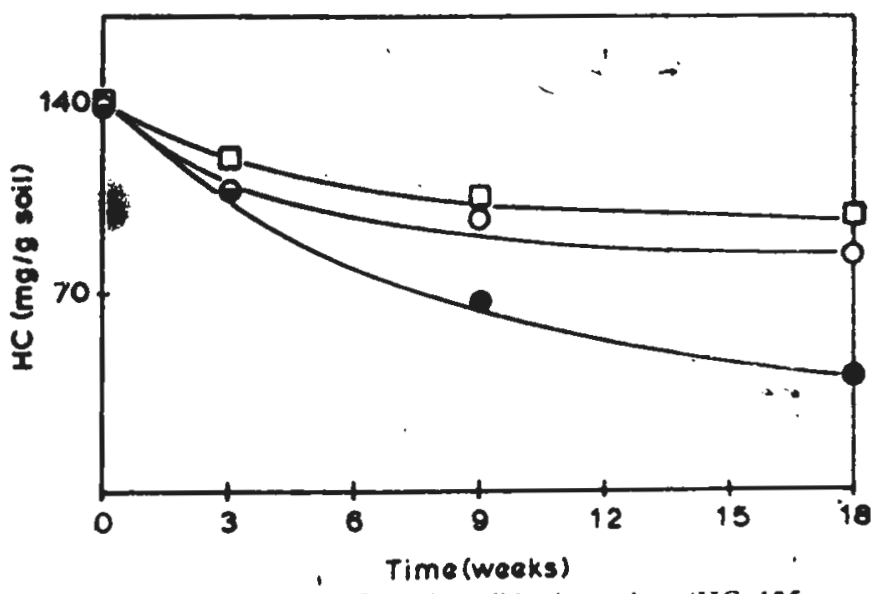

FIG. 4. Disappearance of beating oil hydrocarton (HC; $135 \mathrm{~ms} B$ of soil $^{-1}$ ) from columns of loam soil. Symbols: $O$, untreated loam soil; . bioremediation-treated loam soil; $\square$, poisoned loam soil. 


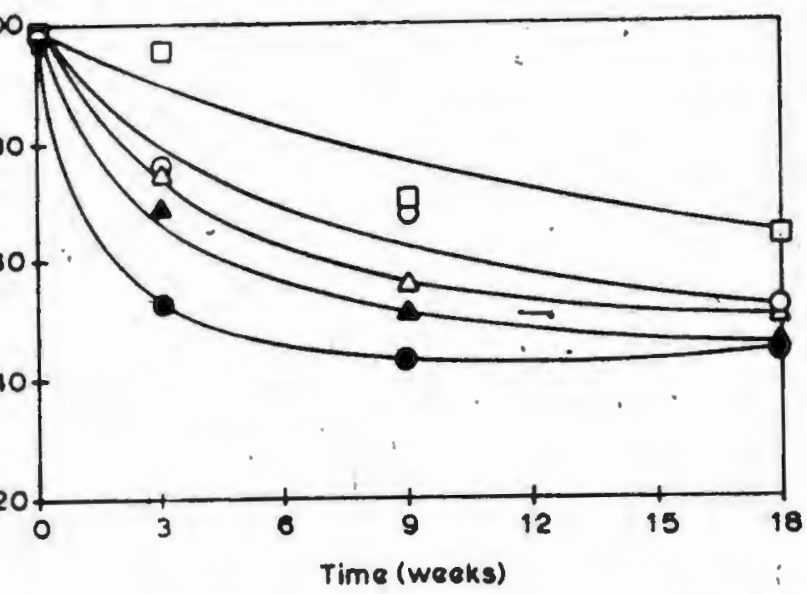

G. 5. Disappearance of diesel oil hydrocarbon ( $\mathrm{HC} ; 100 \mathrm{mg} \mathrm{g}$ oil $^{-1}$ ) from columns of loam soil. Symbols: $O^{;}$untreated loam - bioremediation-treated loam soil; $\square$, poisoned loam soil; $\Delta$, loam soil only; $\Delta$, bioremediation-treated (25\% of normal (izer) loan soil

lesel all. Diesel oil behaved quite similarly to heating oil 5 and Table 4), with a comparable or slightly longer -life. As in the case of heating oil, bioremediation reed diésel oil half-lives by $50 \%$ or more. Fertilization at nal and at $25 \%$ of the normal level had only a slight and zably not significant effect on the half-lives of diesel oil, cating that fertilizer can be applied at more cotservative $s$ without reducing the biodegradation efficiency. Tilling e increased oxygen availability and considerably shortthe half-lives compared with the oxygen availabjlity half-lives in the undisturbed soil columns, but it did not eve the same half-life reduction as it did in combination pH control and fertilization.

ur results show that the environmental persistence of ium distillate fuels increases in the following order: jet $>$ heating oil $>$ diesel oil. Bioremediation treatment itantially reduced the persistence of all three of these i. The tested incubation temperatures had largely preable effects on disappearance rates and indicated that in xerate regions, medium distillate contaminants of soil be reduced to essentially insignificant concentrations within one growing season. Inferior soil types and contamination levels up to the maximum holding capacities of the soils reduced disappearance rates only moderately and did not appear to preclude bioremediation in any of the tested situations.

The laboratory screening described in this report identified spills of medium fuel distillates as promising candidates for bigremediation. These fuels were subsequently seletted for larger-scale outdoor bioremediation studies (X. Wang and $\mathrm{R}$. Bartha, Soil Biol. Biochem., in press). The potential prob. lem of polyoyclic aromatic residues from diesel pil has been addressed separately. (X. Wang, X. Yu, and R. Bartha, Environ. Scl. Technol., in press), and the changes in the soil microbial community caused by fuel spills are the subject of an accompanying paper (9).

\section{ACKNOWLEDGMENT}

This study was supporied by New Jersey state funds.

\section{LITERATURE CITED}

1. Bartha, R. 1986. Biotechnology of petroleum pollutant biodegradation. Microb. Ecol. 12:15s-172.

2. Bartha, R., and 1. Bossert. 1984. The treatment and disposal of petroleum refinery wastes, p. 553-577. In R. M. Atlas (ed.), Petroleum microbiology. Macmillan, New York.

3. Bossert, I. and R. Barths. 1984. The fate of petroleum in the soil ecosystems, p. 135-473. In R. M. Atlas (ed.), Petroleum microbiology. Macmillan, New York.

4. Dibble, J. T., and R. Bartha. 1979. The effect of environmental parameters on the biodegradation of oil sludge. Appl. Environ. Microbiol! '37:729-739.

5. Gary, J. H., and G. E. Handwerk. 1984. Refinery products, p. S-15. In Petroleum refining: technology and economics, 2nd ed. Marcel Dekker, Inc., New York.

6. Praper, D., and R. Bartha. 1972. Preparation and processing of soil samples for biodegradation studies. Environ. Lett. 2:217224.

7. Pramer, D., and E. L. Schmidt. 1964. Experimental soil microbiology, p. 6-13. Burgess Publishing Co., Minneapolis.

8. Pye, V. I., and R. Patrick. 1983. Ground water contamination in the United States. Science 221:713-718.

9. Song, H.-G., and R. Bartha. 1990. Effects of jet fuel spills on the microbial community of soil. Appl. Environ. Microbiol. 56:646651 . 


\section{EH UPDATE}

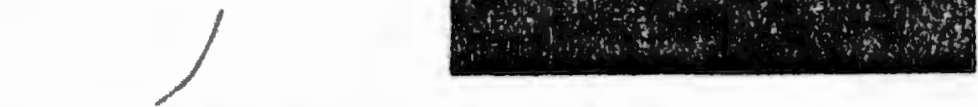

Journal of Environmental Health 53 (Jan/Feb, 1991):6. What's news in environmental health

\section{entiats dig deep for ate cleanup answers}

0. organiama living hundreda to thou. of fert benenth the eantern Wianh. ndemen may hold the apom to rienning art of the contamitation at the U.S art ment of Enera' Hanford Site and arran molluted with haz ardoun and' dinartive wanten. Microben in the urface environment may br able to anme of the wanten produred during y 50 yearm of nuclear materiale pro. ion at Hanford. iention a recently began drilling a derp hole on the Hanford Site to aparch for nirronmpic organiome. Thry expect arh $n$ depth of 350 feel and hope in "serantile" micro-oranninma which unite in a Jow-oxygen envirunment onmuming other materiale including rdman winatra

e drilling in sen of the U.S Drpar. ol Finerni Siuliourfare Science I'roif which rexearchern at the lacific intal Lalucaton; other DDE: Inbara and right unlverailien are we arching nnic aneverpi alcout nubalurtare or. ma Nultulle uperatea PNL bor I)OL: Il. lle mararchers already hase ahomn nome miernorganiuma can render crtain chemical compound harmleas. - One can neutralise potentially toxic ni. unten in croundwater while nimultannounly dentroying carbon tetrachloride, a car. cinogenic molvent uned extennively over the yeara at many induntrial facilitien.

Sisbeurfare mirm-organíms alno may play a part in the effort to clewn up nuclear * mer by creating biological barriere and allering the mobility or nolubility of rndioactive contaminant within the ground

Core anmples iaken from the Hanford Site will lee analyzed to help desielop futur ntraterien for nante cleanup. "Wie may be atble to manipulate the microbial pop. ulationa we expect to find to make them work faufer or connume apecific types of contaminanta," anya .lim Frederickaon. projecl m-manager.

\section{FDA issues guidelines for snte egR-handling}

Foodborne illnen due to Salmnnalla rn. erritis (S r.) contaminated erRo hno been increnming and apreading to many atenten an evidenced lyy recrint Centern for Dia. enar Conimol reporta. From Innungy 19,4: through Ortober 1949, 149 S r nutbreaka in the United Sintra cauned 6,604 illnenam

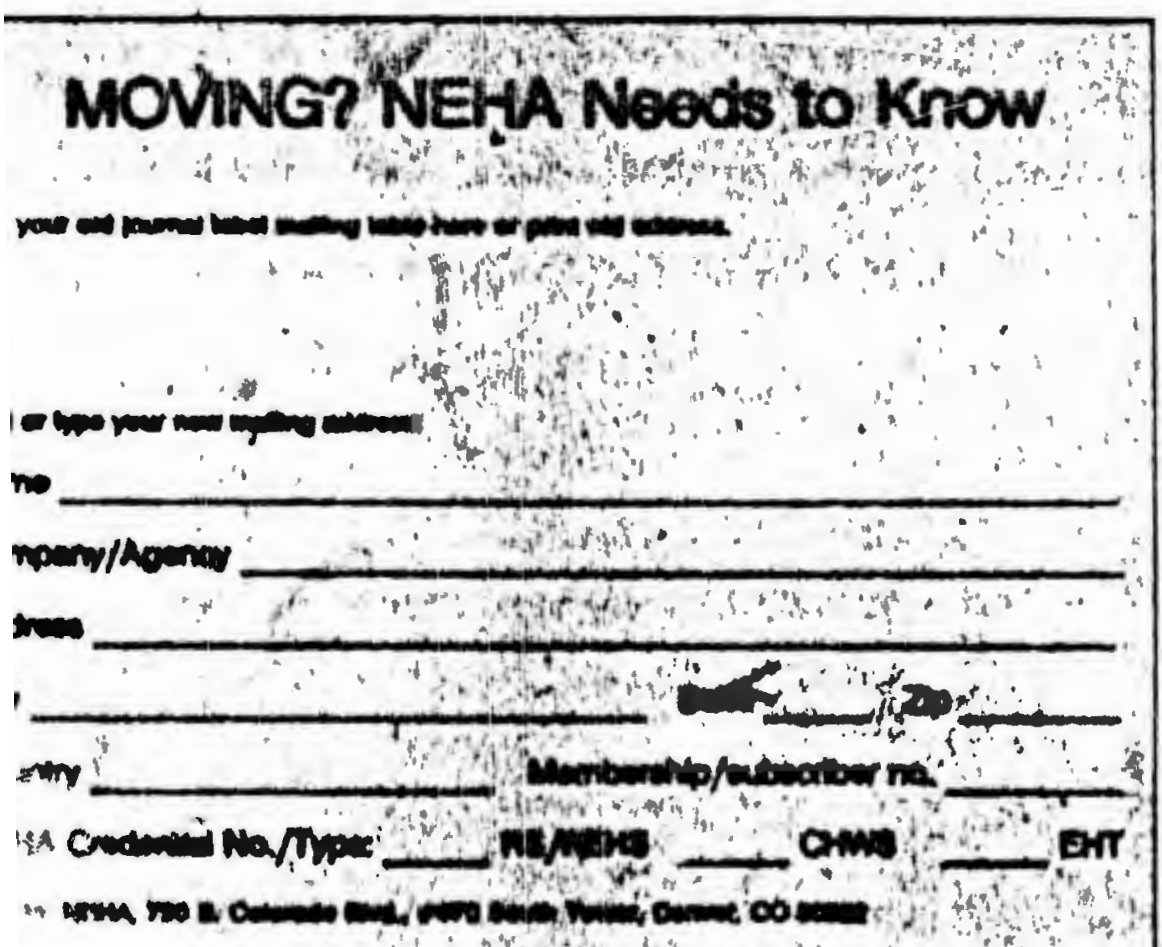

and 4.3 deatha. Morn than 30 outheraka were reported in the firat apyen momilis of 1990 .

C.DC'a atudies implicated refa as the likely nouren in 7.3\% of llor nulliernhe where a fond was identified. Time'irm peralure management of rzGa reprentonth has bern identified ha an importan? i. I I ponent of food anfety entrol rffoma. the

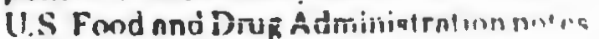

Moat rege do not conlans S r. For liner that do. it is nol yet knoun exactls hus or when the bacteria repreduce "hen ther nre present inaide nn intact rafe

In April 1990 the Conference for l'ims Protection recommended thal contrema about S.r be communicaled to nll hirallh and food protection agencira and to the food induatry. In reaponat, thr FI) A $\mathrm{R}$ : intrl Food Coder Interpretation had rritriy: nated ahell egra na a potentinilly $h$ if doun food and recommended the wh entablinhment operatora be reyuire I lo refrigerale and properly conk refe

The concepl of "potentinlly hainri! n/4 food" han been widely uard and unifer. ntood by tood rexulatorn for itrenc a linder FDA model roden nnd mingl " ne and local aintuten, remulntorn inn r.tile proper cooking and refrigeralion omls lior fooda no draignated. Conaumera i in remed with the Sr problem mnv b" in fnmiliar with the terminolokt. howerer.

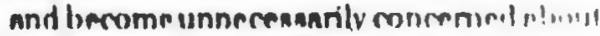
llie Reneral enfety of raka an fond

The FI)A, therefore, han nakndl lus nl

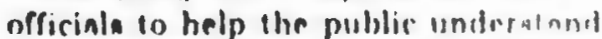
that the demigmation "pxotentinll, linen: doun fond'l nimply identifier foust. Por which limm/ermpernture mannerrwell in indicneal. Thene include n widr inrirts is perfectly ulmlmome nutritiona fomsly . . . n monly found in home refrigernlore. nile h na ment, poultry, finh dniry prodtul ta ant moked vegeintilen

\section{Internationnl garbnge trashing U.S. benches}

While Americans ure demonalrnimg: n

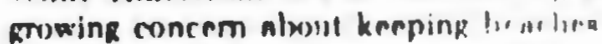
clenn. Iranh fmm otlore coumirion iml tinuen to foul the Uniled Siaten connal!men

A recent murvey, condurted by kimpl American Bhenutiful, Inc, in conjunctmon with a nntionwide beach cleanup pminet. rrponed that aome 124 fonk of I rash v na

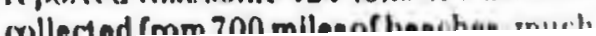




\section{NOTES}

${ }^{1}$ Brian J. Ford, Microbe Power (New York: Stein \& Day, $1976), 64$.

${ }^{2}$ Ronald Fletcher, Ph.D. of Affordable Technology,

Inc. Lecture notes from presentation at AGAC Environmental,

Inc. Woodbury, CT in September, 1990.

3 Ibid.

${ }^{4}$ Keith G. Angell, "After the Spill: The Cost of

Contaminant Cleanup," in the 1990 Management Sourcebook

Environmental Compliance ( Washington DC : Environmental

Publications, Inc., 1990), 71.

${ }^{5}$ Fletcher, Lecture notes.

${ }^{6}$ Ronald Fletcher, Ph.D., Environmental Bioremediation (Pittsburgh: Affordable Technology, Inc., 1990), 8.

7 Ibid., 5 .

${ }^{8}$ Fletcher, Lecture notes.

${ }^{9}$ Angell, 72 .

${ }^{10}$ Ibid.

11 Ford, 65 .

12 Ibid., 68 .

13 Robert D. Hof, "The Tiniest Toxic Avengers," Business Week, 04 June $1990,96$.

${ }^{14}$ Ford, 70 .

${ }^{15}$ K.A. Fackelmann, "Microbes Recruited in Valdez Cleanup," Science News, 135, 17 June 1989, 383.

${ }^{16}$ Ibid.

17 Mark Crawford, "Exxon Bets on Bugs in Alaska Cleanup," Science, 245, 18 August 1989, 704 .

${ }^{18}$ Stephan Budiansky and Russell Clemings, "Toxic Wastes? A Little Fungus May Help," U.S. News and World Report, 09 November $1987,85$.

$$
19 \text { Ford, } 69 .
$$


20 Walter H. Corson, ed., The Global Ecology Handbook (Boston: Beacon Press, 1990), 267.

$$
\begin{aligned}
& 21 \text { Ibid., } 5 . \\
& 22 \text { Ibid., } 265 .
\end{aligned}
$$

23 Richard A. Denison and John Raston, eds., Recycling and Incineration - Evaluating the Choices (Washington DC: Island Press, 1990), 236.

$$
\begin{aligned}
& 24 \text { Ibid., } 237 . \\
& 25 \text { Ibid., } 238 .
\end{aligned}
$$

${ }^{26}$ Louis Blumberg and Robert Gottlieb, War on Waste (Island Press, 1989), 28.

27 Jon R. Luoma, "Trash Can Realities," Audubon, March 1990,86 .

${ }^{28}$ McGraw - Hill, eds. Encyclopedia of Science and Technology (New York: McGraw - Hill, Inc., 1987), s.v. "Incineration," by Robert J. Bryan.

29 Jon Luoma, "Burn Garbage for Electricity - Yes, No, Maybe...." Audubon, March 1990, 96.

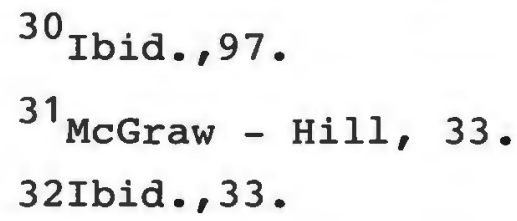

${ }^{33}$ Newsday, Rush to Burn: Solving America's Garbage Crisis? (Washington, D.C.: Island Press, 1989), 10.

${ }^{34}$ Ibid.

${ }^{35}$ Gregory Matzuk, "Energy Resource Recovery: A Technical Overview," American City and County, 106, January 1991, SW/RR 11.

$$
\begin{aligned}
& { }^{36} \text { Ibid. } \\
& { }^{37} \text { Newsday, } 11 . \\
& { }^{38} \text { Ibid. } \\
& { }^{39} \text { Ibid. }
\end{aligned}
$$




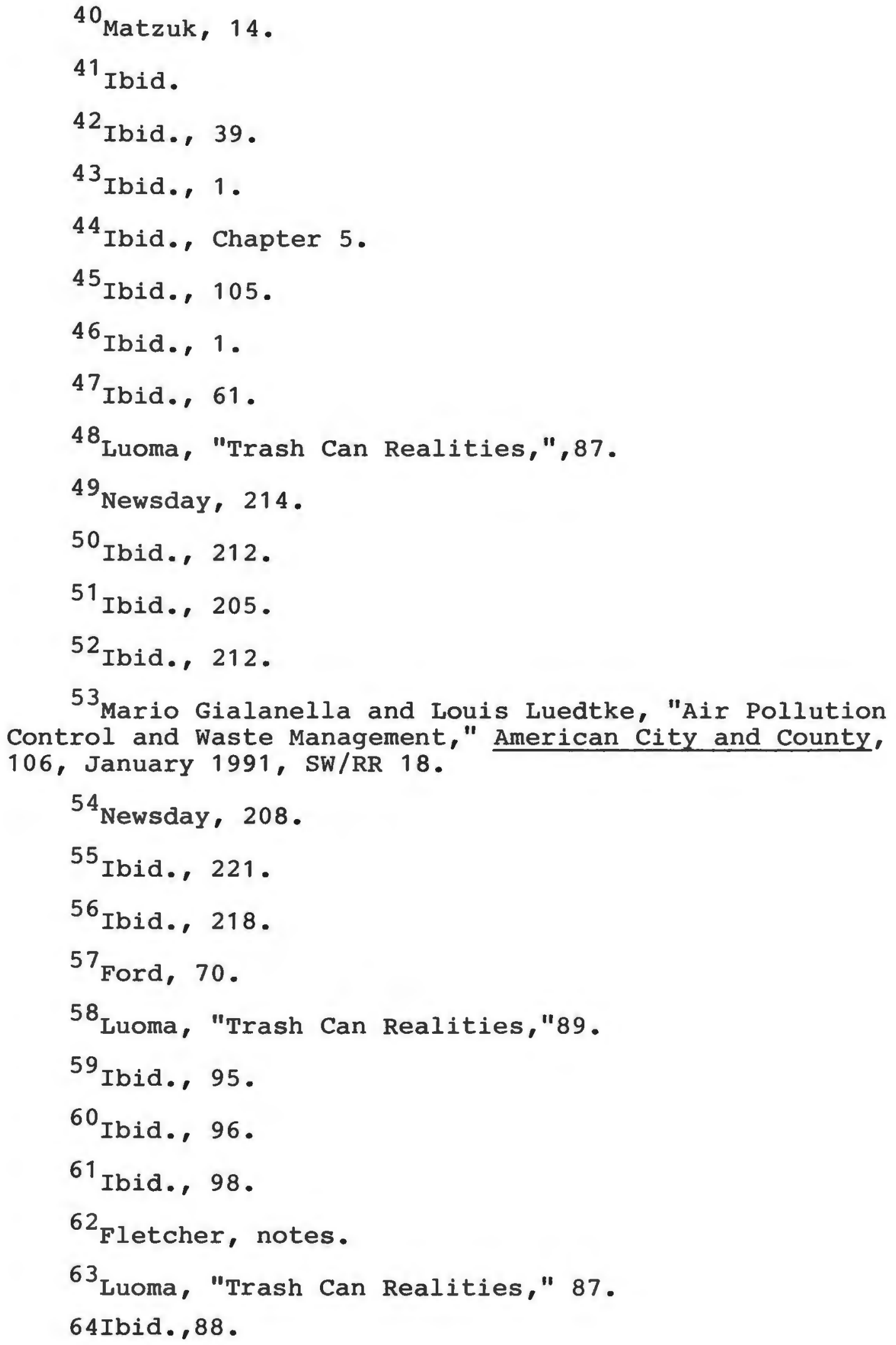


${ }^{65}$ Melinda Beck, "Buried Alive," Newsweek, 27 November 1989,70 .

${ }^{66}$ Sharon Begley, Hideto Takayama, and Mary Hager, "Teeing Off on Japans Garbage," Newsweek, 27 November 1989, 70 .

67 Ibid.

$68_{\text {Ibid. }}$

${ }^{69}$ Neil Seldman, "Waste Management: Mass Burn is Dying," Environment, 31 (September 1989): 43.

$70_{\text {Ibid. }}$

${ }^{71}$ Ibid., 44 . 


\section{BIBLIOGRAPHY}

Aelion, C. Marjorie and Paul M. Bradley. "Aerobic Biodegradation Potential of Subsurface Microorganisms from a Jet Fuel-Contaminated Aquifer." Applied and Environmental Microbiology 57 (January, 1991): 57-63.

Angell, Keith G. "After the Spill - The Cost of Contaminant cleanup." In The Management Sourcebook - Environmental Compliance, by Environmental Publications, Inc., 1990, 69-72.

"Bacteria Cuts the Cost of Cleaning up PCB's." New Science, 07 October 1989.

"Bacterial Armoury Joins Fight Against Alaskan spill." New Science, 10 June $1989,122$.

Baker, Ph.D, Jenifer M., Robert B. Clark, Ph.D., and Paul F. Kingston, Ph. D. "Environmental Recovery in Prince william Sound and The Gulf of Alaska" a supplement to the authors' scientific review, Natural Recovery of Cold Water Marine Environments After an oil spill, presented at the 13th Artic and Marine oilspill program technical seminar on 06 June 1990.

Beck, Melinda. "Buried Alive." Newsweek, 27 November 1989, $66-76$.

Begley, Sharon, Hideto Takayama, and Mary Hager. "Teeing off on Japan's Garbage." Newsweek, 27 November 1989, 70 .

Blumberg, Louis, and Robert Gottlieb. War on Waste. Island Press, 1989.

Budiansky, Stephan, and Russell Clemings. "Toxic Wastes? A Little Fungus May Help." U.S. News and World Report. 09 November $1987,85$.

Corson, Walter H., ed. The Global Ecology Handbook. Boston: Beacon Press, 1990.

Crawford, Mark. "Exxon Bets on Bugs in Alaska Cleanup." Science. 245,18 August 1989, 704 .

Crawford, Mark. "Bacteria Effective in Alaska Cleanup." Science. 1990, 1537.

Davis, John $\mathrm{W}$. and Constance L. Carpenter. "Aerobic Biodegradation of Vinyl Chloride in Groundwater Samples." Applied and Environmental Microbiology 56 (December, 1990): 3878-3880. 
Denison, Richard A. and John Raston, eds. Recycling and Incineration - Evaluating the Choices. Washington DC: Island Press, 1990.

Dixon, Bernard. Magnificant Microbes. New York: Atheneum, 1976 .

Fackelmann, K.A. "Microbes Recruited in Valdez Cleanup." Science News, 135, 17 June 1989, 383.

Fletcher, Ronald Ph.D. of Affordable Technology, Inc. Lecture Notes from presentation at AGAC Environmental, Inc. Woodbury, CT in September, 1990.

Fletcher, Ronald, Ph.D. Environmental Bioremediation. Pittsburgh: Affordable Technology, Inc., 1990.

Ford, Brian J. Microbe Power - Tomorrow's Revolution. New York: Stein \& Day, 1976.

Gialanella, Mario and Louis Luedtke. "Air Pollution Control and Waste Management." American City and County 106, January 1991, 17-22.

Hof, Robert D. "The Tiniest Toxic Avengers." Business Week, 04 June 1990, 96-98.

Luoma, Jon R. "Trash Can Realities." Audubon, March 1990, $86-97$.

Madsen, Eugene L., James L. Sinclair, and William C. Ghiorse. "In Situ Biodegradation: Microbiological Patterns in a Contaminated Aquifer." Science 252 (May 10, 1991) 830-833.

Matzuk, Gregory. "Energy Resource Recovery: A Technical Overview." American City and County 106, SWRR 10-14.

McGraw - Hill, eds. Encyclopedia of Science and Technology. New York: McGraw - Hill, Inc., 1987. S.v. "Incineration," by Robert J. Bryan.

Newsday. Rush to Burn: Solving America's Garbage Crisis?. Washington, D.C.: Island Press, 1989.

"Scientists Dig Deep for Waste Cleanup Answers." Journal of Environmental Health 53 (January/February, 1991):

Seldman, Neil. "Waste Management: Mass Burn is Dying." Environment 31 (September 1989): 42-4. 
Song, Hong-Gyu, Xiaoping Wang, and Richard Bartha. "Bioremediation Potential of Terrestrial Fuel Spills." Applied Environmental Microbiology 56 (March 1990): 652-56.

"Valdez 'Bugs' Chomp Away." Science News, 136, 15 July 1989,38 . 